\title{
PROCÉS INQUISITORIAL CONTRA EL CASTELLÀ D'AMPOSTA FRA PEDRO ROIÇ DE MOROS A LA CÚRIA PONTIFÍCIA DEL PAPA BENET XIII $(1414-1418)$
}

\author{
MN. JOSEP ALANYÀ I ROIG ${ }^{1}$
}

Data de recepció: març 2001

Data d'acceptació i versió final: gener 2002

Resum: A l'Arxiu de la Corona d'Aragó de Barcelona es conserva el procés original instruït per un tribunal de cardenals creat pel papa Benet XIII l'any 1414 per jutjar el Castellà d'Amposta, l'hospitaler Fra Pedro Roiç de Moros, acusat de crims greus - concubinat, bandositats, recepció d'apòstates, perjuri i fabricació de moneda falsa, mala administració dels béns de la Castellania, comissió d'excessos contra els seus vassalls, dilapidació de béns $\mathrm{i}$ abandó del patrimoni moble i immoble-, crims pels quals fou condemnat perdent la dignitat de Castellà. Roiç de Moros apel-là al Concili de Constança i a la Cort del papa Martí V. De res no li serví. Roiç de Moros va pagar cara la seva opció política a favor del comte Jaume d'Urgell i la seva oposició a Ferran d'Antequera i a la línia política del papa Luna.

El seguiment i l'anàlisi de tot el procés resulten molt atractius per la densitat humana que hi respira i l'interès de les informacions que dóna sobre les fortaleses, cases, graners, tresors i serveis de diferents llocs de la Castellania d'Amposta com ara Batea, Gandesa, Miravet, Ulldecona, Ascó i altres viles i llocs de la Ribera d'Ebre. I el procés té un interès històric peculiar sobretot perquè, en els protegonistes, actuacions i motivacions, hi resten lligats l'interregne successori de la Corona d'Aragó i els darrers moments del Cisma d'Occident.

Paraules clau: Cisma d'Occident, Concili de Constança, Interregne successori a la Corona d'Aragó, Martí l'Humà, Benet XIII, Ferran I, Orde de l'Hospital, Castellania d'Amposta, judici criminal.

Abstract: The Arxiu de la Corona d'Aragó in Barcelona houses the original commital proceedings instituted by a court of cardinals set up by pope Benedict XIII in the year

${ }^{1}$ Institut de Batxillerat "Infanta Isabel d'Aragó". Barcelona.

«Anuario de Estudios Medievales», 32/1 (2002), pp. 199-292.- ISSN 0066-5061. 
1414 and teh trial itself of the lord of Amposta, Fra Pedro Roiç de Moros, knight of the Order of St. John of Jerusalem, who had been charged with indictable offences-concubinage, robbery, housing apostates, oath breaking and counterfeiting money, mismanagement of the Castlery's assets, excesses against his vassals, wasteful use of assets, dereliction and property abandonment - of which he was found guilty, and thereafter sentenced to losing the dignity of his lordship. Roiç de Moros appealed to the Council of Constance as well as to pope Martin V. It would be to no avail. Roiç de Moros paid a very high price for choosing to support count Jaume d'Urgell and deciding to oppose Ferran d Antequera and the policies of pope Benedict XIII.

The follow up and analysis of the court's records are very interesting for their human variety and interesting informations about fortresses, houses, barns, treaures and services there were in different locations of the Castlery of Amposta, such as Batea, Gandesa, Miravet, Ulldecona, Ascó and other towns and villages along the Ribera đEbre. The whole criminal prosecution bears a very peculiar historic interest mainly because the protagonists, the court procedures, and their causes are the link between the Interregnum in the Aragonese Crown and the final days of the Western Schism.

Key-words: Western Schism, Council of Constance, Interregnum in the Aragonese Crown, Martin I king of Aragon, Benedict XIII pope in Avignon, Ferdinand I king of Aragon, Order of the knights of St. John of Jerusalem, Castlery of Amposta, Criminal prosecution.

\section{SUMARI}

1. L' “Originale processus".- 2. L'entrellat jurídic i polític del procés.- 3. Model o pauta per a l'interrogatori dels testimonis.- 4. La recepció de testimonis declarants.- 5. El memorial de visita de la Castellania.- 6. Declaracions dels testimonis.- 7. Fonts i bibliografia.- 8. Apèndix documental.

\section{L' “ORIGINALE PROCESSUS”}

Conservats a l'Arxiu de la Corona d'Aragó els plecs diversos, una part dels quals són documents de l' "originale processus" i d'altres són còpia, han estat reunits i ordenats per l'arxiver Jaume Riera i Sans segregant-los d'un fons antic de processos de l'Orde de Calatrava, entre els quals eren barrejats. Ara tots ells són reunits i guardats en el lligall 47 de la sèrie Processos en volum de la secció de Cancelleria Reial. Es tracta d'un procés redactat en paper de mida in folio i es troba entre els processos majors inclosos en la secció de Processos en volum de l'Arxiu. Ignorem de quina manera i per quin motiu els plecs del procés van arribar a l'Arxiu Reial de Barcelona en el seu dia. 
Cal advertir que no sabem de cert si els documents del procés hi són tots o n'hi ha hagut alguns que s'han perdut pel camí en el decurs dels segles; hi ha, però, indicis que no hi són tots i que alguns dels documents no són complets. Almenys hi trobo a faltar dos documents importants relatius a les comandes regides per Fra Gundisalvo de Funes que els comissionats del papa Benet XIII havien d'haver format per ordre pontifícia: 1) el document que havia de recollir els resultats de la visita a les comandes; i 2) el plec que havia de recollir les declaracions dels testimonis. I també hi falten dos inventaris esmentats en el procés: 1) l'inventari dels béns de la Castellania d'Amposta que van fer fer els visitadors; i 2) l'inventari dels béns existents en el castell de Miravet. Penso que les primeres dues peces judicials podien haver estat separades del procés en girar-se aquest exclusivament contra Fra Pedro Roiç de Moros. I els inventaris potser s'han perdut.

Un tercer inventari, el dels llibres cedits pel Castellà Roiç de Moros al Comte d'Urgell, Pere el Savi, va ser lliurat al secretari del Comte perquè el fes arribar a mans d'aquest. Ignorem si aquest tercer inventari va retornar al castell de Miravet o potser va romandre entre els llibres de la biblioteca del Comte d'Urgell passant posteriorment a mans de Ferran d'Antequera, qui va apoderar-se dels seus béns després de vèncer-lo en el setge de Balaguer el 1413.

El procés contra el Castellà d'Amposta Fra Pedro Roiç de Moros es troba repartit en diferents plecs que en el seu moment van ser numerats d'acord amb l'ordre físic en què eren integrats dins el conjunt de lligalls de processos de l'Orde de Calatrava, excepció feta del plec que conté les declaracions dels testimonis, que anomenaré Plec $\mathrm{A}$, el qual va passar desapercebut als arxivers de les darreries del segle XIX i primeries del XX i que només Jaume Riera ha sabut incorporar al conjunt de plecs del procés. Així s'explica la diversitat i la dispersió numèriques, sense ordre cronològic, que presenten.

\section{A. Numeració i ordenació antiga dels plecs}

L'ordre i la numeració que ara exposo, feta probablement entre els anys 1892 i 1911, no sabem per qui, durant les direccions de Manuel de Bofarull (1850-1892), Francesc de Bofarull (1893-1911) i Eduardo González Hurtebise (1911-1921), són anteriors a la reunió, ordenació i catalogació dels diversos plecs realitzades recentment per l'arxiver Jaume Riera i Sans en un 
sol lligall, el que duu el número 47 dels Processos en volum de la Cancelleria Reial. Els números dels plecs i llurs continguts, presentats en ordre numèric de menor a major, són els que segueixen:

\section{Plec $102 / 24$}

A. Butlla del papa Benet XIII destinada als seus cardenals, Joan, del títol de Sant Llorenç in Damaso, i Pere de Sant Àngel, membres del tribunal pontifici creat per a jutjar el Castellà d'Amposta, en què els comunica la comissió feta a Íñigo de Alfaro, preceptor de Ricla, i a Pascasio de Moralla o Morralla, prior de Montsó, hospitalers, per tal que puguin inquirir, rebre declaracions de testimonis i fer les visitacions oportunes i necessàries "super vita et moribus ac Religionis observantia dicti Petri nec non de regimine et administratione ipsius in eodem prioratu (Castellanie de Emposta) eiusque domibus et membris in spiritualibus et temporalibus". (fol.1) Sant Mateu, 5 de juliol de 1414 .

B. Confirmació papal solemne de la sentència dictada pels cardenals esmentats, signada i segellada pel papa Benet XIII a Sant Mateu el 10 de juliol de 1414. (fol. 2 r.v.)

\section{Plec $102 / 32$}

Joan Nicolau, en representació i com a procurador de Fra Pedro Roiç de Moros, compareix davant el tribunal de cardenals reclamant i protestant contra les comissions, inquisicions i visites realitzades contra el Castellà d'Amposta Roiç de Moros per ordre del papa. 26 folis.

\section{Plec $102 / 33$}

Manual de les investigacions i gestions realitzades pels nou compromissaris de Casp "in quadam aula Castri de Casp" a partir del dia 29 de març de 1412 "ad faciendam investigationem et publicationem Regis".

"Manuale negotiorum factorum per novem personas que facere debent noscionem, investigationem et publicationem Regis”. 18 folis. 
4. Plec $102 / 34$

A. Actes de la reunió dels diputats dels parlaments aragonès i català a Alcanyís. Hi ha afegit un document del rei Ferran I d'Antequera.

B. Actes de la reunió a Casp dels ambaixadors d'Aragó, València i Catalunya. 4 folis.

\section{Plec $105 / 5 \mathrm{~A}$}

Sumari del procés contra Fra Pedro Roiç de Moros, en què hom l'investiga i l'acusa de concubinat, de bandositats, de recepció d'apòstates, de mal govern de la Castellania amb negligència en castigar els vassalls, de perjuri i de fabricació de moneda falsa. 27 de juny de 1414. 15 folis.

\section{Plec $105 / 5 B$}

A. Sentència condemnatòria del Castellà d'Amposta Roiç de Moros promulgada pels cardenals de la Cúria Pontifícia del papa Benet XIII. 27 de juliol de 1415 i 11 de febrer de 1418. 10 folis.

B. Recursos primer i segon de Fra Pedro Roiç de Moros contra el procés incoat i contra la sentència promulgada. Abundants anotacions als marges relatives al text del recurs, escrites de mà d'un jurisperit assessor del tribunal pontifici o d'algun dels membres del tribunal. 2 folis.

C. Document notarial en què consten els deutes, pagaments i cobraments del Castellà Roiç de Moros. 2 folis.

D. Còpia notarial dels privilegis concedits a la Castellania d'Amposta per diversos monarques d'Aragó, Jaume I $(1233,1246)$, Alfons el Liberal (1288) i Jaume II $(1292,1323) .4$ folis.

E. Altra còpia notarial dels privilegis atorgats a la Castellania d'Amposta pel rei d'Aragó Jaume II (1323). 8 folis.

\section{Plec $105 / 5 C$}

Assentament de les quantitats dineràries rebudes per Fra Pedro Roiç de Moros de Fra Íñigo de Alfaro, regent la Castellania d'Amposta. 3 d'abril de 1413 i 13 d'abril de 1416. 4 folis. 


\section{Plec $106 / 38$}

Fra Gundisalvo de Funes, nomenat Castellà d'Amposta després de ser privat i desposseït de la Castellania Fra Pedro Roiç de Moros per sentència judicial, es defensa dels atacs d'aquest a la legitimitat del càrrec de Castellà, recentment assumit, esgrimint la gravetat de les causes que el tribunal pontifici havia considerat provades i acceptades contra Roiç de Moros, el seu antecessor: concubinat, dilapidació de béns de l'Orde de l'Hospital, perjuri i maltractaments als vassalls de la Castellania. 28 de novembre de 1417. 17 folis.

\section{Plec $106 / 40$}

A. Apel-lacions de Fra Pedro Roiç de Moros, desposseït ja de la Castellania d'Amposta, contra la sentència en virtut de la qual havia estat privat de la Castellania. 23 d'octubre de 1417 i 26 de juliol de 1418. 190 folis.

\section{l'arxiver Jaume Riera i Sans}

B. Numeració i ordre actual dels plecs del procés disposats per

1. Plec A. Aquest document, que he denominat Plec A, és el document que conté les declaracions dels testimonis rebuts en el procés obert contra Fra Pedro Roiç de Moros, Castellà d'Amposta. Any 1413. Aquest document, tot i ser una peça fonamental del procés i riquíssima en informació, fou ignorat, hom no va saber relacionar-lo amb el procés o va passar desapercebut als autors de la primera catalogació. Sortosament Riera i Sans l'ha posat al seu lloc incorporant-lo al lligall. Aquest mateix arxiver creu que el plec és una còpia de 1417. 173 folis.

2. Plec B. Sumari del procés contra Fra Pedro Roiç de Moros, Castellà d'Amposta. Any 1414. Segons Riera i Sans els plecs que el formen són còpia de l'any 1417. Els plecs que el formen són quatre:

a. "Summarium processus". 22 folis.

b. "Acta super Castellania Emposte, diocesis dertusensis, in partibus Hispaniarum". Any 1414. 14 folis. 15 folis.

c. "Summarium processus". Numeració antiga 105/5A. Any 1414. 
folis.

d. "Summarium processus". Numeració antiga 110/3. Any 1414. 15

3. Plec C. Minutes i trasllats de diverses peces del procés de revisió o apel·lació. Còpia de 1417 segons Riera i Sans. Conté els següents plecs:

a. Pautes de l'interrogatori als testimonis. Plec in quarto. 12 folis. Inclou un full de paper in folio intitulat "In causa Castellanie Emposte".

b. "Acta Reverendi Domini Gundissalvi de Funes, Castellani Prioratus Castellanie Emposte, dertusensis diocesis". Any 1417.

Numeració antiga 106/38. 17 folis.

c. 1. "Propositio per partem adversam facta". Any 1417.

Numeració antiga 136/5. 12 folis. Falta el foli 7 r.v. La foliació va del foli 36 r. al $42 \mathrm{v}$.

c. 2. "Sententia lata contra fratrem Petrum Roderici de Moros per cardinales super Castellania de Amposta". La foliació va del foli 43r. al 47r.

d. Un paper solt in folio que tracta de les pautes de defensa i revisió a seguir la part del Castellà d'Amposta. Foli 73 r.v.

e. "Memoriale et informatio per procuratorem Domini Castellani in causa sua". Folis 74 r. -79 v. 6 folis.

f. Dos papers de testificació solts in folio i sense data.

g. Una cèdula de paper in octavo: "Informatio de agendis in Avinione in causa de Emposta. Memoriale Domini Gasparis de Peruso, advocati Domini Castellani in causa Castellanie". Foli 1 r.v.

h. 1. "Sententia". Any 1417. "Sumario del proceso por el que se desposeyó a Fr. Pero Ruiz de Moros de la Castellanía de Amposta. Tortosa. Comisión: Éneco de Alfaro y Pascasio Moralla". Numeració antiga 105/5B. 10 folis.

h. 2. "Sigue el proceso contra Fr. Pero Ruiz de Moros. Comisión: Juan de San Lorenzo, Belenguer [...] y Pedro de Santángelo, cardenales". Numeració antiga 105/5B. 10 folis.

h. 3. "Asiento de las cantidades recibidas por Pero Ruiz de Moros de parte de Énego de Alfaro, regente de la Castellanía". Numeració antiga 105/5C. 4 folis.

i. Procuració de Fr. Pedro Ruiz de Moros, Castellà d'Amposta, davant la Cort Romana. Trasllat. Tortosa, 17 de febrer de 1417. Numeració antiga 106/3. 4 folis.

j. Procuració de Fr. Pedro Ruiz de Moros, Castellà d'Amposta, davant la Cort Romana. Numeració antiga 102/32. 27 folis. 
k. 1. Comissió feta pels cardenals de Benet XIII a les persones d'Íñigo de Alfaro, preceptor de Ricla, i Pascasio Moralla, prior de Montsó, per fer una investigació sobre Fra Pedro Ruiz de Moros. 3 de juny de 1414. Fol. 1 r.v.

k. 2. Confirmació de la sentència. 10 de juliol de 1414. Fol. 2 r.v.

k. 3. Sentència. 3 de juliol de 1414. 6 folis.

k. 4. "Allegationes iuris super facto Castellanie Emposte". 4 folis.

4. Plec D. Procés de la revisió o apel-lació al Concili de Constança i al papa Martí V. Anys 1417-1418. Numeració antiga 106/40. 190 folis.

\section{L'ENTRELLAT JURÍDIC I POLÍTIC DEL PROCÉS}

A la mort de Fra Martí de Lihori, a finals de l'any 1396, la Castellania d'Amposta era en una crisi política, que la vivesa de l'afer del Cisma d'Occident dissimulava i en frenava els efectes desastrosos, efectes que aviat es produirien, s'agreujarien i sortirien a la llum. Per a succeir Martí de Liori, el Gran Mestre de l'Orde de l'Hospital de Sant Joan va nomenar Castellà d'Amposta, el 26 de febrer de 1397, Fra Gundisalvo de Funes, que era comanador de Cantavieja, confirmat en la possessió d'aquesta comanda el 12 de març de 1383 per l'assemblea general de l'Orde reunida en capítol a Valence sur Rhône ${ }^{2}$.

L'any abans, però, del nomenament de Gundisalvo de Funes com a Castellà d'Amposta per l'Orde de l'Hospital, la reina Maria de Luna, el 5 d'octubre de 1396, de Barcelona estant, escrivia una carta al papa Benet XIII, en què li suplicava que, estant en perill de mort el Castellà d'Amposta Fra Martí de Lihori, quan vagués la Castellania tingués a bé "provehir d'aquella benignament e graciosa al frare P. Roiç de Moros, comenador de Castellot e loctinent de Castellà, com sia cavaller molt notable e entich en son orde..."3. I el 15 d'octubre de 1396, el rei Martí l'Humà escrivia al papa Benet XIII altra carta demanant-li que "en cas que vagàs la Castellania d'Amposta per cessum vel decessum de frare Martí de Lihori, plagués a la Vostra Santedat

\footnotetext{
${ }^{2}$ Arxiu de Malta, Liber Bullarum Mag., VII, fol. 4 v. Cfr. Delaville Le RoulX, Les hospitaliers à Rhodes jusqu'à la mort de Philibert de Naillac (1310-1421), p. 341, nota 1.

${ }^{3}$ Arxiu de la Corona d'Aragó (ACA), Cancelleria, reg. 2333, fol. 51 r.v.
} 
de la dita Castellania benignament e graciosa provehir al Religiós frare P. Roiç de Moros, comanador de Castellot e lochtinent de la dita Castellania"4.

Els documents abonen, doncs, que Roiç de Moros fou nomenat Castellà d'Amposta pel papa Benet XIII a petició del rei Martí I i de la reina Maria de Luna; i que Gundisalvo de Funes fou nomenat per al mateix càrrec i dignitat pel Gran Mestre i Orde de l'Hospital. Un dels dos nomenaments era il-legítim i, més encara, invàlid; i la il-legitimitat i invalidesa afectaven el nomenament papal perquè la col·lació dels priorats de l'Orde de Sant Joan era dret exclusiu del Gran Mestre i el papa no hi tenia cap dret. Per això, des del moment mateix dels respectius nomenaments hi hagué viva pugna entre Roiç de Moros i Funes sobre la legitimitat i validesa de la possessió de la Castellania.

L'any 1403, Funes apareix com a comanador de Cantavieja i d'Aliaga, just en el moment en què el Gran Mestre, Filibert de Naillac, defensant els drets de l'Orde i els de Funes, retenia sota la seva jurisdicció directa, tot eximint-les de la jurisdicció del Castellà d'Amposta nomenat pel papa, les dues comandes de Cantavieja i Aliaga. Aquesta decisió de Naillac ja li semblà bé a Funes, tant que la considerava un favor, i de fet era una mesura política que s'imposava atès que aquest, que veia com ocupava la Castellania un frare posat per Benet XIII, sentint-se'n ell desposseït quan n'era el legítim Castellà, no podia quedar sota la dependència personal i jurídica del seu competidor Roiç de Moros. El Gran Mestre així ho havia comprès i va voler posar-hi remei des de bon principi tot afavorint Funes contra Roiç de Moros.

Però una maniobra política de Funes perjudicà i molestà l'autoritat de Naillac. I és que Funes va tenir pressa a obtenir del papa Benet XIII la ratificació de la mesura presa pel Gran Mestre, gràcia que obtingué el 21 d'octubre de 1403, accentuant-se així les preferències de Funes pel papa d'Avinyó, contràries a les que mostrava el Gran Mestre de Rodes en l'afer del Cisma d'Occident. No ens ha d'estranyar pas que Gundisalvo de Funes, tan aviat com fou nomenat Castellà d'Amposta, abracés el partit dels seguidors i defensors del papa Benet XIII i de la seva legitimitat pontifícia, lligant així, estratègicament, a la legitimitat papal de Pedro de Luna la seva pròpia legitimitat com a Castellà d'Amposta.

${ }^{4}$ ACA, Cancelleria, reg. 2289, fol. 1 v. 
Quan el Gran Mestre i convent de Rodes, mal informats, l'any 1399, havien mantingut Funes en la possessió de la Castellania contra Pedro Roiç de Moros, considerat per Funes un usurpador, és clar que ignoraven l'opció política de Funes ${ }^{5}$. Però és clar també que defensaven els drets de l'Orde en el nomenament dels seus priors. Per això no els agradà gens el gest de Funes en acudir al papa Benet XIII perquè confirmés el seu nomenament de Castellà. Tota la força de legitimitat i validesa de la collació de dignitats de l'Orde radicava en el Gran Mestre i el Capítol de l'Orde. El Papa no hi tenia res a veure i cap dret no l'assistia.

Roiç de Moros fou cridat a Rodes davant el Gran Mestre i l'assemblea de frares i allí va exposar quina era la situació i, segons el seu parer, de quina part estava la legitimitat de la possessió de la Castellania d'Amposta. És una cosa estranya, i semblaria que els va convèncer perquè, el 12 de maig de 1400 , es va fer reconèixer la dignitat de Castellà d'Amposta $i$, de fet, va exercir-ne les funcions des de l'any 1400 al 1413 sense cap entrebanc ni oposició per part del Gran Mestre Naillac. Així consta a l'Arxiu de Malta ${ }^{6}$. Jo penso, però, que no els va convèncer de res. El reconeixement que va obtenir i l'actitud que envers ell va adoptar Filibert de Naillac no van ser, al meu parer, sinó una ficció estratègica i oportunista, una presa de posició política per tal de no oposar-se obertament al papa Benet XIII i desautoritzar-li públicament la injerència en els afers de l'Orde.

Com podem veure, doncs, el procés contra Fra Pedro Roiç de Moros es preparava ja de lluny sobre la base de la pugna d'ell i de Fra Gundisalvo de Funes per la possessió efectiva de la Castellania d'Amposta i la legitimitat jurídica dels drets que ambdós ostentaven i pretenien ostentar davant els seus vassalls i davant el Gran Mestre i convent de Rodes. Aquesta pugna ens fa entendre la constant oposició i fins i tot refús que al llarg de tot el procés manifesta Fra Roiç de Moros contra Fra Gundisalvo de Funes.

El que podria sorprendre és que el procés penal contra Roiç de Moros l'obrís el papa Benet XIII, el mateix que l'havia nomenat irregularment Castellà d'Amposta. Però la sorpresa es fon quan veiem l'actitud política de Roiç de Moros en l'interregne successori de la Corona d'Aragó i la seva

\footnotetext{
${ }^{5}$ Archivo General Central de Alcalá de Henares, lengua de Aragón, lligall 21, butlla original. Arxiu de Malta, Liber Bullarum Mag., XV, fols. 67 r.v.-68 r.v. Cfr. DELAVILLE LE ROULX, op. cit., p. 341, notes 1 i 2 .

${ }^{6}$ Arxiu de Malta, div. I, vol. 25. Lib. Bull. Mag., XXIV, fol. 250 r.
} 
parcialitat del cantó del Comte d'Urgell contra la posició i manipulacions polítiques de Benet XIII a favor de Ferran d'Antequera.

La Castellania d'Amposta era un gran territori jurisdiccional de l'Orde de l'Hospital que incloïa trenta comandes i un centenar de llocs i castells dins el regne d'Aragó i una franja de terra situada a la dreta del riu Ebre, dins el principat de Catalunya, amb les comandes i castells de Miravet, Ascò, Batea i l'Algars, Orta de Sant Joan, Vilalba dels Arcs i Ulldecona i una trentena de llocs i castells. La vila d'Amposta que donava nom a la Castellania havia estat comanda hospitalera fins que la vila fou recuperada, l'any 1280 , pel rei d'Aragó. El Castellà d'Amposta gaudia d'una dignitat, d'un poder jurisdiccional i d'una influència política importants sobretot des de que ostentà el càrrec Fra Joan Fernández de Heredia (1346-1377), posteriorment (1377-1396) Gran Mestre de Rodes. Però és que, a més, l'Orde de l'Hospital, amb la resta dels ordes militars, com ha escrit Pierre Bonneaud, "par l'importance de leurs domaines et le nombre de leurs sujets se plaçaient au premier rang des institutions signeuriales des royaumes de la Couronne et du principat de Catalogne" 7 .

La influència política la va fer valer el protagonista del procés que estudio, Fra Pedro Roiç de Moros $^{8}$, sobretot durant l'interregne successori de la Corona d'Aragó després de la mort del rei Martí l'Humà, el 31 de maig de 1410, i fins a l'elecció de Ferran d'Antequera. Influència política orientada en un sentit que, anys a venir, acabarà esdevenint un boomerang contra la persona del frare santjoanista i contra les atribucions i drets de Castellà d'Amposta de què gaudia. Perquè és cert que la seva posició partidària i la seva actitud i manipulacions polítiques en l'interregne, en els primers anys del regnat de Ferran d'Antequera i durant els darrers anys del Cisma d'Occident,

${ }^{7}$ Pierre BonNEAud, Le rôle politique des ordres militaires dans la Couronne d 'Aragon pendant l'interrègne de 1410 à 1412 à travers les Anales de Zurita, a "Aragón en la Edad Media XIV-XV", Homenaje a la profesora Carmen Orcástegui Gros, vol. I, p. 119. L'estudi de Pierre Bonneaud aporta una informació molt interessant sobre la participació dels ordes militars i dels seus dignataris més rellevants en la política de la Corona d'Aragó durant l'interregne de 1410 a 1412 i llurs influències en el desenvolupament dels fets successoris així com en els fets relatius al Cisma d'Occident en la seva etapa final.

${ }^{8} \mathrm{El}$ personatge és anomenat de diferents maneres en els diversos textos contemporanis on apareix 1 en els dels autors que s'hi han referit tot depenent de la llengua en què són escrits. Així, és anomenat Petrus Roderici de Moros en els textos llatins; Pero o Pedro Roiç de Moros en els textos castellans o catalans de l'època; també Pero o Pedro Ruiz de Moros i Pedro Rodrigo de Moros en altres textos castellans i en els Anales de Jerónimo ZURITA. En el present estudi respectaré la forma nominal dels textos castellans o catalans de l'època Pedro Roiç de Moros. 
van ser causa, i no secundària, del procés judicial a què va ser sotmès pel tribunal creat pel papa Benet XIII i de la deposició de la dignitat de Castellà d'Amposta, que dolorosament hagué de suportar.

El procés fou iniciat l'any 1413, - "Pontificatus nostri anno decimonono"-, data de les lletres apostòliques de Benet XIII ordenant la informació i recollida de testimoniatges sobre la vida, costums i gestió de Roiç de Moros a la Castellania d'Amposta, això és, sis mesos i vint dies després de la proclamació de Ferran d'Antequera com a monarca de la Corona d'Aragó.

Cal imaginar-se el greu disgust i la decepció de Benet XIII, el papa que el va elevar a la dignitat de Castellà d'Amposta a precs del rei Martí i de la reina Maria de Luna, en veure l'actitud i capteniment humans i polítics de Roiç de Moros, i comprendrem que en el procés iniciat pel Papa no hi hagi només voluntat de fer justícia sinó també un cert afany de venjança contra una persona desagraïda i gens fidel, com ara demostraré.

En efecte, pel que fa a la situació política creada per la mort de Martí l'Humà sense deixar descendència directa ni designat o recomanat un successor al tron, cal dir que el Castellà d'Amposta, Fra Pedro Roiç de Moros, va prendre partit pel Comte d'Urgell i va defensar els seus drets a la successió reial al costat de l'aragonès Antonio de Luna, també partidari del Comte i considerat pels partidaris de Ferran d'Antequera, també per Zurita, activista i cabdill de totes les empreses militars de Jaume d'Urgell dins el regne d'Aragó.

Durant els primers mesos de l'interregne Roiç de Moros donà acolliment al Comte dins la vila de La Almunia de Doña Godina, lloc de l'Orde de l'Hospital i de la Castellania d'Amposta perquè, instal-lat allí, pogués exercir els poders de pretenent legítim a la Corona que no podia fer efectius a la ciutat de Saragossa, controlada pels Urrea, contraris al Comte d'Urgell, els quals obtenien el suport polític i militar del governador del regne, Gil Roiç de Lihori, del justícia d'Aragó, Juan Ximénez Cerdán, i de l'arquebisbe, García Fernández de Heredia. L'acolliment, però, no durà gaire perquè, obligat per les pressions del parlament de Barcelona que exigia igualtat d'oportunitats i de condicions per a tots els pretendents a la Corona, Jaume d'Urgell hagué de deixar el seu lloc segur i, amb ell, tots els avantatges que hi tenia.

Zurita ens informa que Roiç de Moros, el mes de febrer de 1411, en companyia d'Antonio de Luna, va acudir al parlament dels aragonesos reunit 
a Calataiud, vila controlada pels Urrea, on ambdós, tot i presentar-se com a diputats del regne, van ser mal rebuts i d'on van ser expulsats pel governador i el justícia d'Aragó, presidents de l'assemblea parlamentària, tot prohibint-los de tornar fins que no hi hagués tornat l'arquebisbe de Saragossa. L'arquebisbe de Saragossa, òbviament, no hi podia tornar a Calataiud; feia molt poc que havia estat mort violentament i Antonio de Luna era l'inculpat del crim sacríleg, per la qual cosa havia estat excomunicat.

L'arquebisbe García Fernández de Heredia era nebot del Gran Castellà d'Amposta i després Gran Mestre de Rodes Fra Joan Fernández de Heredia. Fervent partidari del papa Benet XIII, amic íntim del rei Joan I i contrari al nomenament del Comte d'Urgell com a governador general del regne després de la mort de Martí l'Humà, va assumir-ne ell mateix la capitania general. L'arquebisbe, que mantingué sempre l'oposició a la successió al tron del Comte d'Urgell, enemistant-se per això amb Antonio de Luna, partidari del Comte, fou assassinat per aquest noble aragonès a $\mathrm{La}$ Almunia de Doña Godina quan l'arquebisbe tornava del parlament de Calataiud. La Almunia era vila de la Castellania d'Amposta i, per tant, de la jurisdicció de Roiç de Moros. En l'assassinat tothom hi va veure o hi va sospitar la col-laboració i acord del Castellà d'Amposta tot i que aquest no era físicament en companyia d'Antonio de Luna en el moment de perpetrar-se el crim. Roiç de Moros va seguir donant suport i protecció moral i física al noble aragonès, i també refugi dins els territoris i castells de la seva jurisdicció sobretot quan aquest es va veure amenaçat per l'entrada de soldats castellans al regne d'Aragó en defensa de les pretensions i drets de Ferran d'Antequera.

La mort de l'arquebisbe de Saragossa fou causa del procés eclesiàstic obert per ordre del papa Benet XIII contra Antonio de Luna i els seus còmplices materials en l'assassinat sacríleg, tots els quals van ser excomunicats. Pedro Roiç de Moros, caigut en desgràcia als ulls del Papa i considerat còmplice moral del crim comès per Antonio de Luna, no va escapar a la justícia pontifícia i fou inclòs també en el procés juntament amb el comanador de Montalbán, Fra Pedro Fernández de Híjar, de l'Orde de Santiago. Fou aquest el primer procés obert contra Fra Pedro Roiç de Moros, que no acabà sentenciant-se perquè el vicari general de Saragossa es va reservar la sentència.

El Castellà d'Amposta era ja, doncs, en el punt de mira de Benet XIII i no trigaria a experimentar en la seva pròpia persona la persecució dura i les 
conseqüències negatives de la seva actitud i posició política favorable a Jaume d'Urgell, contrària, doncs, a Ferran d'Antequera, qui era el preferit de Benet XIII per a succeir el rei Martí.

Per als partidaris del Trastàmara aspirant a la Corona d'Aragó la figura del Castellà d'Amposta resultava molesta, les seves maniobres polítiques eren mal vistes i calia desconfiar totalment d'ell tant més quant que la seva influència era gran. Així, doncs, ja no tenia el favor del Papa ni el del ja imminent futur rei d'Aragó, però tampoc la confiança dels parlamentaris del Principat de Catalunya, reunits a Tortosa, la dels valencians, reunits a Vinaròs, ni la dels aragonesos, reunits a Alcanyís. Una prova de la desconfiança que inspirava la persona i l'actitud de Roiç de Moros la tenim en el fet que, després d'haver estat escollida la vila de Casp, de la Castellania d'Amposta, com a lloc de reunió dels nou compromissaris, l'Orde de l'Hospital, desconfiant de Roiç de Moros, demanà al papa Benet XIII d'assegurar i garantir durant el temps de reunió dels electors la seva soberania i jurisdicció sobre la vila perquè aquesta era sota la jurisdicció del Castellà d'Amposta, i aquest era aliat destacat del Comte Jaume d'Urgell. I el Papa, amb un decret, va sostreure la vila de la jurisdicció del Castellà d'Amposta. La custòdia de la vila i del castell va quedar a mans dels capitans Asbert Ça Trilla, Martín Martínez de Marcilla i Pere Sabata i dels alcaids Domingo Lanaja, Guillem Çaera i Ramon Fivaller.

L'opció política de Roiç de Moros era la més desfavorable i cada cop es veia més clar que anava abocada al fracàs. No sabem quines raons i quins motius el van moure a prendre el partit del Comte d'Urgell, però no creiem que fos un error de càlcul, que sempre hauria estat a temps de corregir, sinó més bé una actitud de fidelitat al casal d'Urgell, una convicció ferma de la legitimitat dels drets de Jaume a la Corona i la coherència personal que el féu estar sempre al costat dels seus amics. Per les declaracions dels testimonis del procés sabem que el frare hospitaler tenia amistat i relacions personals amb el Comte Jaume com les havia tingut amb el seu pare, Pere II d'Urgell, a qui, segons declaracions testificals del procés, havia deixat en préstec una vuitantena de llibres de la biblioteca del Castell de Miravet.

En l'interregne, tota la realitat del procés de successió a la Corona d'Aragó i les seves circumstàncies, múltiples i complexes, xocaven amb la manera d'actuar del Castellà d'Amposta. Pedro Roiç de Moros va reservar-se l'àmbit de l'acció política, sense excloure la militar, creient que disposava d'un tauler d'escacs a la seva mida i que la seva capacitat de maniobra, això 
és, de joc, li permetria portar la partida al seu favor i acabar-la amb tots els avantatges. Però cada cop hi havia més distància entre els fets i llur evolució, entre l'escaquer, les regles del joc i les posicions que adoptaven les peces marcades pel senyal dels Trastàmara i les posicions de les peces marcades pel senyal d'Urgell, portades inevitablement a un final advers, a l'escac i mat del Comte, amb l'eliminació, prèvia, concomitant o posterior, dels seus partidaris, un d'ells, d'entre els principals, Fra Pedro Roiç de Moros.

El Castellà d'Amposta i Antonio de Luna, no acceptant el fet de no haver estat convocats al parlament dels diputats aragonesos reunit a Alcanyís, essent-ne tots dos diputats de ple dret, perquè el segon havia estat excomunicat i el Castellà era en procés de ser excomunicat arran de l'assassinat de l'arquebisbe de Saragossa, van anar units un cop més pel seu compte i van convocar un parlament aragonès paral·lel a Mequinensa, lloc en poder de Ramon Guillem de Montcada, nebot d'Antonio de Luna. El Castellà d'Amposta, que va presidir l'assemblea, era l'únic eclesiàstic assistent. Prenent una actitud legalista, va enviar una delegació al parlament dels catalans reunit a Tortosa que els proposés de no fer tractes amb el parlament aragonès d'Alcanyís, que ell considerava irregularment convocat i reunit, i es va oferir a establir i pactar amb els representants catalans i valencians les condicions de la declaració de successió al tron del rei Martí. Més encara, com escriu Pierre Bonneaud seguint Zurita, "dans un dernier et inutile contrefeu, Pedro Ruiz de Moros, président de l'assemblée de Mequinenza, mit en demeure le parlement de Tortosa d'envoyer des délégués à cette assemblée pour désigner des électeurs et un lieu d'élection, menaçant de procéder à la désignation du successeur de Martin Ier de manière unilaterale s'il n'obtenait pas satisfaction" .

Pedro Roiç de Moros no tenia en la seva posició política l'acompanyament o, si més no, el seguiment dels frares de l'Orde de l'Hospital, ni tan sols dels qui eren sota les seves ordres directes dins la pròpia Castellania d'Amposta, dels quals, com ho veurem per les declaracions dels testimonis del procés, desconfiava; i si entre els frares n'hi havia alguns de destacats, com Fra Íñigo d'Alfaro o Fra Gundisalvo de Funes, aquests eren partidaris de Ferran d'Antequera o almenys no eren partidaris del Comte d’Urgell; i Fra Pedro Fernández de Híjar, comanador de Montalbán, de

${ }^{9}$ BONNEAUd, op. cit., p.131. 
l'Orde de Santiago, qui li havia fet costat en defensa dels drets del Comte d'Urgell, el deixava sol en integrar-se al parlament d'Alcanyís. Així, doncs, podem dir que Roiç de Moros, com a dignatari eclesiàstic, fou un solitari, lleial i legalista, convençut i coherent, fidel fins a la fi a la causa del Comte d'Urgell, però a qui la història girà l'esquena i per això va acabar els dies de la seva vida en el més profund fracàs polític i personal. Un excel-lent seguiment del personatge i una fonda i precisa interpretació dels seus actes per part de Bonneaud ens ha proporcionat molta llum sobre el capteniment polític del Castellà d'Amposta en l'interregne successori i els primers dies del regnat de Ferran d'Antequera:

L'attitude du castellán de Amposta qui avait choisi le "mauvais camp" n'en fût pas moins parfaitement légaliste. Son soutien au comte d'Urgel s'appuyait sur la légitimité des pouvoirs que Martin Ier avait contié à ce dernier, d'abord comme lieutenant général puis comme gouverneur général de la Couronne. En fait ces nominations avaient été repoussées par la force par le clan des Urrea dans un soulèvement qui entraina la mort de plusieurs personnes à Saragosse. Le castellán pouvait donc s'estimer en droit, sinon dans le devoir, d'accueillir le comte dans ses seigneuries. Par la suite, son action privilègia le légalisme, la négociation et la participation à des instances collectives de décision, qu'il s'agisse de sa présence au parlement de Calatayud, du rappel de sa fonction de Diputado du royaume d'Aragon pour réunir et présider l'assemblée de Mequinenza, ou de ses interventions auprès du parlement catalan de Tortosa oú il avait désigné un procureur pour le représenter. Le 19 Juin 1411 il écrivait à ce parlement pour l'informer des désordres dans lesquels se trouve le royaume d'Aragon et des grands dangers qui menacent du fait des manoeuvres d'une faction dominant plusieurs villes et de la difticulté à réunir un parlement légitime en Aragon. Il s'adresse à nouveau le 28 Août à cette même instance au sujet des troubles d'Albarracin, oú le fills du gouverneur d'Aragon assiège le chateau et demande l'aide des Catalans pour rétablir la situation et les mettre également en garde contre la réunion, à ses yeux illégale, du parlement aragonais d'Alcañiz"1".

Pierre Bonneaud creu així mateix, seguint les notícies que ens dóna Zurita, que Fra Pedro Roiç de Moros s'implicà en l'afer polític de la successió a la Corona d'Aragó amb mitjans també polítics i només polítics, de manera que diu que en cap ocasió se'l troba emprant mitjans militars o cooperant físicament a accions militars concretes, ni tan sols en l'assassinat

"Ibidem, p. 133. 
de l'arquebisbe de Saragossa. És cert que en aquest fet només hi intervingueren Antonio de Luna i els seus còmplices i fautors; és cert que el Castellà d'Amposta mantingué el seu suport "post factum" al noble aragonès i li donà refugi dins els territoris de la seva jurisdicció, com ho féu també dins la seva pròpia el comanador de Montalbán, quan el de Luna era amenaçat per les primeres tropes castellanes que havien entrat a Aragó per assegurar una posició de força favorable als interessos del pretendent Trastàmara. Com afirma Bonneaud, "en face au développement des luttes armées, le castellán apparut comme militairement inactif. Il demeura dans son château d'Azcó alors que son parent Juan Ruiz de Moros se trouvait encerclé par le clan Urrea et par des troupes castillanes au château d'Albarracín. Le castellán fut appelé à la rescousse mais il "n'osa pas" quitter sa forteresse dont la défense était excellente" ". Zurita diu que Juan Ruiz de Moros tenia l'esperança de rebre el socors militar del Comte d'Urgell o almenys del Castellà d'Amposta, qui des dels castells de la Castellania i de les comandes més properes podia donar-li fàcilment ajuda. Roiç de Moros no hauria fet un pas amb les armes a la mà i hauria seguit mantenint-se dins l'àmbit de l'estricta activitat política.

Bonneaud, comparant les activitats de Fra Pedro Roiç de Moros i d'Antonio de Luna, arriba a aquesta conclusió:

Il semble que l'on assiste à un partage des rôles entre le castellán Pedro Ruiz
de Moros et le comte Antonio de Luna, le premier ayant recours à la
négociation et le second à la force des armes dans la défense de la même
cause. En effet, malgré la vocation militaire des Ordres, il n'apparaît aucun
indice de l'intervention du castellán dans les combats qui opposaient les
clans. L'attitude de Pedro Ruiz de Moros semble bien avoir été de refuser
obstinément toute compromission avec la violence, qu'il s'agisse de
l'assassinat commis par Antonio de Luna, du refus de porter secours à son
parent et à son propre camp assiégés à Albarracín, ou de son repli dans son
château de Miravet sans prêter main forte à la rebellion du comte d'Urgel et
d'Antonio de Luna après la décision de Caspe'.2.

Cal dir, però, que aquesta opinió prudent de Zurita, seguida per Bonneaud, és desmentida per declaracions d'alguns testimonis del procés.

"Ibidem, p. 127.

12Ibidem, p. 133. 
Ja he dit que en la posició política a favor dels drets del Comte Jaume d'Urgell Fra Roiç de Moros no era acompanyat pels frares del seu orde i ell no es fiava d'aquests, per la qual cosa, en els moments crítics, encomanava la responsabilitat dels castells a membres de la seva família i molt especialment als seus fills. Però encara més, frares hospitalers de prestigi i d'influència, considerats i ben vistos davant la cort papal de Benet XIII i davant els parlamentaris que orientaren els passos cap a l'elecció de Ferran d'Antequera, se situaven a la riba política oposada a la seva. Aquests frares, ja esmentats, eren Fra Íñigo de Alfaro, comanador de Ricla, i Fra Gundisalvo de Funes; i, en el cas concret de Gundisalvo de Funes, tenim fonament per pensar que les diferències entre ell i Roiç de Moros eren personals, fins i tot d'enemistat agra per raó de la contenció mútua per la Castellania d'Amposta, i no solament polítiques.

Fra Íñigo de Alfaro, a una banda, va cooperar amb Guillem Ramon de Cervelló, castlà del castell d'Alcanyís, i amb Joan de Luna, a qui reemplaçà, a garantir la seguretat de la vila d'Alcanyís i dels seus accessos viaris mentre s'hi celebrava la reunió del parlament aragonès, amenaçat per l'aixecament armat que hauria intentat d'ordenar el Comte d'Urgell dins el regne d'Aragó en qualitat de governador general. Fra Pedro Roiç de Moros, a l'altra banda, marxava a Mequinensa amb Antonio de Luna per reunir i presidir un parlament paral-lel, el parlament dels aragonesos partidaris del Comte d'Urgell. Quan va iniciar-se el procés papal contra Roiç de Moros, aquest és a una banda, la del processat, i Fra Íñigo de Alfaro és a l'altra, a la dels qui han obert el procés, puix li és encarregada, juntament amb Fra Pascasi de Morralla, prior de Sant Joan de l'Hospital de Montsó, la tasca de fer visitació i inquisició "in dicto domino fratre Petro, Castellano, et suis castris seu cameris ac locis dicte Castellanie”. Íñigo d'Alfaro, que havia estat lloctinent del draper de l'Orde, havia comandat a Esmirna una guarnició de 200 cavallers. El 3 d'abril de 1427, essent comanador d'Aliaga, comanda en què va succeir Gundisalvo de Funes, Fra İñigo es trobava malalt de gravetat i l'Orde va designar-ne un administrador; però la malaltia va perllongar-se i, el 16 d'agost de 1434, encara preocupava el Gran Mestre. La darrera menció d'Alfaro és del dia 28 de març de $1435^{13}$.

${ }^{13}$ DELAVILle Le RoulX, op. cit., p. 284 , nota 2. Arxiu de Malta, Liber bullarum Mag., XXXII, fol. 80; XXXVI, fols. 158 i 165 . 
És clar que el tribunal format pel papa Benet XIII per judicar, sentenciar i condemnar Roiç de Moros volia assegurar-se una inquisició i una visitació amb garanties d'eficàcia i útils als interessos papals i reials $i$, per això, per inquirir sobre la seva vida, costums, afers, observança dels deures religiosos i govern de la Castellania d'Amposta, no va trobar una altra persona més indicada que Íñigo de Alfaro, el frare hospitaler que sempre havia estat a l'altra banda, en l'oposició política a Roiç de Moros. De l'opció política del prior de Montsó no en tenim notícia, però, veient les intencions de Benet XIII d'anorrear Roiç de Moros, cal pensar que Fra Pascasi de Morralla compartia amb Íñigo de Alfaro opcions, actituds, conviccions i fidelitats al Papa Luna i a Ferran d'Antequera. Sabem per Zurita que Fra Ínigo de Alfaro era davant l'església de Casp el dia 28 de juliol de 1412 en l'acte de lectura pública de la sentència dels nou compromissaris, en virtut de la qual s'instal-lava en la Corona d'Aragó la dinastia castellana dels Trastàmara. I fou també ell un dels personatges escollits com a ambaixadors per anar a trobar el nou monarca, Ferran d'Antequera, informar-lo oficialment de la declaració successòria i retre-li l'homenatge preceptiu.

Fra Gundisalvo de Funes ocupà la dignitat de Gran Prior de Catalunya l'any 1411, després de la mort, l'any 1409, del Prior Des Pomer, i transcorreguts, per tant, dos anys sense cobrir l'Orde de l'Hospital aquest càrrec, les funcions del qual van assumir i complir, en els moments delicats de l'interregne successori, els lloctinents del Prior, Fra Ferran de Siscar i Fra Galceran Sarroca. De Funes va representar sempre l'oposició política i també personal a la figura humana de Pedro Roiç de Moros i a les posicions, actituds i pretensions d'aquest. Si De Funes era del costat de Benet XIII i de Ferran d'Antequera, Roiç de Moros era del costat del Papa de Roma, del Concili de Constança, de Martí V, i del Comte Jaume d'Urgell. I, sobre aquest rerefons, la pugna més forta van tenir-la tots dos, com es recull en el procés que estudio, en la pretensió de legitimitat i possessió real de la Castellania d'Amposta. El posicionament de De Funes explica que el procés iniciat pel Papa Luna, orientat de bon principi a inquirir bilinealment sobre Roiç de Moros i la Castellania d'Amposta i sobre Gundisalvo de Funes i les comandes de Cantavella i Aliaga, derivés unilinealment en un procés, judici i sentència exclusius contra Roiç de Moros.

Tot acabaria funestament i definitiva per a Roiç de Moros arran del procés criminal iniciat pel papa Benet XIII contra la seva persona i la seva governació quan li va ser arrabassada la Castellania i la dignitat de Castellà 
amb tots els seus drets jurisdiccionals i econòmics, acabant els seus dies reclòs com un senzill frare, més presoner que altra cosa, dins el castell de Miravet, que poc abans havia estat la fortalesa del seu senyoratge. Tot, però, havia començat a acabar l'any 1411, en declinar la seva estrella per causa de la seva adscripció al partit de Jaume d'Urgell i la seva col-laboració política i militar ${ }^{1+}$ a les accions del comte Antonio de Luna, motiu pel qual la Castellania d'Amposta va ser lliurada en administració a Fra Íñigo de Alfaro. La persona de Roiç de Moros no era grata al pretendent castellà Ferran d'Antequera. Tampoc a Benet XIII. Sis mesos i vint dies després de la proclamació de Casp se li obria el procés.

Gundisalvo de Funes el va succeir al capdavant de la Castellania d'Amposta. Sabem per la documentació de l'Arxiu de Malta ${ }^{15}$ que a partir de l'any 1416 l'autoritat i la legitimitat de Funes com a Castellà d'Amposta foren admeses pel Gran Mestre de l'Orde de Sant Joan, en companyia del qual, l'any 1409, Gundisalvo de Funes havia vingut a Occident, "ce qui est l'indice d'étroites relations d'amitié", diu Delaville le Roulx ${ }^{16}$.

Pedro Roiç de Moros i Gundisalvo de Funes, en la contenció pels drets de possessió de la Castellania, van recórrer a la Santa Seu i llurs reclamacions van anar a parar al cardenal del títol dels Sants Pere i Marcel·lí, Àngel Barbadigo, bisbe de Verona; però aquesta evocació i recurs davant la Santa Seu eren contraris als estatuts de l'Orde de l'Hospital. Ni la cúria de Benet XIII ni el Concili de Constança n'havien considerat la irregularitat i només el nou papa elegit en el si del concili, Martí $\mathrm{V}$, la va reconèixer el

${ }^{14}$ Pierre Bonneaud, seguint els Anales de Zurita, creu que el Castellà Roiç de Moros no havia intervingut de manera armada en les lluites de l'Interregne i només hauria actuat políticament com a negociador en la defensa de la causa del Comte Jaume d'Urgell "Il semble que l'on assiste à un partage des rôles entre le castellán Pedro Ruiz de Moros et le comte Antonio de Luna, le premier ayant recours à la négotiation et le second à la force des armes dans la défense de la même cause. En effet, malgré la vocation militaire des Ordres, il n'apparaît aucun indice de l'intervention du castellán dans les combats qui opposaient les clans. L'attitude de Pedro Ruiz de Moros semble bien avoir été de refuser obstinément toute compromission avec la violence...", escriu Bonneaud (BONNEAUD, op. cit., p. 133) La declaració de Fra Pascasio Martín, prior de Montsó, en el procés contra Roiç de Moros desmunta la suposició de Bonneaud en afirmar que el Castellà d'Amposta era i actuava com a capità general de les tropes armades del Comte d'Urgell "Et dixit se scire quod dictus Castellanus, una cum Anthonio de Luna, faciebat partem et dabat adjutorium Comiti Urgelli et vidit quod, ipso teste existente in Almunia, dictus Castellanus erat capitaneus generalis omnium gentium armorum dicti Comitis et partis sue." (ACA, Cancelleria, Processos en volum, lligall 47, Plec A, fols. 130 v.- 146 r.)

${ }^{15}$ Arxiu de Malta, Lib. bull. Mag., XXV, fol. 74 b.

${ }^{16}$ Delaville Le RoulX, op. cit., p. 342. 
primer dia de juliol de 1418 i va trametre l'afer judicial a l'examen del Gran Mestre i de l'assemblea de l'Orde. L'assemblea va ordenar obrir un nou procés i, el 31 d'agost de 1418, va obligar els diferents detentors de peces del procés a lliurar-les al procurador de Roiç de $\operatorname{Moros}^{17}$. La solució definitiva no va tenir lloc fins dos anys més tard en l'assemblea general del mes de setembre de 1420, un cop ocorreguda la mort de Gundisalvo de Funes. I justament la mort d'aquest va ser determinant en l'acabament del conflicte -cosa òbvia- pel que fa a la contenció entre els dos frares santjoanistes. Mort Funes, no trigaria ja gaire a deixar també aquest món Roiç de Moros, puix que en el mes de desembre de 1421 ja feia dos anys que era mort ${ }^{18}$.

Però el conflicte jurisdiccional que s'arrossegava entre el Papa i l'Orde de l'Hospital pel que fa al nomenament del Castellà seguia viu. En efecte, mentre que el capítol general de Rodes del 29 de setembre de 1420 nomenava vicecastellà Fra Pere de Liñán, el papa Martí V nomenava nou Castellà d'Amposta Fra Álvaro de Luna, membre de la família de Benet XIII, nomenament que només s'explica per raons tàctiques i polítiques, això és, per separar Fra Álvaro de l'obediència del papa reclòs a Peníscola. Es repetia novament la situació que es va donar quan el papa Benet XIII nomená Castellà d'Amposta Roiç de Moros i l'Orde de l'Hospital féu el nomenament de Gundisalvo de Funes. Tanmateix, en aquest cas, Martí V, atenent i acceptant les queixes de l'Orde que li va fer veure que la col-lació de les dignitats priorals no corresponia al Papa sinó al Gran Mestre, es va fer enrere del camí emprès i, el 6 de juny de 1421, a requeriment del Gran Mestre, va confirmar el nomenament de Fra Pere de Liñán ${ }^{19}$.

Pel que fa al contenciós de la Castellania d'Amposta entre Pedro Roiç de Moros i Gundisalvo de Funes, el papa Martí V, vist el procés, va emetre sentència, el text de la qual va enviar a l'Orde de l'Hospital en carta butlla adreçada al Gran Mestre i capítol general que s'havia de reunir a Avinyó:

\footnotetext{
${ }^{17}$ Arxiu de Malta, Lib. bull. Mag. XXVII, fol. $90 \mathrm{~b}$.

${ }^{18} \mathrm{ACA}$, Cancelleria, 3237, fols. 160 v.-161 r. Hi ha més precisió sobre la data de la mort a la Cancelleria Reial. En document del rei Alfons el Magnànim, signat al monestir de Sant Cugat del Vallès el 22 d'octubre de 1419, hi ha esmentada la persona "fratris Petri Roiç de Moros, qui apud civitatem eandem [Dertuse] diem suum non est diu clausit extremum". Així, doncs, consta documentalment que el Castellà d'Amposta morí a Tortosa l'any 1419. ACA, Cancelleria, reg. 2751, fol. 45 r.v.

${ }^{19}$ Delaville Le RoulX, op. cit., p. 342, nota 6. Arxiu de Malta, lib. bull. mag., XXX, fol. 91 b; div. VII, vol. 1131 (bull. 1200-1500), fol. 348.
} 
"Philiberto Magistro et Capitulo generali fratrum Hospitalis Sancti Johannis Jerosolimitani Avinione proxime celebrando...". Els urgia a posar fi al contenciós al més aviat possible i en última instància seguint els estatuts i costums de l'Orde: “... vocatis dicto Petro et Gundissalvo et aliis qui fuerint evocandi, causam huiusmodi juxta stabilimenta et consuetudines supradicta huic debito omni appellatione remota terminare seu terminari facere nullatenus postponatis, super quo vobis plenariam tenore presentium ex habundante cautela concedimus potestatem" 20 .

Entorn de la figura de Fra Pedro Roiç de Moros i de l'actitud política que va adoptar durant l'interregne successori a la Corona d'Aragó, en els primers anys del regnat de Ferran d'Antequera i en els darrers anys del Cisma d'Occident, hi descobrim diversos personatges, els uns centrals i els altres molt influents en aquells esdeveniments històrics, també institucions i col-lectius, tots ells relacionats i lligats per la força dels fets: el papa Benet XIII, amb els seus cardenals i la cort pontifícia; el nou rei sorgit de Casp, Ferran d'Antequera; el pretendent Jaume d'Urgell, "el Dissortat"; el comte Antonio de Luna; els hospitalers Fra Gundisalvo de Funes i Fra Íñigo de Alfaro; el Gran Mestre Filibert de Naillac; el Concili de Constança; Martí V, el nou papa sorgit del concili; Fra Pascasi de Morralla, prior de Sant Joan de Montsó; l'arquebisbe de Saragossa, García Fernández de Heredia; i els cardenals de Benet XIII, membres del tribunal creat per processar Roiç de Moros: Joan, del títol de Sant Llorenç "in Damascho" (sic), cardenal prevere, i Pere, del títol de Sant Àngel, cardenal diaca.

En llurs imbricacions personals trobem alhora les imbricacions factuals dels dos esdeveniments més significatius i potents d'aquell moment a la Corona d'Aragó: l'Interregne succesori i el Cisma d'Occident. Per això, entre els documents o peces inclosos dins els procés hi figura el manual dels nou compromissaris de Casp: "Manuale negotiorum factorum per novem personas que facere debent noscionem, investigationem et publicationem Regis" ${ }^{21}$. Com hi figura també, arran de l'apel-lació de Roiç de Moros al Concili de Constança, l'acta que dóna fe de la reunió del conclave i de l'elecció del papa Martí V: "Introitus conclavis. Anno et indictione quibus supra $\left(\mathrm{M}^{\circ} \mathrm{CCC}^{\circ} \mathrm{XVII}{ }^{\circ}\right.$, indictione $\left.\mathrm{X}^{\mathrm{a}}\right)$, die Lune, octava mensis Novembris,

\footnotetext{
${ }^{20} \mathrm{ACA}$, Cancelleria, Processos en volum, lligall 47. Plec 106/40, fol. $161 \mathrm{v}$.

${ }^{21} \mathrm{ACA}$, Cancelleria, Processos en volum, lligall 47. Plec 102/33. 27 folis.
} 
Reverendissimi in Christo patres et domini, miseratione divina Sacrosancte Romane Ecclesie Cardinales in Civitate Constantiensi existentes una cum deputatis quinque nationum intrarunt conclave ad Summum Pontificem eligendum..."22.

Té raó, doncs, Bonneaud quan escriu: "Ainsi les enjeux de la succession au trône d'Aragon et de l'issue du schisme pontifical apparaissaient-ils comme très étroitement imbriqués dans les prises de positions, les comportements et les arrières pensées des hauts dignitaires des Ordres Militaires de la Couronne, quels qu'ils fûssent" ${ }^{23}$.

Els efectes del procés inquisitorial obert contra Pedro Roiç de Moros queden recollits en els documents de la Cancelleria Reial d'acord amb la cronologia i els diferents moments o estadis processals. Així, en carta reial de Ferran d'Antequera, escrita el 8 d'agost al papa Benet XIII, consta que, l'any 1413, Roiç de Moros era suspès de la dignitat de Castellà d'Amposta. En la carta, el rei demanava al papa que, atès que "ut didicimus, frater Petrus Roderici de Moros, olim Castellanus Emposte, a dicta Castellania est suspensus", li designés una persona al capdavant de la Castellania a qui pogués exigir les aportacions, ja acostumades a exigir pels seus predecessors, per fer front a les càrregues i despeses de la seva coronació ${ }^{24}$.

L'any següent, 1414, figura com a regent la Castellania Fra Íñigo de Alfaro, que alhora tenia l'encàrrec del tribunal papal d'inquirir sobre la vida, costums i gestió del Castellà Roiç de Moros ${ }^{25}$. I, de dos anys més tard, trobant-se la Castellania en mans d'Íñigo de Alfaro, la Cancelleria Reial guarda dos documents datats el dia 11 de gener de 1416, quan Ferran d'Antequera ja havia negat l'obediència al papa Luna, i en ells hom revela que els castells de Miravet i de Montsó, dues importants fortaleses hospitaleres, apareixien fornides "axí d'armes, vitualles, com de gents e altres coses" per Benet XIII i els seus partidaris, forniment que només era possible comptant amb la col-laboració, o si més no amb el consentiment, de Fra Gundisalvo de Funes, partidari de Benet XIII, qui actuava aleshores com a legítim Castellà,

\footnotetext{
${ }_{22}^{2} \mathrm{ACA}$, Cancelleria, Processos en volum, lligall 47. Plec 106/40, fols. 34 r.- 35 v.

${ }^{23}$ Bonneaud, op. cit., p. 139.

${ }^{24} \mathrm{ACA}$, Cancelleria, reg. 2383, fol. $109 \mathrm{r}$.

${ }^{25} \mathrm{ACA}$, Cancelleria, reg. 2407, fol. $87 \mathrm{v}$.
} 
un cop suspès Roiç de Moros $^{26}$. Governant aquest la Castellania haurien estat impossibles, fins i tot impensables, l'avituallament, el proveïment d'armes i de gents i el decantament i ocupació dels dos castells al servei dels interessos del papa refugiat a Peníscola.

El 17 d'octubre de 1417, el rei Alfons el Magnànim escrivia un cop més al rector de Sant Mateu, Mn. Francesc Janer, després d'haver-ho fet mantes vegades, exigint-li de lliurar a Fra Gundisalvo de Funes, Castellà d'Amposta, la còpia del procés papal contra Roiç de Moros: "quatenus copiam fidem ferentem processus facti olim in Curia Romana contra fratrem Petrum Roderici de Moros, olim Castellanum Emposte, traderetis... fratri Gundisalvo de Funes, Castellano eiusdem Castellanie, vos tamen usque nunc id facere distulistis..."27.

Del mateix any és el memorial que els ambaixadors havien de presentar en nom del rei Alfons davant el nou papa de Roma, Martí V, sorgit del Concili de Constança, demanant la confirmació de la dignitat de Castellà a favor de Fra Gundisalvo de Funes: "Micer Jordi Ornos, procurador del Rei en Cort Romana, per part del Rei Alfons, supplicarà al nou Sant Pare ...Ítem farà supplicació al Sant Pare en favor del Castellà d'Amposta que sia confirmat en sa Castellania" 28 .

El 17 de març de 1418, el rei Alfons escrivia personalment al papa Martí V des de València i li feia saber, o li recordava novament, que Roiç de Moros, pels seus demèrits, havia estat privat de la Castellania d'Amposta pel papa Benet XIII legalment, previ procés solemne i públic, i amb la deguda sentència judicial, i que havia estat elevat a l'esmentada dignitat Fra Gundisalvo de Funes, persona de vida íntegra i de provada virtut: "Frater Petrus Roderici de Moros, suis exhigentibus demeritis, per tunc dominum Benedictum Papam XIII, predecessorem vestrum, seu de eius mandato instructo, inde servato iuris ordine, solemni processu a dicta Castellania

${ }^{26} \mathrm{ACA}$, Cancelleria, reg. 2408, fol. 89 r.; 90 v.-91 r. L'any 1413, temps en què es van fer els interrogatoris als testimonis del procés contra Roiç de Moros, Fra Gundisalvo de Funes era a Peníscola, a la cort del papa Benet XIII, i en la casa on habitava va ser interrogat (Lligall 47, plec A, fol. 130 v.).

${ }^{27}$ ACA, Cancelleria, reg. 2459, fol. 168 r.v.

${ }^{28} \mathrm{ACA}$, Cancelleria, reg. 2400 , fol. 65 v. 
sententialiter fuit sublatus, promoto canonice ad eandem venerabili religioso et dilecto nostro fratre Gondissalvo de Funes... viro integerrime vite..."29.

El 28 de febrer de 1420, Roiç de Moros com a Castellà d'Amposta havia desaparegut de l'escena política i el rei Alfons tenia molt clar que, de ple dret, la Castellania d'Amposta era a mans de Gundisalvo de Funes. Ho demostra la carta que li envià, de Tortosa estant, relativa a l'afer de dos homes, "lo un cristià e l'altre moro", detinguts per ordre reial a la vila de Batea per Garcia Muntanyes, domèstic de la casa del rei, a qui el batlle, el sotsbatlle i els jurats i prohoms de Batea, "allegant aquell no haver poder de pendre e haver los dits hòmens", no deixaven prendre de la vila; el monarca obligà el Castellà, "sots incorriment de nostra ira e indignació", a intervenir en el cas, "com aquells sien vagabunds e hòmens de mala vida e tals que donen e són àbils al exercici de les nostres galees..." ${ }^{30}$.

El 23 de desembre de 1421, Roiç de Moros ja era mort. Així consta per una sentència de la reina Maria de Castella, signada en aquesta data a Barcelona, en la qual condemna Joan Ros, notari, administrador dels béns del Castellà d'Amposta, Fra Pedro Roiç de Moros, difunt, a pagar dels béns relictes d'aquest 37 lliures i 10 sous a Fra Garcia de Torres, comanador d'Ascó, doctor en lleis i promotor dels negocis de la cort reial; el pagament li corresponia en concepte de salari que li era degut pel fet d'haver-li encarregat el Gran Mestre de Rodes la representació dels drets de l'Orde de l'Hospital en el contenciós entre Roiç de Moros i Gundisalvo de Funes, Castellà d'Amposta, també difunt ${ }^{31}$.

\section{MODEL O PAUTA PER A L'INTERROGATORI DELS TESTIMONIS}

Els cardenals que formaven el tribunal creat pel papa Benet XIII per a jutjar el Castellà d'Amposta Fra Pedro Roiç de Moros necessitaven la màxima i més precisa informació fidedigna sobre la seva vida, costums, observança dels deures propis de la religió de l'Hospital, tracte personal, administració i gestió pública dels béns mobles i immobles com ara castells,

\footnotetext{
${ }^{29} \mathrm{ACA}$, Cancelleria, reg. 2563, fol. $123 \mathrm{r}$.

${ }^{30} \mathrm{ACA}$, Cancelleria, reg. 2568, fol. 101 r.v.

${ }^{31} \mathrm{ACA}$, Cancelleria, reg. 3237, fols. $160 \mathrm{v} .-161 \mathrm{r}$.
} 
capelles, cases, finques i altres propietats de l'Orde existents dins la Castellania. Necessitaven així mateix informació sobre els delictes que li eren atribuïts, també sobre els fills seus, les seves concubines i les activitats dels uns i de les altres, el tracte que donava als seus vassalls, la cura que tenia de les capelles de l'Orde i del culte diví que hi calia mantenir o fomentar.

La informació havien de recollir-la els dos comissionats, Fra Íñigo de Alfaro i Fra Pascasio de Moralla, de frares de l'Orde, de vassalls de la Castellania i d'altres persones cridades a deposar. Els testimonis que van ser escoltats foren seixanta-set. De frares, varen ser-ne cridats a declarar vint, si bé tenim d'ells vint-i-una declaracions perquè Fra Salvador de Luna, preceptor de Nonasp, va declarar dues vegades; i de vassalls, quaranta-set, entre els quals hi havia trenta-un cristians i setze sarraïns.

La pauta o model d'interrogació als testimonis constava de 40 capítols, almenys aquest n'era el nombre previst, si bé en el plec que recull les declaracions dels testimonis rebuts només n'hi ha 39. El contingut dels respectius capítols és el que segueix

El capítol 1 tracta de l'estat, manteniment i dotació de personal i d'objectes de culte de les esglésies i capelles de l'Orde situades en el territori de la Castellania.

El capítol 2 tracta de l'atenció personal, moral i econòmica del Castellà d'Amposta a les necessitats vitals dels capellans seculars i frares servidors de les esglésies i capelles de l'Orde.

El capítol 3 tracta de l'obligació del Castellà de pagar als frares conventuals llur vestuari i de mantenir altres persones de l'Orde segons costum.

El capítol 4 es refereix a la informació sobre els llocs i comandes de la Castellania on era costum o llei que el Castellà donés almoina, i a la constatació d'haver-hi fet o no l'almoina.

Els capítols 5, 6 i 7 es refereixen a l'estat material dels castells, esglésies, capelles i altres edificis de l'Orde, si eren enderrocats, des de quan, i si el Castellà havia fet adobaments, quan i quins.

El capítol 8 es refereix a les rendes de la Castellania, de les seves comandes i batllies, al valor que tenien en el moment de fer-se'n càrrec el Castellà i al que tenien en el temps en què es feia l'interrogatori judicial, esbrinant-se si havien patit disminució, quanta i des de quan, i si l'administració era bona o no. 
El capítol 9 es refereix a l'administració o cura ordinària i extraordinària de les finques rústiques pertanyents a la cambra del Castellà.

Els capítols 10, 11 i 12 es refereixen al tracte degut pel Castellà als seus vassalls, i són destinats a obtenir informació de les vexacions, extorsions, processos injustos i altres maltractaments causats pel Castellà, els seus fills o els seus oficials i familiars. I a esbrinar si per causa dels maltractaments s'havia despoblat alguna vila o comanda o la mateixa Castellania.

Els capítols 13 i 14 tracten del lliurament dels castells de les comandes en poder dels fills del Castellà, dels seus familiars o d'altres persones laiques, traient-los de les mans dels frares de l'Orde, sobretot en el període de l'interregne successori de la Corona d'Aragó, esbrinant si els esmentats detentors dels castells havien fet tort, injúria o danys als servidors dels castells esmentats.

El capítol 15 es refereix als possibles establiments a cens o arrendaments fets en frau de l'Orde pel Castellà i als arrendaments concedits als seus fills i familiars.

El capítol 16 es refereix als establiments a cens i alienacions de béns que podien haver estat executats pels castellans anteriors a Roiç de Moros, i a esbrinar quina era l'actitud d'aquest, curosa o negligent, en l'afer.

El capítol 17 tracta d'esbrinar si Roiç de Moros, amb diners de l'Orde, havia pagat o ajudat a pagar el cost del castell i lloc d'Almedíxer i l'alcaidia d'Albarrasí o qualssevulla altres béns a favor del seu fill Joan Roiç de Moros o d'altres fills seus.

El capítol 18 tracta del lliurament als fills del Castellà o a persones laiques de la seva confiança dels tresors, privilegis, pergamins, butlles i altres escriptures de l'Orde, i de l'estat actual, referit a la data de les interrogacions, dels arxius i tresors de la Castellania.

El capítol 19 tracta dels furts d'armes, roba i forniments de les fortaleses hospitaleres de la Castellania, amb especial concreció al castell de Miravet, realitzats pels fills o familiars laics del Castellà amb consentiment d'aquest.

Els capítols 20,21, 22 i 23 es refereixen als deutes carregats pel Castellà Roiç de Moros als seus vassalls, quants eren, quant en pagava de pensió i per què els havia carregats, si era per a servei i utilitat de l'Orde de l'Hospital o solament a profit seu, dels seus fills, parents o amics. Si els deutes havien estat causa de danys i execucions contra els vassalls de la Castellania o d'arrendaments a baix preu de possessions de la Castellania. 
El capítol 24 tracta d'esbrinar si el Castellà havia exigit o rebut de les municipalitats de l'Orde de l'Hospital quantitats de diners en efectiu amb l'ocasió de pagar els deutes contrets i si aquests diners havien estat posats al servei de l'Orde o a benefici particular del Castellà i dels seus fills i familiars, deixant en descobert les municipalitats extorquides.

Els capítols 25 i 26 es refereixen a la vida moral de Roiç de Moros, si havia tingut o tenia encara concubina o concubines, quantes, quines i en quins llocs de la Castellania, si això era públic i notori entre els frares, vassalls $i$ altres persones, si tenia ja concubina quan va ser elevat a la dignitat de Castellà d'Amposta i si d'elles o d'alguna d'elles havia tingut algun fill, quants n'havia tingut, qui eren, i si aquests el reconeixien públicament com a pare i ell els reconeixia així mateix com a fills.

Els capítols 27 i 28 es refereixen a l'ajuda que el Castellà havia donat a Antonio de Luna contra el governador d'Aragó, Roiç de Lihori, i els Urrea durant l'interregne, i van destinats a esbrinar si ell mateix, els seus fills o altres persones del seu entorn s'havien armat per combatre militarment, i si per causa o amb ocasió d'això havien patit danys els vassalls, els edificis, castells i heretats de l'Orde de l'Hospital per part dels adversaris del comte de Luna.

Els capítols 29, 30 i 31 tracten dels possibles abusos comesos pel Castellà d'Amposta en atorgar comandes o priorats $\mathrm{i}$ altres beneficis de l'Orde, pronunciar sentències o sentenciar contra justícia, a canvi de quantitats dineràries, caient així en simonia i en prevaricació.

El capítol 32 té com a finalitat esbrinar si en castells o altres edificis de l'Orde situats dins la Castellania d'Amposta Roiç de Moros havia consentit o consentia, o almenys n'havia tingut notícia o ho sabia, de tenir-hi allotjats i mantinguts alguns apòstates, heretges o persones supersticioses.

El capítol 33 tracta de l'obligació dels visitadors d'informar-se sobre el títol amb què Roiç de Moros posseïa la Castellania d'Amposta.

El capítol 34 tracta de l'obligació d'informar-se els visitadors de la Castellania de les quantitats que havien pagat i havien de pagar les cambres del Castellà en concepte de responsió o pagament periòdic pagador al tresor de l'Orde.

El capítol 35 es refereix a la vida religiosa i de pietat del Castellà Roiç de Moros, si confessava els seus pecats i combregava en les festes solemnes i senyalades de l'any, si resava les hores litúrgiques de l'ofici diví i si tenia 
costum de guardar i fer observar fidelment les cerimònies pròpies de l'Orde de Sant Joan.

El capítol 36 torna a insistir en la manera de fer justícia el Castellà als seus vassalls, si havia estat negligent o els havia cobrat i fet extorsió a canvi de la justícia exigida i deguda.

El capítol 37 va destinat a esbrinar si el Castellà té fet inventari dels béns immobles i mobles de la Castellania, si guarda bé i té posat al dia el llibre d'inventari i els llibres corresponents dels drets i censos de les seves comandes o batllies.

El capítol 38 tracta de la presència de concubines en les comandes de la Castellania, si hi havia religiosos que en tenien, públicament o secreta, i si el Castellà en tenia notícia.

El capítol 39 és un intent explícit d'aconseguir que res no escapi al coneixement del tribunal i demana als testimonis que diguin si saben que el Castellà hagi comès algunes altres coses o excessos redundants en dany de la Castellania i de l'Orde o en deshonor de la religió de l'Hospital de Sant Joan de Jerusalem.

"Et los sobreditos quaranta capítolos son del tenor siguient

1. Primerament, si las Eglesias e capiellas de las comandas o cambras del dito Castellán, de su tiempo, son stadas e son de present mantenidas de capellanes e ministros segunt el buen uso e costumbre. Et ornadas de vestiments, panyos, cálices, libros, lumbrarias e otras cosas pertenescientes al dito culto divino.

2. Ítem si el dito Castellán, de todo su tiempo, ha bien o mal satisfecho a los priores, clérigos, capellanes o ministros de las ditas Eglesias o capiellas.

3. Ítem si el dito Castellán ha bien pagado e ha acostumbrado de pagar los vistuarios a los frayres conventuales, los quales ha havido sustener, e a otras qualesquiere personas de la dita orden que haya havido a sustener.

4. Ítem que se informen por testimonios o en toda otra manera que puedan en quales lugares de las comandas del dito Castellán es acostumbrado en tiempo passado o se deve fazer almosna e si en aquellos lugares si es fecha por el dito Castellán de todo su tiempo o de qué tiempo es fallida.

5. Ítem si en las comandas o cambras del dito Castellán de Amposta son algunos Castiellos, casas, Eglesias o edifficios derrocados en todo o en part, e de qual condición son los ditos derrocamientos.

6. Ítem si los ditos derrocamientos son fechos de tiempo del dito Castellán o si eran ya antes de su tiempo.

7. Ítem si el dito Castellán ha fecho algunos adobos o reparaciones en los ditos Castiellos, casas o edifficios e quales.

8. Ítem quanto valían las rendas de cada una de sus baylías, comandas o cambras en el tiempo que él començó de seyer Castellán et quanto valen agora de present et si las ditas 
rendas son diminuydas que es la razón de aquesta administración. Et infórmense strechament los ditos visitadores quanto vale agora una de las ditas comandas si fuesse bien regida o bien administrada.

9. Îtem si el dito Castellán tiene e ha acostumbrado tener de todo su tiempo en buen condrecho las vinyas, tierras, olivares e qualesquiere otras heredades que sean a mano de sus comandas o cambras.

10. Ítem si el dito Castellán ha acostumbrado a maltractar los vassallos e súbditos de sus comandas faziéndoles vexaciones, injustos processos o justas extorsiones e otros malos tractamientos.

11. Ítem si permete o consiente o ha permetido o consentido que los ditos vassallos sian maltractados e vexados por los fillos de el mismo Castellán o por sus officiales, procuradores o familias e quales son aquellos maltractamientos.

12. Ítem si por el maltractar que fazen o han fecho los ditos Castellán, fillos, officiales o familias suyas de los ditos vassallos se sigue disipación de los ditos vassallos o que algunos dellos sen sian ydos a poblar o habitar a otras partes fuera la senyoría del Spital.

13. Ítem sil dito Castellán ha puesto en mano e poder de sus fillos o de otras personas legas los castiellos e fortalezas de sus comandas, mayorment en el tiempo que vagava el Regno de Aragón.

14. Ítem si los ditos fillos del Castellán e otras personas tenientes los ditos Castiellos han fecho algunos males o danyos a ningunas personas o guerras de los ditos Castiellos.

15. Ítem si el dito Castellán ha asensado o arrendado en frau de la orden o ha non devidament alienado algunas heredades pertenescientes a la orden en sus fillos, parientes 0 familiares, o en otras qualesquiere personas.

16. Ítem si por los predecessores del dito Castellán en las ditas sus baylías o cambras son stados fechos o fechas algunos assensamientos, algunas alienaciones non devidament en la revocación o recobro de las quales sia stado negligent el dito Castellán.

17. Ítem sil dito Castellán con bienes e peccunias de la orden ha pagado o ayudado pagar el Castiello e lugar d'Almedíxer pora su fillo Mossén Johan Royz de Moros e l'alcaydiado d'Albarrazín o otros qualesquiere heredades o bienes poral dito Johan Royz o a otros sus fillos.

18. Ítem sil dito Castellán ha lexado o ha acostumbrado lexar en mano o poder de sus fillos o de otras legas personas los trasoros, privillegios, cartas e auténticas scripturas de la orden. E se ha visto e reconoscido bien como stan los ditos trasoros, privillegios e scripturas.

19. Ítem si los Castiellos e fortalezas de la orden, mayorment el Castiello de Miravet, son stados privados e despullados de muchas armas e de muchas robas e de muchos fornimientos e bienes por sus fillos del Castellán o por otros legos sabiendo aquesto et consentient el dito Castellán.

20. Ítem sil dito Castellán en tiempo passado ha cargado e acostumbrado cargar deudos e quales eran los deudos, e de quantas sumas e quanto ende pagava de logro o de pensión e por quales razones o occasiones cargava los ditos deudos, si los cargava por cosas que fuessen utilidat o provecho de su Religión o que fuessen por negocios proprios suyos o de sus fillos o de sus parientes o otras personas.

21. Ítem quantos e quales son los deudos que deve de present e quanta es la sort principal de cascuno e quanto paga por cascuno de logro o de pensión. 
22. Ítem sil dito Castellán por sus deudos o negocios ha fecho o acostumbrado fazer obligar los vassallos de la orden e que por aquesta occasión los ditos vassallos hayan havido e sostenido execuciones e danyos e sostengan hoy en día e quantos son los deudos de present del dito Castellán por los quales sian hoy de present obligados vassallos de la orden.

23. Ítem sil dito Castellán por occasión de sus deudos ha fecho e acostumbrado fazer arrendamientos de las rendas de sus baylías o cambras por mucho menor precio que no se acostumbrava de arrendar o que no valían. Et aquesto por tal com li avançavan de donar antes de tiempo el precio del arrendamiento o gran part de aquel e quales son stados aquestos arrendamientos e quales personas e a qué tiempo et por qué precio.

24. Ítem sil dito Castellán por color e occasión de quitar de deudos algunas universidades del Spital ha recebido de aquellas algunas quantias de dineros, los quales seha spendido en otros usos proprios non queriendo quitar las ditas universidades.

25. Ítem sil dito Castellán en tiempo antes que fuesse Castellán e aprés que es Castellán ha tovido concubina o concubinas públicament $o$ ascondida e por quanto tiempo ha tovido cascuna de aquellas e cómo havían nombre e si es fama de aquesto, e reputado por público e notorio entre los comendadores e freyres e vassallos del Spital e entre otras personas. Et si tenía concubina quando fue fecho Castellán.

26. Ítem sil dito Castellán de las ditas concubina o concubinas ha havido fillos e fillas, e qui son aquellos e aquellas et si son havidos e reputados por tales públicament e notoria. Et si los unos e los otros entre si se reputan por padre e fillos e fillas públicament et notoria et quales fillos ha havido de cascuna concubina nomenadament.

27. Ítem sil dito Castellán ha fecho part o ayuda a Don Anthon de Luna o se sea armado o fecho armar sus fillos e otras companyas con el dito Don Anthon en la guerra e bandosidades capitales que el dito Don Anthon ha tenido e menado contra Mossén Gil Royz de Lihori quando era governador de Aragón, Don Pedro de Urrea e otras muchas personas.

28. Ítem si por razón o occasión de la dita part o ayuda lorden del Spital es stado muy dampnificado en casas, edificios, heredades, possessiones e bienes por los adversarios del dito Don Anthon e del dito Castellán.

29. Ítem sil dito Castellán por donar comandas o priorados o otros beneficios de la orden ha tomado dineros o otras cosas temporales o haya obtenido absolución de algunos deudos o obligaciones.

30. Ítem sil dito Castellán por donar algunas sentencias o por color de ministrar justicia entre los vassallos del Spital ha por pacto o en otra manera recebido pecunias faziendo las sentencias o justicia venales e si de aquesto es fama.

31. Ítem si sabe, creye o ha oydo dezir que por pronunciar sentencia en favor de la una de las partes haya tomado part de la peccunia contenida en la condempnación partiendo aquella con la part, precedent pacto o conllusión o en otra mala manera. 
32. Ítem si en los Castiellos o casas de las cambras o comandas del dito Castellán son stados o son de present sostenidos algunos apóstatas ${ }^{32}$ e si aquesto ha sopido o sabe de present el dito Castellán.

33. Ítem se deven informar los visitadores con qué títol possedex la Castellanía.

34. Ítem se deve informar quanto deven pagar o ha acostumbrado pagar de responsión cada una de las cambras del Castellán en tiempo pasado.

35. Ítem si en las fiestas anyales e solempnes el dito Castellán ha confessado o recebido el Sagrament de la Eucaristía e cómo dize e ha acostumbrado dezir sus oras ${ }^{33}$ o oraciones e si ha acostumbrado servar et guardar las cerimonias de su Religión et si las ha acostumbrado ferlas servar a los otros religiosos de la su orden.

36. Ítem sil dito Castellán es stado o acostumbrado de star negligent en fazer e ministrar justicia entre sus vassallos e si por ministrar los la dita justicia los ha fecho algunas demandas o extorsiones.

37. Ítem sil dito Castellán tiene inventario o libro de los bienes, censos e dreytos de sus baylías o cambras.

${ }^{32} \mathrm{Amb}$ el nom d'apòstata no s'identifica aquí cap persona que hagi abandonat la fe cristiana sinó aquella que, pertanyent a un orde religiós, ha canviat a un altre orde irregularment, això és, contra les lleis canòniques i sense llicència del seu superior. En el cas del procés que ens ocupa apareixen com a apòstates els frares sanjoanistes que han entrat a l'orde procedents d'altres ordes religiosos com ara agustins, dominics o franciscans, per exemple, $i$ ho han fet amb consentiment o coneixement del Castellà, malgrat la irregularitat canònica del canvi d'orde.

${ }^{33} \mathrm{Amb}$ el terme "Horas, Oras" se significa l’Ofici Diví, això és, les Hores Canòniques, que els monjos, frares, religiosos i sacerdots havien de resar en diferents moments del dia segons la distribució horària dels romans: Ad matutinum amb 3 nocturns, Ad laudes, Ad primam, Ad tertiam, Ad sextam, Ad nonam, Ad vesperas, Ad completorium. Els frares santjoanistes no sacerdots, com Fra Pedro Roiç de Moros, resaven un ofici reduït que és el que contenen els anomenats Hores o llibres d'Hores, obres medievals il-lustrades, algunes d'elles vertaderes obres d'art. La seva estructura interna era aquesta

1. Calendari, amb els dotze mesos de l'any, les quatre estacions i els signes del Zodíac; les festes del Senyor i de la Mare de Déu i el santoral de cada dia; els anys; el nombre d'or; i les lletres dominicals.

2. Textos dels quatre evangelis, els corresponents a les festes del Senyor més importants: Nadal, Epifania, Encarnació (Anunciació de la Verge Maria), Pasqua de Resurrecció, Ascensió i Pasqua de Pentecosta. S'hi podien afegir el pròleg de l'evangeli de Sant Joan, els textos relatius a les aparicions de Jesucrist als apòstols després de la Resurrecció i una de les dues genealogies de Jesucrist, la de Sant Mateu o la de Sant Lluc. propis.

3. L'Ofici de la Mare de Déu, complet, amb els salms, antífones, himnes i oracions

4. L'Ofici de la Creu, complet.

5. Els Set Salms Penitencials (salms 6, 31, 37, 50, 101, 129 i 142).

6. Pregàries a sants de devoció especial a l'edat mitjana, depenent també de la regió geogràfica, de la diòcesi, de l'orde religiós o de la devoció personal de l'usuari del Llibre d'Hores: Sant Cristòfol, Santa Caterina, Sant Sebastià, Santa Àgata, Santa Úrsula i les 11.000 verges, Sant Jeroni, Sant Joan Baptista, Sant Miquel, Sant Gregori, Sant Bernat, Sant Pere, Sant Pau, Sant Andreu, Santa Llúcia, Sant Joan Evangelista, Sant Antoni Abat i Santa Bàrbara. Aquests sants són els que figuren amb major freqüència.

7. L'Ofici de Difunts, només amb tres hores litúrgiques: vespres, matines i laudes. 
38. Ítem si dentro las baylías o comandas del dito Castellán en tiempo passado o de present son sostenidos algunos religiosos de la dita orden tenientes concubinas públicament 0 ascondida e que aquesto haya supido e sostenido el dito Castellán.

39. Ítem sil dito Castellán, ultra las cosas de susso ditas, ha fecho o cometido algunas otras cosas e excessos vinientes en danyo e perjudicio de la orden o deviantes de la honestat de su Religión" ${ }^{34}$.

\section{LA RECEPCIÓ DE TESTIMONIS DECLARANTS}

Els comissionats per rebre la declaració dels testimonis van poder escoltar les persones cridades a declarar en un termini de temps que va començar el dia 9 de febrer de 1413 i es va tancar el 27 d'octubre del mateix any. Els comissionats, si bé van començar a rebre testimonis al castell de Miravet, considerant més àgil i pràctic per al compliment de la tasca encomanada desplaçar-se a les ciutats, viles i llocs de residència dels testimonis per rebre llurs declaracions, varen visitar-les seguint un ordre metòdic. Les declaracions quedaven sempre recollides en escrit per un escrivà que en certificava l'autenticitat. Totes elles s'han guardat en el plec que he denominat Plec A del lligall 47.

Les anomenades "deposiciones de testimonios" eren escoltades "por nosotros, fray Énnego de Alfaro, Comendador de Ricla et de Enzinacorba... et fray Paschual de Moralla, prior de la Eglesia de Sant Johan de Monçon, de la diócesis de Lérida, de la orden del Spital de Sant Johan de Jerusalem, comissarios e visitadores por el muyt Santo Padre et Senyor nuestro senyor el Papa Benedicto XIII, deputados en las cambras e comandas de don fray Pero Roiz de Moros, Castellán de Amposta, e de don fray Gonçalvo de Funes, comendador de Cantaviella et de Aliaga".

$\mathrm{Hi}$ assistia com a conseller, "Assesor siquiere consellero micer Miguel de Lobera, doctor en Decretos et Rector de Maella" i, com a escrivà o notari, "et en notario Mossen Francisco Giner, notario de la Cambra apostolical".

${ }^{34} \mathrm{ACA}$, Cancelleria, Processos en volum, lligall 47, plec A, fols. 2 r.- 5 v. 
"Los quales testimonios començamos a recebir en el Castiello e villa de Miravet... el VIIII ${ }^{\circ}$ dia de febrero, Anno a Nativitate Domini Millesimo CCCC XIII" 35 .

L'ordre de les deposicions testificals, amb informació de les dates, llocs de domicili i identitats dels testimonis, és com segueix

a) Castell de Miravet, 9 de febrer de 1413

1. Deposició de "Fray Dalmau Dezcoll, cavallero del orden de Sant Johan del Spital, L anyos ha, el qual recibió l'ábito del dito orden el dia mesmo quel recebió el dito Fray Pero Roiz de Moros, agora Castellán de Amposta, en la Capiella de Sant Miguel sitiada en el dito Castiello de Miravet. Et el qual Fray Dalmau es hombre de LXV anyos o cerqua et ha regido el Castiello de Miravet con su baylía con tiempos e partidas de XXX anyos" (Plec A, fols. 7 v.-21 r.)

2. Deposició de "Fray Miquel Calvo, prior qui huey es de la capella del Castiello de Miravet, de XXX anyos o cerqua, frayre de dito orden cerqua ha XIIII anyos" (fols. 21 r.-24 r.).

3. Deposició de "Fray Johan Emperador, frayre sargant del dito orden, rebostero del Castiello de Miravet, de edat LV anyos, frayre ha cerqua de XVIII anyos" (fols. 24 r.-26 v.).

4. Deposició de "Fray Miguel de Mirallas, frayre sargant del Castiello de Miravet cerqua ha de XVI anyos, de edat XXX." (fol. 27 r.)

5. Deposició de "Mahoma Xeverti, moro alamí de la villa e aljama de Miravet", de 30 anys, "ha IX anyos o cerqua que regexe por el dito senyor Castellán el officio del alamí en la dita aljama, testimonio jurado et por su sagrament que es ville alladi leylea yllan unacip dech algueble"(f. 27 r. -28 v.).

6. Deposició d' "Axer Bernadella, moro de la aljama e villa de Miravet", de 58 anys (fols. 28 v.-30 r.).

7. Deposició d' "Homat Abolafez, moro de l'aljama e villa de Miravet", qui declara sobre l'aljama (fols. 30 r.-31 r.).

8. Deposició de "Lop lo Ferrero, moro de l'aljama e villa de Miravet", qui declara sobre l'aljama (fol. 31 r.-v.).

\footnotetext{
${ }^{35}$ ACA, Cancelleria, Processos en volum, lligall 47, plec A, fol. 1 r.v.
} 
9. Deposició de "Ferrig Çalmedina, moro de la aljama e villa de Miravet", de 50 anys (fols. 31 v.-32 v.).

10. Deposició d' "Abdelluz Maureso, moro de la aljama e villa de Miravet”, de 40 anys (fols. 32 v.-33 r.).

11. Deposició d' "Alí Fierro, moro de la aljama e villa de Miravet", de 60 anys (fol. 33 r.-v.).

b) Benissanet, 17 de febrer de 1413

12. Deposició de "Brahem Alguz, moro de Beniçane, de LX anyos, qui nasció en Miravet, e ha habitado en esta de Beniçanet de XL anyos ençá" (fols. 33 v. -35 r.).

13. Deposició de "Mahoma Algordell, moro de Beniçane", de 60 anys (fols. 35 r. -38 v.).

14. Deposició d' "Homat Alfrez, moro de Beniçane", de 60 anys (fols. 38 v. -41 v.).

15. Deposició de "Zaheyt Alberdil, moro de Beniçane", de 65 anys (fols. 41 v. -42 v.).

16. Deposició d' "Alí Castanyoles, moro de Beniçane", de 35 anys (fols. 42 v. -43 v.).

17. Deposició d'Azmet Abdereli, moro de Beniçane", de 60 anys (fols. 43 v. -44 r.).

c) Ginestar, 22 de febrer de 1413

18. Deposició de Pero Segura, veí de Ginestar, de 65 anys (f. 44 r-v) 44 v. -45 r.).

19. Deposició de Domingo Polvell, veí de Ginestar, de 50 anys (fols.

d) Rasquera, 23 de febrer de 1413

20. Deposició de Pere Aulea, veí de Rasquera, de 40 anys (fols. 45 v. -47 r.)

21. Deposició de Guiamó Poll, veí de Rasquera, de 50 anys (fols. 47 r. -48 v.). 
e) Pinell, 1 de març de 1413 48 v. -50 v.)

22. Deposició de Guillem Canalda, veí del Pinell, de 60 anys (fols.

23. Deposició de Llorenç Pascuet, veí del Pinell, de 65 anys (f. 51 v.)

f) Gandesa, 4 de març de 1413

24. Deposició de "Blasius de Lihori, vicinus Dertusensis, habitator Gandesie", de 70 anys (fols. 51 v. -57 v.)

25. Deposició de Ramon Jover, "que nasció en Corbera e ha habitado e sta en Gandesa de XXX anyos ençá”, de 55 anys (fols. 57 v.-60 r.)

26. Deposició de "Bernardus Vitalis", de 40 anys, veí de Gandesa (fols. 60 r.- 62 v.)

g) Corbera, 9 de març de 1413

27. Deposició de Llorenç Aguiló, de 60 anys, veí de Corbera (fols. 62 v. -64 r.)

28. Deposició de Domingo Nanguera, de 60 anys, veí de Corbera (fols. 64 v. -66 r.)

29. Deposició de Bernat Miquel, de 50 anys, veí de Corbera (fols. 66 r. -67 v.)

h) Ascó, 14 de març de 1413

30. Deposició de "Fray Anthonio Sánchez, cavallero de San Juan, qui era e es regidor del Castiello de Azcón e ha cerqua de XX anyos que recibió el hábito" (fols. 67 v.-73 v.).

31. Deposició de Pere Figuera, de 55 anys, veí d'ascó (f. 73 v- 75v.).

32. Deposició de Çalema Caxeres, moro, veí d'Ascó, de 55 anys (fols 75 v. -77 r.).

33. Deposició de "Fray Miguel de Penya, cavallero de San Juan, de XL anyos, e ha cerqua de XX que ha recibido el hábito" (fols. 77 v.-81 v.).

34. Deposició de Montoliu Izmail, moro, veí d'Ascó, de 40 anys (fols. 81 v. -83 v.). 
35. Deposició de Fomat Abihafia, moro, veí d'Ascó, de 50 anys (fols. 83 v. -85 r.).

36. Deposició de "Franciscus Aguiló", veí d'Ascó, de 50 anys (fols. 85 r. -88 v.).

i) Vilalba, 27 de març de 1413

37. Deposició de Duran Albert, veí de la Fatarella, de 50 anys (fols 88 v. -90 v.).

38. Deposició de Bernat Criviller, veí de Vilalba, de 50 anys (fols. 90 v. -91 v.).

39. Deposició de Maties Guasch, veí de Vilalba, de 60 anys (fols. 91 v. -92 r.).

j) Batea, 30 de març de 1413 r.-v.).

40. Deposició de Guillem Folquer, veí de Batea, de 30 anys (fol. 92 v. -93 v.). v. -94 v.).

41. Deposició de Bernat Vilomar, veí de Batea, de 50 anys (fols. 92

42. Deposició de Guillem Guimerà, veí de Batea, de 40 anys (fols. 93

k) Casp, 3 d'abril de 1413 95 r.-v.)

43. Deposició d' "Eximinus de Casp", veí de Casp, de 24 anys (fol.

1) Chiprana, 4 d'abril de 1413

44. Deposició de Domingo Nabals, veí de Chiprana, de 55 anys (fols. 95 v. -96 v.).

45. Deposició de Domingo Pallás, veí de Chiprana, de 60 anys (fol. 96 v.).

46. Deposició de Ferrer Don Sancho, veí de Chiprana, de 70 anys (fols. 96 v. -97 r.). 
m) Saragossa, 7 d'abril de 1413

47. Deposició de "Fray Salvador de Luna, Comendador de Nonasp, de edat XLV anyos o cerqua, e ha XXXIII anyos o cerqua que recibió el hábito" (fols. 97 r.-106 v.).

48. Deposició de "Fray Johan Calbet, Prior de las Casas de San Joan de Çaragoça, de edat L anyos o cerqua, e ha XII anyos o cerqua que recibió el hábito" (fols. 106 v.-107 v.).

49. Deposició de "Fray Pero Rosellón, Procurador en los letigios de las Casas de Çaragoça, de edat LV anyos o cerqua, e ha XVIII anyos que recibió el hábito" (fol. 108 r.-v.).

50. Deposició de "Fray Andreu Martínez de Agodesa, Prior de Santa María del Temple de Çaragoça, de edat LX anyos o cerqua, e ha XXXV anyos que recibió el hábito" (fols. 108 v.-110 v.).

n) La Almunia de Dona Godina, 22 d'abril de 1413

51. Deposició de "Petrus Sánchez de Villacroch", veí de l'Almúnia, de 45 anys (fols. 110 v. -112 v.).

52. Deposició de "Johan Sthevan, presbítero, beneficiado en la Eglesia de la Almunia", de 55 anys (fols. 112 v.-115 r.).

o) Lloc de Grisenich, comanda de Saragossa, 26 d'abril de 1413

53. Deposició de "Fernando de Villar de Salas", veí de Grisenich, de 40 anys (fol. 115 r.-v.).

p) Mallén, 28 d'abril de 1413

54. Deposició de "Johan de Çalmedina", veí de Mallén, de 50 anys (fols. 115 v.-116 v.).

55. Deposició d' "Anthon de Japues, notario", veí de Mallén, de 40 anys (fol. 117 r.-v.).

56. Deposició de "Fray Ximeno Daranço, regidor de la Comanda de Mallén, de edat XL anyos o cerqua, e ha XVIII anyos que recibió el hábito" (fol. 118 r.-v.). 
57. Deposició de "Fray Gonçalvo de Lihori, Comendador de Anyón e de Noviellas, de edat L anyos o cerqua" (fols. 118 v.-119 v.).

58. Deposició de "Fray Martín de Lodosa, Prior curado de la Eglesia Parroquial de Mallén, de edat XL anyos o cerqua, e ha XVIII anyos que recibió el hábito" (fols. 120 r.-121 r.).

q) Sant Mateu, 25 de juliol de $1413^{36}$. "Apud villam Sancti Mathei, diocesis dertusensis, Michael de Lobera, Decretorum doctor, rector ville de Maella, recepit medio juramento ab infra nominandis depositiones sequentes" (fol. $121 \mathrm{r}$ ).

59. Deposició de "Frater Berengarius de Casanova, preceptor de Térmens" (fol. 121 r.-v.).

60. Deposició de "Frater Salvator de Luna, preceptor de Nonasp" (fols. 121 v. -122 v.).

q) Peníscola, 26 de setembre de 1413. "Peniscole, in domo habitationis Domini Fratris Gundisalvi de Funes, prioris Cathalonie..." (fol. 122 v.).

61. Deposició de "Frater Gundisalvus de Funes" (fol. 122 v.-130 v.).

62. Deposició de "Frater Paschasius Martini, prior Sancti Johannis Montissoni". 28 de setembre de 1413 (fols. 130 v.-146.).

63. Deposició de "Frater Ennecus de Alfaro, comendator de Ricla et de Enzinacorba". 5 d'octubre de 1413 (fols. 146 r.-150 v.).

64. Deposició de "Frater Michael de Penya, professor ordinis et vicarius de Ontinyent", de 55 anys d'edat. 20 d'octubre de 1413 (fols. 150 v. -152 r.).

65. Deposició de "Dominus Johannes Siurana, Prior Ecclesie Dertusensis". 29 de setembre de 1413 (fol. 152 r.).

66. Deposició de "Frater Jaufridus Canadal, comendator de Ulldecona". 30 de setembre de 1413 (fols. 152 r. 157 v.).

67. Deposició de "Frater Salvator de Luna, comendator de Nonasp et de Alcolea". 27 d'octubre de 1413. És aquesta una nova declaració del frare santjoanista en aquest procés. La seva declaració va acomapanyada

\footnotetext{
${ }^{36}$ En el document figura l'any 1414 , però entenc que és un error de l'escrivà o del copista. L'any 1414 eren ja recollides les declaracions testimonials i el procés seguia el seu curs.
} 
d'aquesta nota obligant-lo sota jurament al més rigorós secret: "Injunctum fuit sibi silentium per juramentum". 27 d'octubre de 1413 (fols. 157 v.-162 r.).

68. Deposició de "Frater Arnaldus Armengol, quondam de Valentia". 27 d'octubre de 1413 (fols. 163 r.-173 r.).

\section{El MEMORIAL DE VISITA DE LA CASTELlaNiA}

El tribunal de cardenals format pel papa Benet XIII per a inquirir, jutjar i sentenciar Fra Pedro Roiç de Moros "de vita et moribus, de religionis observantia... ac de regimine et administratione in Castellania et preceptoriis" no en tenia prou amb la recepció dels nombrosos testimonis; els cardenals necessitaven conèixer, de manera objectiva i directa, l'estat real de la Castellania d'Amposta, i això no era possible sense fer les visitacions que creguessin convenients i necessàries a les diferents preceptories o comandes de la Castellania.

Les visitacions eren un recurs ordinari de l'Orde de Sant Joan de Jerusalem i servien per assegurar el bon funcionament de les cases i comunitats de l'Hospital, vigilar la convivència dels seus membres, vetllar per la conservació i bona administració dels béns mobles i immobles, i, com a recurs extraordinari, per resoldre amb urgència $i$ eficàcia algun problema sorgit entre els frares o entre aquests i els seus vassalls.

La visitació ordenada pel tribunal papal arran del procés tingué caràcter extraordinari i tenia la finalitat de proporcionar als membres del tribunal aquell coneixement real de les coses i situacions que només una inspecció ocular dels llocs i objectes i un contacte viu i directe amb les situacions i persones poden proporcionar. A més, els resultats obtinguts de la visitació permetien contrastar la realitat coneguda, examinada, amb les declaracions testificals; d'aquesta manera, les informacions eren més completes i objectives i la veritat podia quedar, així, més garantida.

El procés inclou entre les seves peces un memorial pràctic "de avisamientos" adreçat als visitadors per tal que no arribessin als llocs de visita dejuns d'informació. Hom veu que el memorial segueix l'ordre dels capítols d'interrogació als testimonis i, pel que fa a una part dels capítols, dóna als visitadors informació significativa de situacions, estat de les coses i fets relatius a la Castellania d'Amposta, incloent-hi persones -frares i vassalls-, propietats rústiques, edificis militars, civils i religiosos, com ara castells, 
esglésies i cases, i béns mobles. I recull les informacions que havien arribat a oïda dels membres del tribunal abans de començar-se el procés. El memorial ocupa els folis 5 v.- 7 v. del Plec A.

"Et de los ditos avisamientos el tenor es atal.

Aquesto es memorial a los visitadores del Castellán sobre algunas cosas particulares que son venidas en noticia, las quales se ponen aquí por mayor avisamiento de los visitadores e que ellos meior ne sepan la verdat.

[1] Sobre la materia del primer capítol dízese que quant se ha de dezir missa al Castiello de Miravet han haver cáliz e patena del Castiello de Azcón o pel contrario, tengan buena manera los visitadores que no los puedan enganyar mudando los arreamientos de las unas Eglesias o capiellas en las otras.

[2] Sobre la materia del $\mathrm{II}^{\mathrm{0}}$ capítol dízese quel dito Castellán no paga bien al prior de l'Almunia su pensión ni paga lo que deve pagar a los capellanes de la casa que tiene lorden en Saragossa. Ítem más se dize que grant tiempo ha que una questión que era entrél Comendador de Casp... e el prior de Xiprana sobre la primicia del dito lugar fue firmado compromés en el dito Castellán, el qual no ha pronunciado en la dita questión más de $\mathrm{X}$ anyos ençá..

[3] Sobre la materia del III capítol se dize quel dito Castellán acostumbró de mal pagar los vistuarios a sus conventuales.

[4] Sobre la materia del IIII capítol se dize que en el tiempo que durava el debato de la successión del Regno no se fizo almosna en las casas de Çaragoça.

[5] Sobre la materia del $V^{0}$ capítol se dize quel Castiello de las Cuevas, de la Comanda de Castellot, se derroquó de todo quando el dito Castellán era comendador de Castellot. Ítem quel templo de Çaragoça ha menester grant reparación que noyde bastarían dos mill florines. Ítem que las casas de Çaragoça han menester grant reparación. Ítem que en la comanda de Çaragoça ha un molin destructo que solia valer $\mathrm{CCC}^{\text {s }}$ florines. Ítem que en las tierras del Castellán sus enemigos han dado muchos dampnages. Ítem quel Castiello de Miravet e d'Azcon han menester grant reparación. Ítem que en el lugar de Corbera ha una grant casa do solían star vaxiellos de vino que es toda destructa.

[6] Sobre la materia del VIIII capítol dízese que las vinyas d'Azcon son destroydas.

[7] Sobre la materia del $X^{\circ}$ capítol et de los dos capítols siguientes se dize que muchos vassallos, e mayorment sarraynos, del dito Castellán, mayorment de Miravet, de Azcon, de Gandesa et de Batea sen son ydos fuera la senyoria del orden por el mal tractar del Castellán e de sus fillos e de sus officiales o procuradores.

Ítem quel dito Castellán con injusticia tomó e havió de un sarrayn calderero đAzcon $\mathrm{D}^{\text {os }}$ florins. Ítem que sentenció a muert un sarrayn đ’Azcon por los bienes que valían más de $\mathrm{X}$ mil florins. Et fizo donación de los bienes a su fijo Pero Roiz, sepan todo aquesto. Ítem que fizo morir en preson el hermano del dito sarrayn e tomó li los bienes. Ítem sobrel fecho dels damunt ditos sarraynes sean avisados los visitadores que hayan los processos fechos por el Castellán e hayan los del scrivano mismo de los processos. Ítem que del lugar dAlpartil e del lugar de Fuent de Xalon se son ydos todos los vassallos. Ítem quel dito Castellán fizo obligar a un hombre suyo a qui dizen Carcases a unos judíos de Falcet, la qual obligación li fizo fer con una letra de creyença e depués ha dito el dito Castellán que no era aquella la creyença, e assín es romaso en el mal e fazen le la execución. 
[8] Sobre la materia del XIII capítol e del otro siguient se dize quel dito Castellán ha acostumbrado de comanar a sus fillos e a hun alsogre de su fillo Gil Royz los castiellos de Miravet e d'Azcon.

[9] Sobre la materia del $\mathrm{XV}^{\circ}$ capítol dízese que el dito Castellán dio a censo una foya en el término de Miravet por la qual havie $\mathrm{CCCC}^{\circ}$ florins de entrada, la qual foya solia seyer a rella del orden. Ítem que tomó los bienes de Fray Bartholomeu Prats que solia tener el Castiello de Gandesa, qui senforquó e fizonde donación a un su servidor a censo de X sols. Ítem que asignó a Gil Royz su fillo las rendas de Benissanet, de la baylía de Miravet. Ítem que ha asignado a Fray Guillem Joli el lugar de Berruz e el lugar de Ribaroya, qui son de la comanda d'Azcon.

[10] Sobre la materia del XIX ${ }^{\circ}$ capítol se dize que en la capiella e convento de Miravet, antes que aquesti fuesse Castellán, solia haver tres cáliçes đargent e IIII ${ }^{\circ}$ taças d'argent et en el convento de Çaragoça tres taças d'argent et todo es perdido de tiempo desti Castellán.

[11] Sobre la materia del XXIP capítol se dize en special de una obligación en $\mathrm{X}^{\mathrm{M}}$ sols. en que fizo entrar los hombres de la Almunia quando compró Almedíxer para su fillo Mossén Johan Royz.

Ítem quel dito Castellán por fuerça fizo obligar los hombres de Gandesa cerrando las puertas de la villa e non de lexava sallir ninguno porque non querían fazer la obligación por él

[12] Sobre la materia del XXIIIP capítol se dize quel Castellán fizo pacto con la villa de Corbera que le diessen cierta cosa e él sacar los hia de deudos, e aprés que huvo tomado dellos cierta quantía háselo spendido. Et por semblant ha fecho al lugar de Torrent de Cinqua.

[13] Sobre la materia del XXVIP capítol se dize que su fillo yva con don Anthon de Luna con la gent o companya de su padre el Castellán.

[14] Sobre la materia del XXIX capítol se dize quel dito Castellán, quando donó l'abadia de Ballobar a fray Miguel Bonfill, tomó d'él $\mathrm{CCC}^{\text {os }}$ florins. Ítem, quando donó l'abadia d'Alcolea al dito fray Miguel Bonfill, tomó d'él $\mathrm{DCCC}^{\circ}$ o Mil florins. Ítem que por el priorado de Mallén tomó IIII ${ }^{\mathrm{M}}$ sols. Ítem que, quando donó la comanda de Cinqua a Pero Royz su fillo, tomó las rendas de tres anyos.

[15] Sobre la materia del $X X X^{0}$ capítol se dize que una questión era entre el comendador d'Ulldecona e la universidat de Ulldecona sobre penas que les demandava e fue puesta la questión en poder del Castellán e él condempnó la dita universidat en quatro mil florines e partieron los se él e el Comendador car yan de havían fecho pacto malvado amos a dos; de aquesto se sabe la verdat en Ulldecona ab en Jachme Linya, notario.

[16] Sobre la materia del $\mathrm{XXXP}$ capítol se dize que una questión era entre la universidat de Ulldecona de la una part e lo logar de la Cénia de part otra devant el Castellán et por tal que donasse sentencia por part d'Ulldecona tomó mucha quantía de dineros e también sen de tomó de la otra part por tal que por ellos pronunciás de todo aquesto, pora saber la verdat en Ulldecona, demanden an Jachme Linya, notario, qui lo scribe, e les dirá de otros quey saben. 
[17] Sobre la materia del XXXVI capítol se dize que fray Roger d'Urries, comendador d'Ambel, tomó por fuerça una fadrina et que la madre ne fizo clamo al Castellán en la Almunia et noyde fizo ninguna justicia ne corrección" ${ }^{37}$.

\section{LES DECLARACIONS DELS TESTIMONIS}

Les declaracions dels testimonis escoltats pels comissionats del tribunal format per Benet XIII donen molta llum sobre la persona, la vida i l'obra de govern del Castellà d'Amposta Fra Pedro Roiç de Moros. És clar, però, que hem de prendre amb reserva el valor de les testificacions, almenys el d'algunes, tant més quant que en la iniciació del procés i en el decurs del mateix hi hagué voluntat d'acabar amb la vida política i el prestigi personal de Roiç de Moros, i el procés tenia com un dels seus motors, segons que sembla, la venjança; alguns testimonis podien haver declarat -o callat- sota coacció moral o, almenys, condicionats per les situacions en què es trobaven, o potser influenciats per interessos que afectaven llurs persones, llurs famílies o llurs vides. Crec que abonen la reserva sobre les declaracions testificals els silencis i confessions d'ignorància sobre certs temes per part d'alguns testimonis, així com les dades probablement exagerades que uns altres aporten.

L'objectivitat i la veritat que voldríem trobar en les peces testificals del procés crec que caldrà buscar-les en el punt d'intersecció de les declaracions dels testimonis i de les dades recollides en els documents de visita de les diferents comandes, viles i llocs de la Castellania. La coincidència de les dades de visita amb les declaracions testificals es pot entendre lògicament com una garantia de veritat. Per això, acompanyaré les declaracions testificals amb les dades recollides pels visitadors.

Nota. Les declaracions dels diferents testimonis queden recollides per capítols seguint l'ordre dels capítols proposats com a pauta per a les interrogacions testificals.

Les declaracions han estat seleccionades, com ho han estat també els testimonis declarants, en funció de l'interès i quantitat d'informació que aportaren davant el tribunal sobre la persona, vida, costums, governació i estat de la Castellania i implicació del Castellà Roiç de Moros en la situació política de l'interregne successori a la Corona d'Aragó.

${ }^{37} \mathrm{ACA}$, Cancelleria, Processos en volum, lligall 47, plec A, fols. 5 v.-7 v. 
La identitat de cada declarant figura amb nom i cognom, professió o càrrec i veïnatge en aquell capítol on apareix per primer cop la seva declaració.

Cada declarant té assignat un nombre, el mateix que acompanya la identitat nominal en la llista dels testimonis del procés de l'apartat 4. Aquest nombre, que precedeix el nom dels declarants, és un nombre constant, el mateix que correspon a cada testimoni per lordre en què apareix en el Plec A del lligall del procés. I és el nombre que identifica cadascun dels declarants en les declaracions que es recullen dins de cada capítol.

La referència documental de les respectives declaracions testificals apareix en el cos de l'article darrere la identitat nominal de cada testimoni en l'apartat 4 i també al final de les declaracions respectives, aquí en nota a peu de pàgina, dins el present apartat 6 .

\section{Capítols 1 i 2 . Del manteniment de preveres $i$ dotació d'esglésies $i$} capelles en les viles $i$ llocs de la Castellania.

1. Fra Dalmau Dezcoll, cavaller de l'Orde de l'Hospital, declara que "En la capiella del dito Castiello de Miravet ha tiempo visto que solían star dos o tres presbíteros, uno qui es el prior e otros, quandoque frayres, quandoque seculares, e asin la visto acostumbrar en tiempo desti Castellán e antes en tiempos de Fray Ferrándiz de Heredia e de Fray Martín de Lihori, lahora castellanes. Et que no sabe que por institución o en otra manera deven esser más presbíteros.

El dito prior e el otro presbítero no havían renda perpetua e certa sino quel prior recebie del Castellán su vestiario, que son LX sols. e la taula a él e a su scolá et más sus pertanços de las parroquias del Ginestar et de Rasquera, de que es curado. Et quel otro presbítero, si era frayre, havía semblant vestiario quel prior; si era secular, su soldada segunt con él se podían convenir.

... Creya que a los priores e presbíteros que en las otras capiellas han servido en el tiempo desti Castellán les sian pagados sus vestiarios e soldadas, e sábelo por tanto porque non da oydo clamar a ninguno sino al capellán Folquer de Gandesa, el qual servió en las ditas capiellas en tiempo quel alcayt d'Azcón procurava las rendas del dito Castiello (...) le parece que al capellán Folquer le era devido entorn de V o VI florines car assin ge lo havia oydo dezir.

En las ditas capiellas, del tiempo desti Castellán ha havido quatro priores con el que oy regexe, ço es fray Elías, fray Guillem de Alfajarín, fray Matheu Scudero et Fray Miguel Calvo qui huy es prior. Et seculares, muytos, los nombres de los quales non le recuerdan sino de IIII' ${ }^{\circ}$, ço es el dito En Folquer, e un Muntanyes, En Thomás e En Jachme de Bas qui huy es sierve. Et que esto sabía por tanto quanto a los ditos priores e capellanes seculares ha visto en el sobredito tiempo cantar et celebrar en las ditas capiellas (...) Los ditos priores e capellanes no han tenidas mancebas en tiempo que servían las ditas capiellas en tiempo del dito Castellán (...) Han fecho bien el servicio divinal.

Ninguno de los sobreditos priores o capellanes fueron apóstatas, homicidas o irregulares, sino de uno desusso dito quis clamava fray Matheu Scuder, el qual se dizia que era stado de la orden de los augustinos. Empero quando vino al dito Castiello de Miravet vino sin hábito alguno e aprés esti Castellán diole el hábito de Sant Johan. E esto sabe porque el dito testimonio era en el Castiello quando el dito fray Matheu vino sines hábito... Creye que depués que se fue vestido, el Castellàn supo que Fray Matheu fuesse frayre de otro orden... El 
Castellán no havia expellido el dito Fray Matheu del dito Castiello, pues esto se dizia. Mas el dito Fray Matheu cerqua un mes ha passado que se fue no saben do.

Interrogado si las ditas capiellas eran bien ornadas de vestimentos, cálices, panyos, libros, luminarias e otras cosas pertenescientes al culto devino. Dixo que se referia al Inventario por nosotros, ditos visitadores, feyto. Et a la visión quen de havíamos feyta corporalment car por aquellos podríamos veyer cómo stavan ornadas las ditas capiellas.

En aquella hora - quando esti Castellán tomó posesión de la dita Castellanía e del Castiello de Miravet- hi vió ell testimonio quey havia tres cálices con sus patenas đargent, la uno daurado con senyal de Fray Sánchez d’Aragón, lahora Castellán, e los otros dos blanquos, las copas dauradas dentro. Et que podían ser de peso todos tres de VI marques o cerqua. En aquel mismo tiempo, en la sacristía de la dita capiella havia una cruzeta petita d'argent en la qual havia dos troços de Ligno Domini en cruz. Et estos cálices e cruzeta hoy noy son. La cruzeta tomó el senyor Castellán et la levava en sus coffres. Et dixo que de los cálices los dos son stados robados entre dos vegadas, de los quales el uno trobaron sin patena sclafado dentro la dita capiella dius las cadiras scondido. Et que assin sclafado posieron lo en la sacristía, d'allí avant no es parecido et non sabe el testimonio ques fizo. Et quel tercero cáliz, que era el que tenía senyal del dito Fr. Sancho, de mandamiento del dito Castellán, Fr. Sancho de Urbanya, capellán suyo, agora abbat de Ballobar, londe levó a Çaragoça por servicio del dito Castellán... El testimonio estava en el Castiello de Miravet quando las ditas cosas fueron fechas. Los ditos dos cálices havían robados, es cierto, las companyas que eran en servicio del dito Castellán. Et de esto es cierto o lo creye, quel Castiello es bien cerrado e guardado que noy de habitavan sino los quel dito Castellán tenía o mandava. El último cáliz ha cerqua de dos anyos. Et que luego que aquel fue robado, hovieron el que huey tienen de la capiella del Castiello d'Azcón.

Interrogado si sabe quel dito Castellán, quando los ditos cálices fueron perdidos, fiziesse su diligencia en cobrarlos o saber quién lo havia fecho. Et dixo que sabe quey fiziesse otra diligencia sino que le supo muyto greu. Et esto sabe porquey dera present.

En la capiella de Santa María dels Castiello de Miravet ende cremavan quatro lámpadas, et en la de Sant Miquel no ninguna porque la capiella era enderrocada, es verdat quey de solian antes cremar dos lámpadas. Et dixo que en la capiella de Santa Maria, de dos anyos entaqua, non di han cremado sino tres lámpadas. Et ha fallecido una, la que se clama de los scuderos, que no ha cremado. Et dixo que en la capiella de Sant Miquel, de dos anyos entaqua endia cremado una diziendo que la sobredita de los scuderos fue mudada a la dita capiella de Sant Miguel.

No sabe que haya rendas ciertas assignadas por las ditas lámpadas sino la ques clama de los scuderos ques dize que aquella e una candela ques clama de los ditos scuderos que deve siempre nueyt e dia cremar en la dita capiella con la dita lámpada, han certas rendas en Batea e Rasquera. No sabe quantas rendas fueron asignadas por las ditas candela e lámpada e no sabe más que las ditas rendas, basten o no basten, el Castellán es tenido tener las ditas candela e lámpada ensemps con las otras lámpadas en condreyto que cremen delant lo Corpus Christi de nueyt e de dia. Et dixo que aquesto sabía porque lo ha visto e praticado por los castellanes. Siempre han cremado assin, o almenos si han fallido algunas oras es stada culpa de los priores e scolares et no del dito Castellán, car cera e olio prestos eran por darlos. 
No sabe si en el dito tiempo el dito Castellán ha augmentado vestimentes o ornamentos algunos a las ditas capiellas, es verdat quendi procuró uno que era stado de fray Johan Fernández, maestro del Spital.

2. Fray Miguel Calvo, prior de la Capiella del Castiello de Miravet. ... Del tiempo entaqua que él sta en el dito Castiello de Miravet, que son tres anyos e medio o cerqua e vino la hora del convento de Casp, puede dezir et sabe que quando vino trobó en el dito Castiello quatro o cinquo capellanes. Et de tres meses entaqua que sen fue Fr. Matheu Scuder, la hora prior de la dita capiella, son stados siempre tres presbíteros e algunas oras quatro. Et depués quel dito Fr. Matheu sen fue, siempre hide son stados dos e alguna vegada tres. Et de present hi son tres, ço es, el testimonio, Fr. Phelip Salamó, frayre del dito orden, e Jacme de Bas, presbítero secular. Et dixo quel servicio divinal, quanto él entendia e havia visto, que devidament lo fazian. Et que en el dito tiempo nondi conosció ninguno, priores, frayres e presbíteros, que él supiés que tinguesse manceba. Et que de la fama e condicion de los sobreditos non podia dir en quanto conoscia sino bien. Es verdat empero que del dito Fr. Matheo, la hora prior, era fama entre los del dito Castiello que era estado de otro orden, ço es, de los agustinos o predicadores. Et que era nigromàntich, e esto sabia por oyda, que lo havia oydo dezir a muytos, de los nombres de los quales non se acordava. Interrogado si sabia quel dito Fr. Matheu, apóstata, celebrasse el oficio divinal estando en el dito castiello e las Eglesias curadas de Rasquera e del Genestar annexas al dito priorado. Et dixo que sí, e esto sabe porque assin lo vidíe.

Interrogado si sabia quel dito senyor Castellán hoyés la missa del dito Fr. Matheu apóstata. Et dixo que no, ans havia oydo dezir a sus cambreros que non queria oyr missa del dito fray Matheu. Interrogado si sabia por qué el dito Castellán no queria oyr missa del dito Fr. Matheu. Et dixo que creya porque era nigromàntich. Et dixo que él, testimonio, no sabia res quel dito Castellán supiesse quel dito Fr. Matheu fuesse apóstata e nigromàntic.

Interrogado si sabia que de las ditas capiellas de Santa Maria e de Sant Miguel del dito Castiello fuessen o sean stados furtados o presos tres cálices d'argent e una cruzeta con Ligno Domini. Et dixo que bien sabe que un cálice fue furtado estando él, testimonio, enfermo en Gandesa. Et esto sabia porque assin lo havia hoydo dezir a los del dito Castiello; de la cruzeta et los otros cálices, dixo que noy de sabia res. E que no sabia por culpa de quién era stado furtado. Et dixo que bien vido que li supo muyt malo al dito senyor Castellán, hovida noticia del robamiento del dito cáliz, et que dixo an Godenchcs, su procurador, quey dasse diligencia, que él se hiva enta nostre senyor el Papa a Alcaniz.

En la capiella de Santa Maria han cremado de dia et de nueyt continuament tres lámpadas e una candela de cera. En la capiella de Sant Miguel siempre ha visto cremar una lámpada. Et agora, de poco tiempo entaqua, endi creman dos. de Miravet.

3. Fray Johan Emperador, frayre sargant del orden del Spital, rebostero del castiello

Et dixo que en su tiempo son stados en las capiellas del castiello de Miravet Fr. Johan Elias, Fr. Guillem d'Alfajarin, Fr. Pedro d'Epila, Fr. Matheu Scudero e Fr. Miguel Calvo, qui hoy es, priores del dito castiello e capellanes otros, de los nombres de los quales no se acuerda. Et mas dixo que en quanto él, qui es lego, puede entender, que son stados hombres buenos e de buena conversación et fazian bien su oficio. Excepto quel dito fray Matheu, segunt se dizie, que era apóstata e que era nigromántico. Et dixo quel dito Castellán fizo frayre de Sant Johan al dito Fr. Matheu. Et dixo quel dito senyor Castellán, quando li dio l'ábito, no sabia quel dito 
fr. Matheu fuesse de otro orden, mas quel testimonio hoyó dezir quel dito Castellán, aprés, supiendo esto, reptó muyto al dito Fr. Matheu porque lo havia enganyado e se baralló con él. Et dixo que de joyas que fallen de las ditas capiellas del Castiello de Miravet del tiempo desti Castellán no sabe sino de tres cálices e una cruz de fulla d'argent e una cruzeta en la qual havia de ligno Domini, ques dize que fallen. Et esto no sabe si son en la dita capiella o a do son, que esto deven saber el prior e los capellanes.

Interrogado si sabia quantas lámpadas solian cremar en la dita capiella de Santa Maria, et dixo que tres davant l'altar de Santa Maria e al otro cabo de la dita capiella stavan los Retaulos de Sant Miguel e Sant Jordi porque la capiella de Sant Miguel era enderrocada, e delant aquellos retaulos cremava otra lámpada. Et quando la dita capiella de Sant Miguel fue tornada, levaron los ditos retaulos con la propdita lámpada a la capiella de Sant Miguel.

24. Blasius de Lihori, vicinus dertusensis, habitator Gandesie. Dixo que li acuerda que en el Castiello de Miravet vio que en tiempos passados, antes que viniesse esti senyor Castellán, hi solian star tres clérigos missacantanos, de los quales era uno el prior et los otros eran frayres o secglares, porque siempre era menester que quando el prior yva fuera por la cura de los lugares del Genestar e de Rasquera, fincassen dos en el castiello, e de tiempo desti Castellán dixo que no sabe quantos endi ha tenidos; es verdat queyda conoscidos a uno quel dezian Fr. Matheu, prior, e un presbitero seclar clamado Jacme de Bas. Et dixo quel dito Fr. Matheu era diffamado que invocava los diablos et tenia concubina públicament et notoria en el Genestar o Rasquera sabiéndolo el dito senyor Castellán. Et quel dito Fr. Matheu, temiendo la present visitación por sus peccados, es foydo no sabe a do. Et dixo quel dito Jacme de Bas es de vida diffamada, e es público e notorio en Batea que se jazia con una mujer casada en Batea e por aquello es él fora de Batea et se está en el dito castiello hoy.

Et dixo que vio que en tiempos passados, antes que esti fuesse Castellán, las capiellas de Miravet eran muyto bien ornadas de cálices, libros e vestimentos e otros ornamentos. Empero singularment no li acuerda sino quey vido tres cálices. De tiempo desti Castellán dixo que noyde sabe res. Que en los ditos tiempos que li parece queyde cremavan continuament $\mathrm{V}$ o VI lámpadas et una candela de cera. Et dixo que havia hoydo dezir a muytos en el dito Castiello que la candela era lexada por scuderos singlo con cierta renda. Et mas dixo que en la Eglesia de Sant Vicent, la qual era Eglesia parroquial de los lugares de Rasquera e del Genestar, continuament el dito orden tnia una lámpada cremant, et la Eglesia estava buena et bien cubierta e cerrada (...) El testimonio era de parentela de Don Fr. Martin de Lihori quondam Castellán.

Et dixo que ha visto que en la capiella del castiello de Gandesa un clérigo y cantava segunt era conduyto por el dito Castellán car no sabe que fuesse perpetuo. Et vio queyde cremava una lámpada e hide havia un cáliz d'argent e su vestiment e un missal.

30. Fr. Antonio Sánchez, cernant, cavallero de Sant Joan, regidor del castiello d'Azcon. Dixo que depués que el testimonio regeix el dito Castiello, que ordinariament non dia hovido ninguno capellán o frayre missacantant, sino de dos meses entaqua quendi ha uno secular, el qual no es firmado sino que send'irá quando se querá. De dos cálices queyde havia en la capiella del dito Castiello d'Azcon ha visto que la uno, por mandamiento del dito senyor, fue portado a la capiella del Castiello de Miravet porque allí nondi havia ninguno. Nunqua hi vio en la capiella de Azcon más de las ditas dos lámpadas que hoyde creman. Et sabe que de su tiempo siempre son stadas bien alumbradas, del otro tiempo passado noy sabe otra cosa sino 
que piensa que en el tiempo quel alcayde d'Azcon regia el dito castiello devian esser mal alumbradas como fuesse infiel.

33. Fray Miguel de la Penya, cavallero de San Juan. Dixo que sabe que en la capiella del castiello d'Azcon, estando él regidor del dito castiello, noyde vio ningun presbítero qui sirviesse la dita capiella como se solia servir en el tiempo antiguo. Acuerda que en las capiellas de Ribaroja et de Berruz no ha visto ni sabe quel dito senyor hi haya tenidos priores ni otros capellanes, antes stavan sin ellos.

47. Fra Salvador de Luna, comanador de Nonasp. Dixo que en las capiellas de la comanda de Çaragoça e del castiello de Miravet ha visto quel dito senyor se ha hovido, segunt el veer del testimonio, bien en ferlas servir de tres anyos entaqua que han ydo bandosidades $\mathrm{e}$ rumores en el Regno. Es ver que acuerda a él, testimonio, que en la eglesia de Berruz et de Ribaroja que de VI o VII anyos entaqua noy ha visto prior ne servirla jatsia el Castellán ni deva tener, e en la capiella de Azcon dixo que a temporadas endi ha visto capellán e non di ha visto en la capiella del castiello de Gandesa, en la qual ha oydo dezir que deve celebrar un presbítero ciertos dias cada semana segunt su intencion, la qual se deve trobar en el trasoro de Miravet.

Dixo que no sabe quel dito senyor Castellán haya comprados en las ditas capiellas de su tiempo joyas algunas ni ornamentos, mas son se mantenidas con los ornamenos que ya di de eran, de los quales creye que se han perdidos buena partida jatsia no haya noticia quales ni quantos son perdidos et esto creye que es stado en culpa porque el dito senyor Castellán no visitava las ditas capiellas e administradores de aquellas.

48. Fra Joan Calvet, "prior de la capiella de las casas de Sant Joan de Çaragoça". Dixo que en tiempo que Fr. Pere Nabal regia las ditas casas por el dito senyor Castellán fueron empenyorados dos panyos d'oro, el uno vermello e otro verde, en poder de Johan de Mayora por ciertos dineros, hoyó dezir que por XXX florins. Et nunqua son stados quitados ni sabe por qué fueron manllevados.

E mas dixo que ha oydo dezir a F. Andreu, prior del temple de Çaragoça, el qual solia antes esser prior de la dita capiella, que ciertos cálices con sus patenas fueron empenyados en poder de Beltran Coscon (...) Et dixo que no sabe que res hi haya comprado jamés sino un salterio que costó IIII $^{\circ}$ florins. Et Fr. Pere Nabal, regidor de ditas casas, huvo del testament de Dona Felicia, qui jaze en la dita capiella, cierta pecunia por a comprar un calze d'argent a la dita capiella. Et que Fr. Gil de Sada, del dito orden, qui jaze en la dita capiella, mandó de sus joyas comprar un calze de precio de XX florins per obs de la dita capiella, las joyas del qual tiene dona Maria, madre de Fr. Gil. Et estos cálices ni dineros la dita capiella nunqua ha hovidos ${ }^{38}$

62. Frater Paschasius Martini, prior Sancti Johannis Montissoni. Dixit quod in castro Miraveti vidit tempore alterius Castellani et etiam aliqua parte temporis Castellani moderni fiebat in capella dicti castri continue, sumissa voce, officium misse, et diebus dominicis et festivis, alta voce, completorium vero semper alta voce usque a duobus annis citra vel circiter quibus est secuta diminutio maxima in ministris, qui solebant esse communiter III vel IIII $^{\text {or }}$ presbiteri, et nunch non sunt nisi unus vel duo sive etiam in celebratione missarum et completorii.

\footnotetext{
${ }^{38} \mathrm{ACA}$, Cancelleria, Processos en volum, lligall 47, plec A, fols. 106 v.- 107 v.
} 
Item quoad vestimenta et pannos dicit quod vidit dictam capellam bene ornatam eisdem pannis et vestimentis quibus nunch est, nulla diminutione facta nisi eorum inveteratione, tamen dictus Castellanus modernus procuravit recuperare et recuperavit a priore de Chiprana, apud quem, ut servitorem Magistri Rodi defuncti, erat, quoddam pulcrum vestimentum aureum ipsius magistri pro capella predicta in qua nunch est.

Item quoad calices et cruces ac jocalia alia auri et argenti dixit quod vidit ibi tres calices argenteos cum suis patenis et unam parvam crucem cum duabus peciis de ligno Domini, que omnia deficiunt ibi, et audivit dici ab illis de dicto castro quod erant calices predicti furati, sed ignorat per quem et an Castellanus modernus fecit diligentiam in recuperando. De dicta cruce dixit se audivisse a Dalmacio Dezcoll, socio Castellani, quod ipse Castellanus receperat et tenebat eam in suis cofris.

Item quoad libros dixit quod vidit alias eosdem libros qui nunch sunt, sed deficiunt ibi tres, de quibus nunch recordatur, videlicet I Breviarium magnum pro capella et I Kalendarium ac liber seu Memoriale fratrum defunctorum vocatus Òbit. De aliis vero libris existentibus ibi sunt aliqui per se deteriorati propter inveterationem, alii propter culpam seu negligentiam ministrantium eos quia aliqui eorum sunt rupti per canes, ut dicebatur, alii propter malam ligaturam, alii, et plurimos, propter deffectum coopertariorum et credit quod de hiis et aliis supradictis habebat notitiam dictus Castellanus qui sepe residebat in dicto Castro et intrabat capellam et officium audiebat.

In ecclesia parochiali Sancti Vicentii extra dictum castrum, que est parochialis locorum de Rasquera e de Ginestar, distantium ab ea per mediam leucam, vidit tempore Fratris Martini de Lihori, castellani predecessoris immediati istius, quod fiebat ibi officium per priorem castri Miraveti diebus dominicis et festivis, ad quam veniebant parrochiani predictorum locorum, post vero, de licentia propria, quam bullatam vidit, fuerunt in predictis locis facte capelle antequam iste castellanus impetraret castellaniam et ab illo tempore citra cessavit fieri officium in dicta parochiali ecclesia, que erat decenter ornata libris, vestimentis et calice argenti, que hodie ibi non sunt et ignorat quid de eis factum est. Recordatur autem de quodam missali completo et officiario cum cantu que ibi vidit et non de aliis libris et ornamentis ac eorum valore.

In castro Gandesie est quedam capella, in qua, tempore immediati predecessoris Castellani moderni, vidit unum presbiterum ter in septimana ibidem celebrare de mandato ipsius Castellani, an ex debito ad hoc Castellanus teneretur vel faciebat voluntarie dictus Castellanus ignorat ipse testis, audivit tamen dici a dicto predecessore e a Fratre Dalmacio et pluribus aliis... quod ordo ad hec tenetur quia cum hac conditione fuit datus ordini per quandam Dominam locus de Nonasp ${ }^{39}$ Circa ornamenta vero dicte capelle et ad alia scripta in huiusmodi articulo vidit quod.. stant sicut solebat, salva inveteratione, et nichil scit ibi deficere.

In Ecclesiis autem parochialis Ribaroja et de Berruz consuevit esse semper I prior curatus religiosus ordinis Sancti Johannis, quem debet tenere ibi et ei et vite necessariis

\footnotetext{
${ }^{39}$ Aquesta condició fa referència a la que hauria posat a l 'Orde del Temple Elvira de Cervelló, senyora de Nonasp -la "quandam Dominam" de la declaració-, en donar al Temple de Miravet i a Guillem de Cardona, Mestre d'Aragó i Catalunya, el castell i vila de Gandesa l'any 1247 (ACA, Cancelleria, reg. 310, fol. 67 r.v. Josep A LANYÀ I RoIG, El terme municipal Carta de poblament de la Vall Major, a "La Vila Closa", I, pp. 151-159. Josep AlanYÀ I RoIG, Batea $i$ el seu terme municipal. El repoblament templer (s. XII-XIII), I, pp. 87-101.
} 
providere decenter Castellanus. Et dictus testis vidit prioribus temporibus ibi plures priores successive continuos, ab hocto tamen annis citra neminem priorem curatum ibi vidit continuum nisi aliquos seculares conducticios pro aliquibus partibus anni, sicut in $\mathrm{XL}^{40}$ et adventu et similibus, et credit quod omnia ista non ignorat Castellanus cum ipse teneatur de redditibus comandam iuxta modum anticum et consuetum ac morem ordinis providere.

In Ecclesia Sancti Johannis Cesarauguste dixit quod tempore quo frater Martinus de Liori erat Castellanus Amposte vidit ibi unum priorem ordinis Sancti Johannis et IIII ${ }^{\text {or }}$ vel $\mathrm{V}^{\mathrm{e}}$ presbiteros seculares, qui saltem missam et vesperas ac completorium celebrabant alta voce, vidit etiam tempore Castellani moderni eundem numerum personarum, que saltem usque ad tempus vacationis Regni fecerunt idem officium et etiam primam et alias horas diurnas bene et solempniter alta voce, sed a tempore vacationis Regni citra gubernator Aragonum posuit in eisdem domibus gentes castellanas ${ }^{41}$ et recepit ipse gubernator et alii de sui mandato domos et redditus ad manus suas. Ex tunch recesserunt dicti presbiteri, solo priore ibidem remanente, et cessavit celebratio alta officiorum divinorum. Quoad vestimenta dixit quod vidit istam ecclesiam pulcri ornatam... pannos autem aureos vidit ibi multos et pulcros, et est ratio nam vidit quod, mortuo Johanne Ferdinandi de Heredia quondam, domino de Mora, ipsius contemplatione fuerunt dati tres panni auri, videlicet, per ipsius uxorem, per Archiepiscopum et per Gubernatorem; mortuo autem dompno Johanne Ferdinandi de Heredia, Magistro Hospitalis, in ipsius aniversariis dati fuerunt unus per Archiepiscopum et alius panni per Civitatem sed per Anthonium de Cardona quondam, jurisperitum, vidit quod alius fuit datus. Et sepe dantur quia ibi plures notabiles persone sepeliuntur. De dictis pannis dicit se non vidisse ibi pro nunch nisi duos, et prout audivit ibidem a Fratre Andrea, priore Templi, et a Fratre Petro Rosellon, procuratore domus, tres ex dictis pannis, tempore moderni Castellani, fuerunt impignorati in posse Johannis de Majora, layci, per Fratrem Anthonium de Abella.

Quoad calices dixit se vidisse tempore Fratris Martini ${ }^{42}$, quo ipse testis erat ibi conventualis, ibidem XII calices, tam sanos quam fractos... nunch autem vidit quod nullus est, unoque quodam calice manulevato celebratur ibi. Quid autem factum est de ipsis calicibus dixit se audivisse a dicto Fratre Andrea quod, tempore coronationis Regis Martini quondam per Fratrem Petrum Nabal, regentem dictam domum nomine Castellani moderni, fuerunt impignorati decem calices fracti et sani cum eorum patenis in posse Bertrandi Coscon, mercatoris.

Capítol 3. Del pagament de vestits $i$ hàbits als frares $i$ servidors de l'Orde a la Castellania.

1. Fra Dalmau Dezcoll. El testimonio havia oydo de muytos que sende querellavan por la paga de los vistuarios, mas si son pagados o no, que no lo sabe. Dixo que ha oydo

\footnotetext{
${ }^{40} \mathrm{El}$ numeral romà s'ha de llegir "Quadragesima", això és, en temps de quaresma.

${ }^{41}$ La declaració fa palesa la nova situació a Aragó després del compromís de Casp. Des del moment que Ferran d'Antequera és rei, la presència de castellans és cada cop més gran i significativa arreu del territori de la confederació catalanoaragonesa, especialment a Aragó.

${ }^{42}$ Fra Martí de Lihori, Castellà d 'Amposta.
} 
querellar a Fr. Miguel Calvo, antes que fuesse prior, a Fr. Johan Emperador, rebostero del dito Castiello, a Fr. Domingo d'Alfore, a Fr. Miguel de Miralles, conventuales del dito Castiello, e a Johan, el donado del Genestar, e han Ripol por soldadas d'él e de su fillo, legos del Genestar, e a Ramon Vich del Genestar e a otros hombres de loguer, los nombres de los quales non le recordan.

\section{Capítol 4. De l'almoina de pa $i$ vi.}

1. Fra Dalmau Dezcoll. En el Castiello de Miravet, porque es lugar de moros, noy ha almosna ordinaria alguna, mas si freyres o duenyos o otros mendicantes vienen allí a demandar almosna, quen les dan X o XII panes e vino segunt son et que en tiempo desti se fa también como en otros tiempos passados. Et en los otros castiellos ne casas de las baylías de Miravet e de Azcón no sabe que almosna nenguna se deva fer. Cierta es verdat que sabe que en Çaragoça sen deve dar segunt ha oydo dezir a muytos.

\section{Capítols 5 i 6. De l'estat dels edificis de la Castellania i de llurs reparacions.}

1. Fra Dalmau Dezcoll. Et dixo que en el Castiello de Miravet, en tiempo desti Castellán, se ha derrocado un troz de muro en la porquería, et la cubierta de la Torre de la Verdat es cayda. Et la part de los graneros, en una partida, ses enderrocada, e partida está por caher. Et cierto panyo de antepeytos e merletes que son sobre la puerta ferrenya, los quales son cientment derrocados por opinión de repararlos. Et mas, los corredores o andadores de fusta de los muros que son des del postigo baxo de la porquería entro a la capiella de Sant Miguel son derruydos de tiempo desti Castellán. Et assin mismo los corredores que son devés Ablora delant la cambra del Castellán. Et assin mismo las xamineas de las cozinas e de las cambras, las quales cosas fazen a reparar.

En los otros lugares e casas e molinos de la dita baylía de Miavet, en tiempo desti Castellán, non se han feytos ningunos enderrocamientos, que assin se están como los trobó. Es verdat que la casa de Corbera, en do solían recullir las rendas ya antes que esti fuesse Castellán, grant tiempo havia yazia en tierra. Et que de los cubos quey de havia, ya fray Francesch Xatmar, regent la Castellania por el Maestre, ende fizo levar segunt dizian a Sant Per de Calanda uno, l'otro no sabe el testimonio ques fizo. Et mas dixo el testimonio que esti Castellán por recullir las ditas rendas de Corbera ha comprado en el dito lugar unas bellas casas con cellero, cubos e cubas. E mas dixo que un molinar de piedra, que es en Ebro deiusso el dito Castiello de Miravet, que nunquam lo vio moler ni havia oydo dezir que del tiempo del Temple entacá moliesse.

30. Fray Antonio Sánchez. Sabe que en el Castiello de Azcon no se ha res deribado o enderrocado en tiempo d'esti Castellán que no sia bien reparado et más avant construydo. Es ver que los fornos de Vinebre e de la Torre del Spanyol en las casas son derrocados. Empero ya es feyto el bestreyt de adobar los en breu. Sabe que los graneros del castiello de Miravet han menester reparación e algunas otras cosas. El Castiello de Azcon, dixo que más bien obrado 
et reparado es hoy que no era quando el senyor Castellán entró, e hoy sta bien en quanto él entiende ${ }^{43}$.

47. Fray Salvador de Luna. Et dixo que sabe que non di ha oy en Ribaroja un molino farinero de barqua en Ebro, mas ha oydo dezir a Fr. Guillem Joli, qui hoy tiene a su mano el castiello de Ribaroja, que él tornaria el dito molino si li ayudassen.

62. Fray Pascasio Martín. Dixit quod in Castro de Miravet vidit destrucciones sequentes tempore istius Castellani factas. Primo, deambulatoria que sunt ante salam Castellani. Item quod sunt castados et dirruydos los sostres de los terrados per que veniebat aqua ad aljubum; etiam sunt alique camere dirrupte. Item, merleti qui estant supra portam ferream, etiam est dirruptus seu concassatus ibi quidam paries lapideus juxta coquinam. Etiam quedam turris magna que est concassata prope portam ferream. Item est discooperta Turris appellata Veritatis. Item sunt dirrupta deambulatoria fustea a porta principali usque columbarium. Etiam sunt dirrupti parietes horreorum, etiam alius paries in parte vocata la porqueria.

Ad reparationem autem dictarum dirruptionum, dempta turri que est prope portam ferream, credit quod essent necessarii $\mathrm{M}$ floreni vel circiter; pro reparatione vero dicte Turris, que est antiqua et in tempore aliorum Castellanorum erat incepta dirrui, credit esse necessarios II mille floreni.

Dixit quod in Castro de Miravet ibi vidit unum deambulatorium coopertum de novo per dictum Castellanum, qui etiam fecit cooperire duo stabula et unam palicam ac turrim Regine et unum columbarium, et edificavit noviter capellam Sancti Michaelis, que erat totaliter destructa, et fecit portale primum dicti castri novum et unam partem muri fere X vel XII braças, credit autem huiusmodi opera decostasse $\mathrm{II}^{\mathrm{C}}$ florenos parum plus vel minus.

In comanda de Azcon, primo, in Castro fecit idem Castellanus quandam scalam lapideam pro ascensu ad quandam turrim et cooperuit eandem turrim de tribus cooperturis, in quarum qualibet fecit duos arquos lapideos; quandam aliam turrim etiam cooperuit de duabus cooperturis. In platea forana extra portam castri fecit murum lapideum longitudinis de VI vel VIII $^{\circ}$ braçadas et in altitudine de II vel circiter cum uno portali, et etiam cooperuit furnum in villa, que omnia suo videre potuerunt decostare CCC florenos ${ }^{44}$.

\section{Capítol 7. De les reparacions $i$ refeccions d'edificis $i$ heretats realitzades pel Castellà.}

1. Fra Dalmau Dezcoll. Sobre la materia del VII ${ }^{\circ}$ capítol. Dixo que sabe que en el Castiello de Miravet et baylia los adobos o reparaciones etc. que se siguen son feytos del tiempo desti Castellán. Primo, que ha feyto la capiella de Sant Miguel. Ítem cubiertos dos stablos de nuevo. Ítem una gran casa por pallar. Ítem ha feyto el primer portal de la barbacana a guisa de torreta. Ítem dos troços de muralla en la dita barbacana. Ítem en la porqueria, un palomar. Ítem cubrió un gran troz de corredor o perche dentro del castiello. Ítem cubrió de nuevo la torre

${ }^{43}$ Aquest punt de la declaració del testimoni relativa a les obres fetes a la fortalesa templera d'Ascó abona que el Castellà Roiç de Moros residia a temporades en aquest castell i així queda també confirmat per declaracions d 'altres testimonis.

${ }^{44} \mathrm{ACA}$, Cancelleria, Processos en volum, lligall 47, plec A, fols. 130 v.-146 r. 
ques clama de la Reyna. Ítem la cambra de los atzembleros cubierta de nuevo. Ítem que ha plantada de nuevo aquí cerqua del castiello de Miravet una grant vinya que son cerqua $\mathrm{CCCC}^{\text {as }}$ peonadas de greg et de otras muytas plantas. Ítem ha obrado unas casas al Genestar en las quales ha feyto cillero e graneros que non di havia pont. Et feytos cubos e botas para meter el vino de las rendas de allà. Ítem a Rasquera ha compradas unas casas por poner las rendas e hay comprado cubo e botas para'l vino. Ítem a Corbera ha comprado las casas sobreditas. Ítem tiene muyto bien reparados los baxiellos del dito castiello.

24. Blai de Lihori. No sabe que reparacion alguna haya feta en el Castiello de Gandesa, de los otros no lo sabe.

67. Fra Salvador de Luna (...) In castro de Gandesa, de tempore istius Castellani, vidit cooperiri aliquas cameras dicti castri, signanter cameram turris et domum seu tectum penonis, quarum reparationum valorem ignorat.

Furnos autem omnium locorum preceptoriarum Castellani jamdicti, quos, demptis furnis Gandesie, Corbarie et Batee, ipse, cum inde recipiat omnes redditus, teneatur manutenere, prout audivit, sunt in statu dirucionis.

\section{Capítol 8. Del valor de les rendes de les batllies de la Castellania.}

1. Fra Dalmau Dezcoll. Et dixo que las rendas de la baylia de Miravet valen tanto agora como fazian en el tiempo quel dito Castellán entró en la dita Castellania. Et que las rendas d'ella non son diminuydas. En tiempo passado esti Castellán ha arrendadas todas las rendas sin lavores de todas sus cambras a ciertos Ciudadanos de Barchalona, de los quales la uno se clama Anthoni Çaplana, por precio de VIII ${ }^{\mathrm{M}} \mathrm{D}$ florins d'Aragón por cascun anyo.

47. Fra Salvador de Luna. Dixo que esti senyor Castellán trobó la comanda de Miravet en valor o extima de XL mil sols. et la de Azcon en extima de XX mil sols jaqueses e en aquello mismo se estan hoy.

61. Frater Gundisalvus de Funes, prior Cathalonie. Interrogatus per Michaelem de Lobera, rectorem de Maella, commissarium ad infrascripta.

Respondet quod, quando dictus Castellanus fuit ad Castellaniam promotus, comanda de Miravet valebat in tota recepta, secundum communem famam que erat inter fratres dicti ordinis, IIII milia D floreni vel circiter, nunch autem, audivit, valet IIII milia floreni. Et dixit quod valet minus quare dictus Castellanus dedit aliqua membra dicte comande aliis personis, videns Castrum de Nonasp Fratre Salvatore de Luna, Algás et las Pinyeras Fratre Guillermo de Galliners, etiam qui recesserunt de locis dicte Comande de Miravet tempore dicti Castellani. Comanda de Azcon dicit quod audivit ut supra, valere solebat II milia et D floreni, nunch autem non valet tantum.

62. Fray Pascasio Martín. Dixit quod Comanda de Miravet valere solebat, tempore provisionis facte Castellano moderno de Castellania, L mille solidos et hoc scit quia idem testis fuerat familiaris predecessoris immediati dicti Castellani et interveniebat in compotis suis. Modernis autem temporibus non valet ultra XLIIII vel XLV ${ }^{\mathrm{M}}$ solidos, et hoc ideo quia dominus noster dedit Fratri Guilermo Gallines, comendatori de Casp, loca de Algás e de les Pinyeres, que sunt membra dicte comande, valentia IIII mille solidos annuales. Castellanus vero modernus dedit Fratri Salvatori de Luna locum de Nonasp, et locum de la Pobla dedit Fratri Dalmacio Dezcoll, que sunt membra eiusdem comande, valentia II mille solidos annuales. 
Comanda vero de Azcon solebat esse in communi extimatione inter fratres ordinis valere $\mathrm{XX}^{\mathrm{M}}$ solidos jaccenses et tantum credit quod valebat tempore quo Castellanus modernus recepit ipsam Castellaniam. Ideo quia dictus testis fuit familiaris Fratris Johannis Ferdinandi de Heredia, Magistri Hospitalis, qui huiusmodi comandam tenuit aliquo tempore ad manus suas, et ipse testis interveniebat in compotis... nunch vero valet XVII vel XVIII mille solidos. Et hec ideo quia Castellanus modernus dedit loca de Ribaroja et de Berruz... Fratri Guillermo Joli, valentia II mille vel III mille solidos annuales.

\section{Capítol 9. Del manteniment $i$ bon estat de les finques $i$ conreus.}

1. Fra Dalmau Dezcoll. En esti Castiello de Miravet ha quatro vinyas, de las quales el dito Castellán ha plantado una desusso scripta, las otras III ha visto que son mal custodidas, que ha dos o tres anyos que no se son cavadas. Et mas dixo que los olivares que son del dito Castellán non se acostumbravan laurar. Es verdat que ha visto quel dito Castellán los ha feyto laurar, qui una vegada, qui dos, depués qui él es Castellán. Et mas dixo que las otras tierras que son en mano suya o de otros, a quien las ha dadas a cierto tiempo al tierço del grano e al quarto de la palla, que son bien laurados. Dixo que él sabia esto por tanto quel testimonio, stando et regiendo el dito Castiello de Miravet lo havia assin visto.

3. Fra Joan Emperador. Dixo que el senyor Castellán hi ha tan grant affeccion en conrear las como si de aquellas solas devia vivir. Et ha lo mostrado que de nuevo ha plantado de su tiempo $\mathrm{CCCC}^{\text {as }}$ peonadas de vinya, e es cerca de tapia. Et que todas las vinyas del dito Castiello son stadas bien conreadas de mandamiento del dito senyor Castellán por mano del dito senyor Castellán, sino la vinya appellada de Argoles, la qual ha un anyo que no se cavó porque es tan vella que la quieren arrancar et plantar de nuevo. Et otra clamada de la Ribera, la qual no vale nada e no si puede fer buen vino.

24. Blai de Lihori. Et dixo que sabe que en el término de Gandesa, cerqua los muros, el orden havia una vinya que es cerqua de LXXX peonadas, la qual ha visto quel senyor Castellán que hoy es, porque era vella, fízola arranquar cerqua las dos partes e hala plantado de nuevo, e sta bien conreada.

30. Fray Antonio Sánchez. Sabe que ciertas tierras que son en el monte d'Azcon, clamadas la partida de Vispella, de las quales toman décima e vulgarment se dize la décima de Sant Pedro del dito Castiello, las quales son en pocha valor, ço es, un honaz poco más o menos.

Capítols 10, 11 i 12. Dels maltractaments del Castellà als vassalls de l'Orde de l'Hospital i fugida d'aquests de la Castellania per escapar als maltractaments $i$ abusos.

1. Fra Dalmau Dezcoll. Dixo que de Miravet ne de Beniçanet ni del Genestar no sabe que algun vassallo por maltractamiento ende falga. Et mas dixo que del lugar de Rasquera no sabe que alguno sen sea ydo, sino que ha visto que tres vassallos de Rasquera se son feytos vezinos de Tortosa. Empero tienen ada casas e stan en Rasquera, los quales han nombre Ramon Samsó e Guillermo de la Vall e un fil d'En Huguet. Dixo quel fillo den Huguet non sabe que por maltractamiento del Castellán se fiesse vezino de Tortosa. Los dos otros hombres dixo que 
se fizieron vezinos de Tortosa porque el Castellán los forçava que fuessen curadores del un pupillo fillo den Bernat Balldeloset, et mas dixo que de Ramon Samsó et procurador del Castellán, quis clamava P. de Godenys, havia ovido de ponición XXX florines, empero no sabe por qué era la ponición. Et mas dixo que de Gandesa se era ydo a Tortosa Albert Steve, baylle que era de Gandesa porquel dito Castellán li posava o feya processo que havia preso robas de un capellán de allí qui era muerto, et dize que ha oydo dezir quel dito procurador del Castellán havia hovido por composición CC florines. Et mas dixo que ha visto que de Gandesa se era ydo En Bertolí de Mollons al lugar de Cherta, (...) e que muytos otros hombres de Gandesa, los nombres de los quales no sabe, se son feytos vezinos de Tortosa e de Alcaniz e de otros lugares, la razón por qué no lo sabe. Et mas dixo que ha visto que de Batea se son ydos e feytos vezinos de Tortosa Benet Anglí et dos fillos den Aguilló et otros, los nombres de los quales non sabe. De los otros lugares de la baylia de Miravet no sabe que sen sian ydos algunos. Et dixo que non sabe si los sobreditos hombres se son ydos o feytos vezinos d'otros lugares por culpa del Castellán o de sus fillos o de sus officiales, procuradores o servidores (...) Empero que bien pensava que si culpa hi havia que era del dito procurador P. de Godenys. Et que sto pensava porque tal es la fama común en la Castellania.

Et dixo que li acuerda que havia oydo dezir quel Castellán havia hovido de un moro calderero d'Azcon cierta suma de dineros, no sabe quantos. Et esto havia oydo dezir al moro mismo e a muytos otros... Et dixo quel Castellán havia hovido los ditos dineros por razón quel dito moro havia encobrido un cativo moro de un hombre de Tárrega... Et, fecha la dita punición, el dito calderero sen fue con su casa a Lérida, oy no sabe a do s'es...

Interrogado si sabia quel dito Castellán huviesse sentencido a muert l'Alcayd de Azcón. Et dixo que lo sabia, quel rocegaron e scuarteraron en Azcón e esto sabia porque lo havia oydo dezir a muytos de casa del dito Castellán e a otros. Et también havia sentenciado a muert un cristiano, lo qual se clamava Johan Muntanyes, lo qual stava a soldada con el dito Castellán por el officio de la lavor, el qual fue enforcado allí mismo. Et la razón por la qual sentenció a muert los sobreditos, segunt se ha oydo dezir a muytos, que porque querian matar al dito Castellán o metzinas o fetillas. Fizo el processo Johan Sivil, notario, habitant en Sant Per de Calanda, et fue assessor Guillem Enveja, lo qual habita en Montblanch. Los bienes del dito Alcayde vinieron a mano del dito Castellán e del dito su procurador... e fizo donación a Pero Roiz de Moros, su fillo. Él sabe que el hermano del dito alcayde fue preso e que murió, mas si murió en preson o no que non lo sabe.

Interrogado si sabia quel senyor Castellán fiziesse obligar a un hombre que dizien En Carcases de Gandesa a ciertos judíos de Falset por vigor de una letra de creyença del dito Castellán. Et dixo que no lo sabe sino por relación del dito Carcaçes.

No sabe que los fillos, servidores, officiales, religiosos o seculares, hayan fecho algunas violencias, otros malos tractamientos corporales o injurias a moros o cristianos, o forçadas mullers de la dita baylia de Miravet o de las otras cambras.

13. Mahoma Algordell, moro de Beniçane. Sabia quel dito Castellán tuvo en presones Alfoma, muller que fue del alcaid de Azcon aprés la muert del dito su marido, el qual fue sentenciado por el dito senyor Castellán, de la qual muller el dito Castellán huvo por liurarla de las presones MD florins, porque se huvieron a vender o alienar los bienes de la dita Alfoma e de dos fillos que ella havia havidos antes de otro marido, por la qual razón la madre e los fillos son fora de la terra del Spital e estan huy en Benifallet (...) Et mas dixo que sabia que una muller mora, qui stava presa en Miravet por algunos delictos que li eran imposados, fue 
condempnada en LXXX açotes. Et las aljamas de Miravet e Beniçanet querian redemir los ditos açotes a XII dineros por açot segunt que era antigament costumbre entre'l Spital et las ditas aljamas pus que no sian açotes de turment. Et mas es pacto reduzido entre esti Castellán qui oy es et las ditas aljamas segunt el testimonio ha deposado de que tomó CCC florins. Et Pero de Godenchs, procurador del dito senyor Castellán queria que la dita mora recebiesse los ditos açotes (...) Et durant esta controversia, la dita mora sende fuyó. Et el dito Pero de Godenchs instava que la dita mora fuesse tornada a la preson. Et las ditas aljamas, no podiendo haver la dita mora, por redemir su vexación hovieron de dar al dito Pero de Godenchs... cient florins ${ }^{45}$.

20. Pero Aulea, de Rasquera. Dixo que Na Guiamona quondam muller de Domingo Bernat de la Vall, que porque un cunyado suyo, Guillermo de la Vall, el qual stava con ella, dixo al $\operatorname{sach}^{46}$ del dito lugar "Morro de Vaquas", le fizo pagar el Castellán LXX florins d'Aragon. Et mas dixo que a Bernat Vandellòs, porque screvió la ordinacion de Bernat Vandellòs qui stava a la muert e noy havia notario, fizieron li pagar XL florins. Et que Bernat Brull, del dito lugar, trobó en un blat suyo dos cabras e ligólas a una mata et fizieron li pagar por aquellas L sueldos diziendo que havia usurpada jurisdiccion. Et Domingo Martin, de qui eran las cabras, porque ende escorchó una de las cabras que trobó muerta, fizieron li pagar X lliuras diziendo que havia usurpada jurisdiccion ${ }^{47}$.

22. Guillem Canalda, del Pinell. Primo fue interrogado sobre los X, XI, XII capítolos. Et dixo que li acuerda que a un hombre clamado Guiamó Ponç, del dito lugar, porque dezian que era ydo a la puerta de una dona casada, hija den Ramon Morera, del dito lugar, Fr. Dalmau Dezcoll, regidor del Castell e baylia de Miravet per lo dit senyor Castellàn, tomó preso lo dito Guiamó e fizo li procés a la conclusió antes que pudiesse sallir de la dita presó se huvo a composicion con el dito regidor por trenta florins, los quales fueron pagados al dito regidor cerqua ha de II anyos por manos del dito testimonio. Aparesce a ell, testimonio, quel dito processo fuesse injusto por tanto quel testimonio conoscia bien al dito Guiamó, el qual era hombre de buena fama e por tal era reputado en el dito lugar. Et nunqua se supo que antes ni aprés el dito Guiamó tocasse la dita muller ni hubiesse que partir con ella, sino que, una tarda, el dito Guiamó, estando en la carrera delant la puerta de la dita muller, la dita muller vino con su hermana de casa de su padre et trobó al dito Guiamó en la dita carrera delant su puerta sin fazer otra cosa. Et sobre esto fue puesto al dito Guiamó que por la dita muller hi era, e otra cosa no hi huvo. Et que por esto, el dito Guiamó, sintiéndose maltractado, sen fue a estar a Cherta con todo lo suyo..., do hoy sta.

Et dixo que a él, testimonio, acuerda que, cerqua ha de XVIII anyos passados, el dito Fr. Dalmau, stando regidor del dito castiello, porquel testimonio no quiso consentir que una pupilla cosina germana del testimonio fuesse muller de uno que queria el dito Fr. Dalmau, tuvo preso a ell, testimonio, en la ciga del Castiello de Miravet XXVII jorns en tiempo de Paschua florida, de que el testimonio se sintió e siente por agreviado ${ }^{48}$.

\footnotetext{
${ }^{45} \mathrm{ACA}$, Cancelleria, Processos en volum, lligall 47, plec A, fols. 35 r.- 38 v. ${ }^{46}$ Saig.

${ }^{47} \mathrm{ACA}$, Cancelleria, Processos en volum, lligall 47, plec A, fols. 45 v. $-47 \mathrm{r}$.

${ }^{48} \mathrm{ACA}$, Cancelleria, Processos en volum, lligall 47, plec A, fols. 48 v. -50 v.
} 
24. Blai de Lihori. A la universidad de Gandesa son stados feytos todos los greuges e maltractamientos contenidos en la cédula. Et non los havia vistos fazer en tiempos de los otros castellanes passados, excepto a lo que toqua a los leytos, car siempre ha visto que a los comandadores et frayres les fazian leytos en la villa quando vinian. Empero cada uno dellos fazia como bueno dando alguna cosa a la dona o serventa de casa qui les fazia los leytos e lavava las scudellas. Et excepto las donaciones quel dito Castellán fazie al senyor Rey, etc., car dixo que esto ya Fr. Johan Ferrández de Heredia lo fazia por semblant forma et Fr. Martin de Lihori, quondam castellanes, bien que dezia que era mal feyto. Et por esto el dito Fr. Martin havia havido acuerdo, sino que el qui hoy es Castellán e el que hoy es comendador de Cantavella et Fr. Arnalt Armengol quondam comendador de Valencia hi contrastaron que era bueno que en tales donaciones fuessen presentes ciertos comendadores. Et el dito compartimiento ques fiziesse con aquellos e ciertos hombres buenos de las universidades que deven pagar las ditas donaciones por squivar que sobremesa noy pudiesse seyer feyta por el dito Castellán como se faze cadaldia. Et el dito Fr. Martin murió antes que este acuerdo no se metió en obra.

Et li acuerda que un hombre vezino de Gandesa clamado Ponç Lorenç, porque se yazia con una su serventa et la emprenyó, fue acusado por los amigos de la dita serventa jasia ella no sen querellás. Et el senyor Castellán o sus officiales tomaronlo preso et pusieron lo en la torre del Castiello de la dita villa, no pas en la preson comuna. Et no sabe que processo alguno le fuesse feyto. Et antes que no sallió de allí huvo se acomponer con el dito senyor porque salliesse de la preson en CCC florins, los quales li pagó e los huvo a manlevar de judios et por aquellos entró en fiança Domingo Vall, vezino de Gandesa, cosino hermano del dito Ponç. Et aprés pocos dias el dito Ponç sallióse de Gandesa e de toda la terra del orden et nunqua mas hi es tornado, antes es muerto en Alcaniz. Et sabe esto por quanto él entrevino en rogar al dito senyor que lo remetesse a la preson comuna. Interrogado si sabia que la dita servienta huviesse los ditos CCC florins o partida d'aquellos et dixo que no sabe ni ha oydo dezir que ende ella huviesse malla.

Et mas dixo que li acuerda que un hombre de buena fama e reputacion en la villa de Gandesa e sus circumstancias, al quel dizian Ramon Vallés, qui era stado jurado de la dita villa, fue diffamado que él havia sacado o furtado del blat quel senyor Castellán de sus rendas tenia en una botiga del alberg del dito Ramon. Et por esto el dito senyor Castellán tomó preso al dito Ramon e fízoli processo... bien que en la dita villa fue pública fama que era injusto, e el dito Ramon, quisiendo sallir de la preson, compuso con el dito senyor Castellán en D florins, los quales pagó al dito senyor segunt havia oydo dezir al dito Ramon. Et por aquesto el dito Ramon tomó tan grant ira que tornó loco e tal es muerto. Et dixo que Vicent Gironés o Bernat Vidal eran notarios del dito processo porque eran notarios de la dita villa. Et el dito Ramon, veyendo se assin maltractado, se sallió de la terra del orden et sen fue con su casada a estar en Tortosa.

Et dixo que le acuerda que cerqua ha de $\mathrm{X}$ anyos passados que murió un clérigo en Gandesa, clamado Domingo Johan, et fizo su testamento, en el qual lexó lo suyo a un su nieto clamado Ramon Monpahó. Et el dito senyor emparó los ditos bienes diziendo que aquellos, pus eran de clérigo, a él se pertanyian. Et por redemir los al dito nieto compuso se con el dito senyor en XXX florins, los quales pagó al dito senyor. Et mas sabe quel dito nieto manlevó los ditos XXX florins de judio ende pagava usuras, no sabe quantas ni a quién, e assin es fama pública en la villa.

Et dixo que sabe que uno que era alcadi d'Azcon, clamado Amaduz, present ell, testimonio, en el Castiello de Azcon, fue por el dito senyor o por su assessor sentenciado que 
fue rocegado e spunyado en cierto lugar e li dassen a beure metall fuso e squarterado. Et assin fue feyto, present et veyent el testimonio. Et acuerda a ell, testimonio, que el dito alcadi, depues la sentencia leyda, cridá et dixo tales o semblants palauras oblas Que diablos sen lieven la mi ánima si en las cosas que m'an posadas yo mir mal. Interrogado si sabia por qué causa el dito Castellán lo sentenció a muert. Et dixo que solament li acuerda que hoyó dezir que porque li havian puesto quel dito alcadi queria dar al dito Castellán metzinas e havia feyto ymágines con las quales matasse al dito Castellán.

(...) Et dixo que li acuerda que cerqua ha de unos $X$ anyos que uno clamado Fr. Barthomeu Prades del dito orden se enforquó en Gandesa en su casa que tenia en la dita villa. Et el dito senyor Castellán tomóse sus bienes et dio con consentimiento del capítol de la Castellania a Johan Navarro, su servidor.

25. Ramon Jover, veí de Gandesa. Dixo que li acuerda que cerqua $V$ anyos fue fama en Gandesa que un capellán, al qual dezian Johan Claret, se enforcó e En Guiamó Pujo, son cunyat, et Bernat Salvetat, fillo de su hermana, desenforcaron lo et depués dixeron quel havian trobado muerto. Et el dito senyor Castellán dixo que estos havian errado et por esto tomólos presos et túvolos bien cerqua dos meses et fazíales processo et antes que non si dio sentencia composieron con el senyor Castellán en CC florins, los quales pagaron, e de la muert del dito capellán... e lo que fizieron en desenforcar, lo fizieron porque la senyoria no se encarregasse en los bienes del muerto.

Et dixo que cerqua ha VIII $^{\circ}$ a VIIII ${ }^{\circ}$ anyos que fue fama que Ponç Lorenç, vezino de Gandesa, se gitava et emprenyó una su sirvienta jatsia en el acto no fuesse trobado. Et por esto Johan Navarro, bayle por el dito senyor de la dita villa, tomólo preso et començó li processo et el dito Ponç compúsose con el dito senyor sin sentencia en $\mathrm{CCC}^{\text {os }}$ florines, los quales li pagó e manlevó de judios de Falcet a usuras e, ultra aquellos, dio a la dita sirvienta XXX florines con que fuesse casada. Ell, testimonio, entendia quel dito Ponç fue maltractado en esto, car parece li, segunt la población de la dita villa es, que hombre que yazia con fadrina, si no la tomava 0 no la podia tomar por muller, que li dasse con que otro la tomasse tanto quanto el padre pue dar a la dita fadrina, et sabe quel padre de la dita sirvienta apenas li podia dar X lliuras. Axí que pues el dito Ponç li dava XXX florins, con esto devia esser quito.

Et mas dixo que Ramon Vallés, acusat que havia robado blat et oli de la botiga que era en su alberg, la qual tenia logada Anthoni Dusay, procurador del Castellán, et tomaron lo preso en cadenas et grillons. Et el dito Ramon, veyéndose assin injustament maltractado, tomó en si grant tristicia e con aquella es muerto quasi ensensat. El dito Ramon se sallió de la terra del Spital e sen fue a estar a Tortosa et aprés, a consellos de metges, tornó en Gandesa e allí murió.

Et mas dixo que en la villa de Batea, entre los de la universidad de Batea havia question et lo senyor Castellán fue allí et aviviólos et dióles licencia que fiziessen un molino de olio et que issen a moler do se quisiessen. Et por esto huvieron li a pagar $\mathrm{DCCC}^{\text {os }}$ florines et esto sabe porquey entrevino et lo ha oydo dezir a los de Batea.

Et dixo que un hombre de la Fatarella, clamado Calonge, fillo den Berenguer Calonge, porque se yasia con una su sirvienta, fue tomado preso. Et depués fue dado a capleuta de $\mathrm{D}^{\text {os }}$ florins et entraron fiança el dito padre e uno a qui dizen Altisen e un otro del dito lugar. Et aprés fue dado a entender, el testimonio no sabe por quién, al dito fillo quel senyor lo enforcaria. Et él, todo amedrado, fuyó del dito lugar e de toda la terra del Spital. 
26. Bernardus Vitalis, notarius Gandesie (...) Et mas dixo que li acuerda que un hombre clamado Pero Lobet, scudellero, qui sta en Gandesa, fue posado que havia antes otra muller en Cathalunya et quende havia tomado en Gandesa una, et por esto tomaron lo preso, et antes que salliesse de la preson compúsose en XXX florins, los quales pagó, et segunt oppinió del testimonio et d'otros, atés que era hombre de buena vida et conversación, creyen que injustament li levaron los ditos XXX florins.

Ítem dixo que li acuerda que un hombre del lugar de la Torreziella ${ }^{49}$ vino en Gandesa por menar sen su muller que era folla, que se era ida. Et porque la sen menava e ella cridava. Et fue preso et antes que salliesse de la preson pagó diez florins al senyor.

30. Fray Antonio Sánchez. Dixo que ha oydo dezir que an Berenguer Feliu, bayle de Camposines, porque havia comprados VIII moltons de un moro que se dezia haver los furtados, jatsia quel dito Berenguer los comprás en la plaça de Camposines palesament et se proferia mostrar emptor et qui le los havia vendidos, el dito senyor Castellán lo tomó preso por cierto tiempo en el Castiello d'Azcon et lo fizo rescatar en XXX florins et tres florins al asessor, lo qual era en Borrell (...) Empero sabe quel dito Berenguer era hombre de buena fama e de buen testimonio e servidor del orden. Et por esto creye que la dita universidat li fue presa injustament.

31. Pere Figuera, veí d'Ascó. Interrogado si sabia quel alcayde que solia seyer de Azcon, clamado Fomaduz de Cayt, fuesse preso e sentenciado a muert por mandamiento del dito senyor. Et dixo que lo sabe car viólo saliendo del castiello de Azcon rastrar, despunyar, scabeçar, squarterar e enforcar et cremar las minucias e li dieron metal fondido a bever. Et dixo quel testimonio hoyó legir la sentencia en la puerta del dito castiello an Guillem Enveja, asessor del dito senyor. Et eran allí presentes el comendador d'Orta e otras muytas gentes. Et sabe quel dito senyor Castellán la hora era dentro del dito castiello. Et dixo quel dito alcayde era hombre de buena fama e de buena conversación segunt moro. Et dixo que es ver que era diffamado de fembras et que alre el testimonio noyde sabia. Interrogado si sabia el dito testimonio que, antes quel dito alcayde fuesse preso, en otros tiempos en antes fuesse diffamado de fer ymágines, fetillas, metzinas ni otras malas cosas que viniessen en danyo del dito Castellán ni otro ninguno, et dixo que no lo sabia ni havia hoydo tal cosa. Et sabia que la muller del dito alcayde fue presa ensemble con su marido, e aprés muert de aquel ${ }^{50}$.

32. Calema Caxeres, moro d'Ascó (...) Et dixo que el testimonio, quando se dio la sentencia (contra l'alcayde Fomaduz de Calim), el testimonio era present a la puerta del castiello d'Azcon, la dita sentencia se dio por En Aguiló, baylle qui era d'Azcon, et leyóla en Guillem Enveja, assessor del dito senyor Castellán. Et fazíala executar el Comendador d'Orta, presentes muytas gentes, et el dito senyor stávase dentro en el dito castiello d'Azcon. Et dixo que sabe que la dita Alfova, muller del dito alcayde, viviendo e stando preso el dito alcayde e aprés su muert, stava presa grant tiempo en el dito castiello. Et querian la rodar, e ella dixo que era prenyada, e el testimonio, qui lahora era alcayde de Azcon, de mandamiento del dito senyor envió hi IIII mulleres, dos moras e dos cristianas, por veyer si era prenyada, las quales conexieron que lo era. Et la hora la dita Alfova compuso se por MD florines, los quales pagó antes que salliesse

\footnotetext{
${ }^{49}$ Torrecilla de Alcañiz.

${ }^{50} \mathrm{ACA}$, Cancelleria, Processos en volum, lligall 47, plec A, fols. 73 v. -75 v.
} 
de la preson. Et dixo que algunos moros se eran ydos d'Azcon... car Ferig Alfadet e Fomat Alfadet, germans, sen fueron a estar a Flix, diziendo que porque havia servido al Castiello e non havian quesido pagar. Et el otro porque li prendieron la muller acusada de adulterio en Miravet $^{51}$

33. Fra Miquel de Penya. Et dixo que sabe que fizo prender a Fomaduz de Zalim, alcayde de Azcon, et lo vio en la preson en el dito castiello et fue present quando fue sentenciado a muert por el baylle, qui la hora era por el dito senyor d'Azcon, clamado En Aguiló, et fue leyda la sentencia por En Guillem Enveja, assessor del dito senyor, et executada por el comendador d'Orta, e testificada por Johan Sivil, notario, en la puerta del dito castiello, do el senyor no era present, mas stava en las finestras del castiello mirando lo que se fazia Et dixo quel dito alcayde fue rastrado, spunyado, scuarterado, enforcado et cremadas las minucias, et le fue dado metal regalado a bever. Interrogado el testimonio quende presumia o qué fama era entre las otras gentes fora casa del dito senyor. Et dixo que su presumir era dubitativo en quanto vedia quel dito senyor e otros cristianos queyde cabian lo condempnavan a muert. Et d'otra part, un dia antes quel dito alcayde fuesse sentenciado, el dito alcayde stando en la preson e él, testimonio, con él faulando solas, li dixo "Fray Miguel, si Fray Alamán de Foxá fuesse aquí sé que aquel no me falliria jatsia que todos los otros amigos m'ayan fallido. Yo sé bien que cras he a morir, demando vos yo si he a seyer cremado o inforcado." Et el testimonio dixo que fiasse en Dios que encara entro adaquella hora excitaria adalguno que pregaria por él, et l'alcayde dixo "Ay, Fray Miguel, quando entro adagora se son adormidos, ya entro en la manyana no se excitarán. Ara, Fray Miguel, yo sé que he a morir porque yo sé que vos avez grant amistat con Fray Alamany de Fuxá, comendador de Monçon, priego vos que cada que vendrá de Sicília, do es, en secreto vos le digays estas palauras que yo us diré que si yo he culpa en las cosas que me son apposadas, por las quales yo muero, que diablos se lieven la mi ánima yasia que por fuerça de turmentos lo contenido en el processo que me han feyto me hayan feyto atorgar. Et esto yo entiendo a dezir delant todo el pueblo antes que muera." Et vio el testimonio que, de feyto, el dia que fue sentenciado, encontinent leyda la dita sentencia, el dito alcayde començó a parlar e no lo lexaron parlar, cuytándolo que isse adelant. Et por las razones sobreditas el testimonio no puede presumir cierta cosa.

Et dixo que quanto a la fama pública que era entre los de la aljama de Azcon, que duptavan que esto fuesse verdat. Et dixo que sabia quel dito alcayde era turmentado por tanto que muytas vegadas el testimonio entrava a do lo turmentavan a pregar por el dito alcayde, et gitavan londe e oya lo clamar grandes gridos quando lo turmentavan et assin lo oyó dezir a los quey eran presentes. Empero el testimonio no sabe certament quantos turmentos li dieron. Interrogado si sabia o ha hoydo dezir quel dito alcayde, de continent que era decendido del turment, recibiessen su confession. Et dixo que oyó dezir a Johan Sivil, notario del processo, que tenian esta manera, que tan continent como decendia al piet del turment, lo interrogavan e scrivian su confession e aprés metian lo en otra cambra et leyan li la dita confession que havia

${ }^{51} \mathrm{ACA}$, Cancelleria, Processos en volum, lligall 47, plec A, fols. 75 v.-77 r. 
feyta. Et si non perseverava en ella, cancellavan la e tornavan lo al turment, et si perseverava, consunian la en el processo ${ }^{52}$.

34. Montoliu Izmail, moro d'Ascó. Dixo que sabia quel dito senyor Castellán, cerqua ha de VI anyos, mandó metre en preson a Ovelle Decat, moro de Azcon, porque era fama que se gitava con una mora viuda de Azcon...

Dixo que sabia que la dita Alfova, temiendo, de nueyt miso se en un leut e por agua fue sende a Benifallet, terra del Rey, do sta con sus fillos. Et dixo que él, testimonio, vio preso el alcayde d'Azcon Fomaduz de Çat de Calim et lo vido rastrar, etc. e enforcar en diversas partes los quartos e cremar las minucias ${ }^{53}$.

36. Francesc Aguiló, veí d'Ascó (...) Et dixo que él, como baylle que era de Azcon, sabia quel senyor Castellán fizo prender a Ovelle, que fauló con el dito Ovelle muytas vegadas stando preso en el Castiello de Azcon et fue tractador entre el dito senyor e el dito Ovelle por avenir los quel lexasse de la preson et que li sembla, jatsia non li acuerda perfectament, quel dito senyor li demandava II mil florins e el dito Ovelle len doná mil et que no se podieron avenir e quel dito Ovelle morió en la preson e, muerto que fue, lo tragueren de la ciga e lo meteren en un patio fora del castiello, do stuvo II o III dias et los parientes o la aljama de Azcon pagavan a ciertos hombres quel guaytassen. Et aprés, segunt havia oydo dezir a muytos... pagaron $\mathrm{V}$ florins a la senyoria e lexaren lo soterrar.

Et dixo que Fomuz, alcayde de Azcon, fue preso porque era diffamado seyer fetillero e metzinero contra la persona del senyor Castellán, et sobre esto li fue feyto processo. Et dixo que, aprés pochs dias, fue preso otro, clamado Johan Muntanyes, cristiano, servidor antigo del dito senyor Castellán, el qual testificó en su deposición un dia era ydo a casa del dito alcayde e dixo que sternís un cafiz de civada. Et aprés dixo el dito Johan "Mal viatge he feyto, que con esti senyor he perdido mi tiempo VII anyos e res non puedo haver." Et dixo quel dito alcayt li dixo "Si tu te quieres, yo te daré recaldo." Et fizo lo jurar sobre un libro de tener lo secreto. Et dixo "Fes me venir Fomaduz, mi nieto." Et, venido Fomaduz, dixo li l'alcayde "Fes dos ymagines de cera, la una a semblança del dito senyor Castellán e la otra a semblança del dito Johan, e ya sabes qué has a fazer." E, aprés, feytas las ditas ymagines, metieron las el dito Fomaduz e el dito Johan en lo camí del Xurcu segunt el dito Johan dizia. Et veyendo quel dito senyor havia mudado camin por otra part, una nueyt mudaron las en el camino cerqua de Miravet, segunt estas cosas e otras más largament se contienen en el processo del dito Johan. Et a l'alcayde dieron turment en las manos. Creye que l'alcayde fue sentenciado a muert justament. Et dixo que en quanto el dito Johan Muntanyes lo testificó e sen lexó morir, creye que l'alcayde fue sentenciado a muert justament, car a la fin el dito Johan, quando lo metieron en la sarria por rocegar lo, dixo tales o semblants palauras "Pero Roiz, Dios vos lo demande en la ánima si no me vengays d'aquellos traydores que m'han enganyado." Et entendió el

${ }^{52}$ Segons el testimoni declarant, la muller de l'alcaid processat, Alfova o Alfoma, un cop alliberada de la presó, era obligada pel Castellà a pagar 3.000 florins; d 'aquests, van pagar-ne 500 els seus fills tinguts del seu primer matrimoni. Segons el declarant, "la dita Alfova es fora de la terra del orden e está hoy en Benifallet con sus fillos. Et ha oydo dezir que en Beniçanet, en las casas de los ditos fillos de Alfova, havia una ciga en 1 'establo, do dizen que havian gran quantitat de panes de arambre, los quales se priso Pero de Godenchs assi como a procurador del dito senyor". ACA, Cancelleria, Processos en volum, lligall 47, plec A, fols. 77 v.- 81 v.

${ }^{53} \mathrm{ACA}$, Cancelleria, Processos en volum, lligall 47, plec A, fols. 81 v.- 83 v. 
testimonio que lo dizia por el alcayde e su nebot. Interrogado si sabia quel dito alcayde, dada la sentencia, dixiesse "que diablos sen levassen la su alma si en res que él havia confessado él era culpant". Et dixo que, decendiendo por la costa del dito castiello e indo a sentenciar, el dito alcayde dixo las ditas palauras altas que muytos de los qui eran allí las podieron oyr. Et dixo quel dito alcayde se levantó e quiso faular e començó a dir "Senyores", e de continent fue soptado, que non lo quisieron jaquir faular; qual o quales personas lo soptaron, et dixo que Sancho d'Espeio, scudero del dito senyor, dixo "Avant, avant", et assin tothom se mogué et dixieron "Avant, avant".

Et dixo quel dito Johan Muntanyes fue preso e sentenciado a muert por las ditas fetillas o metzinas. Et confessó mediant turment de cordas en los braços. Antes quel dito Johan fuesse preso, el testimonio hoyó dezir que havia faulado con dos fadrinas moras de casa del alcayde que eran presas en el dito castiello diziendo les que ellas ques guardassen que no dixiessen res de lo que sabian, e dizian que por esto lo havian meso en preson, jatsia estas palauras no sian en el processo. Et dixo que al dito Johan fue dada sentencia que fuesse rocegado, despunyado e enforcado por el coll e assin fue feyto. Et al dito alcayde fue dada sentencia que fuesse rocegado, despunyado e que li dassen a bever metal fundido e que fuesse squarterado e cremadas las menucias e penjados los quartos en ciertas partes ${ }^{54}$.

37. Duran Albert, veí de la Fatarella (...) Dixo que sabia que un hombre de la Fatarella, clamado Berenguer Calonge, fue diffamado haver usado con una fadrina, que stava con el dito Berenguer, contra natura, el qual fue preso et caplevado en D florins. Et aprés fue clamado a Gandesa, do era el dito senyor Castellán, e fue allá. Et havia oydo dezir an Guillermo Enveja, assessor del dito senyor, quel dito Berenguer havia confessado, present el dito senyor, el dito delicto, jatsia ell, testimonio, huviesse oydo dezir a Berenguer Calonge, padre del dito delado, e a Francesc Calonge, oncle del dito delado, que la dita confession havia feyta porque el dito assessor havia dito al dito delado que, o lo haviés feyto o no, que él lo atorgás e que se metiés en braços del dito senyor, car otrament no podia seyer absuelto. Et aprés feyta la dita confession el dito delado, sintiendo que otra vegada querian procedir a cabción de su persona, fuyó, e el dito senyor adjudicóse todos sus bienes (...) Es ver, empero, que ell, testimonio, assin como baylle, ensemble con los jurados del dito lugar, fizo guardar la dita fadrina a profembras del dito lugar porque ella se clamava esser forçada por el dito delado contra natura, las quales profembras fizieron relacion ella esser corrupta davant e no de çaga contra natura. Et mas dixo quel testimonio no sabia quel dito delado de semblant vicio fuesse diffamado ni lo oyó nunqua dezir ne era fama en el dito lugar. Et por las ditas cosas el dito delado sen fue estar fora la terra de la Castellania e nunqua tornó.

Et dixo que sabia quel dito senyor Castellán huviesse tenido en presones e mandado sentenciar a muert a Fomanduz Deçat de Calim, moro, quondam, alcayde de Azcon, que un dia el testimonio fue en el lugar de Azcon, do havia un judio de Falcet clamado David Mercadell, el qual judio queria faular con el dito alcayde stando en la preson. Et el dito senyor Castellán no loyde lexava entrar sin que otri noyde entrás con él. Et el testimonio fue mandado por el dito senyor que hi de entrás con el dito judio, e entrá hi de do el testimonio present e el dito judio fauló muyto con el dito alcayde diziendo que se maravellava del que se dizia que havia atorgado las cosas de que era delado e havia de aquellos diffamado su muller e su hermano... Et el dito

${ }^{54} \mathrm{ACA}$, Cancelleria, Processos en volum, lligall 47, plec A, fols. 85 r.- 88 v. 
alcayde dixo "Qué hi faria, car noyde havia podido fazer alre." Dando a entender que por fuerça de turmentos lo havia atorgado, e el testimonio le hoyó fazer muytas juras que él no era culpable en lo que li havian posado. Et mas dixo el testimonio que li dixo el dito alcayde que, un dia, Pero Roiz, fillo del dito senyor Castellán, lo havia apartado en la capiella del dito castiello de Azcon e li havia dito que él atorgás los capítols contra él posados, que él, Pero Roiz, faria con el dito senyor que no temeria de muert et que por esto él lo havia atorgado. Et mas dixo el testimonio que fue en Azcon el dia que la sentencia fue dada al dito alcayde, et quando fue sentenciado e fue al portal de la villa hoyó dezir alta voce al dito alcayde dreçando las palauras a Pero Roiz, dixo "O, Pero Roiz, vos me matades, que otri no lo fa esto, mas diablos me lieven mi cuerpo e ánima si yo he culpa en esto por que muero".

38. Bernat Criviller, veí de Vilalba dels Arcs. Dixo que li acuerda que, algun tiempo ha passado, el dito senyor Castellán perjudicó los privillegios de la universidat del dito lugar de Villalba tomando un hombre del dito lugar, al qual dizian en Pero Roqua, se lo levó preso al Castiello de Azcon e non lo quiso restituir entro que la dita baylia toda fizo fermança al dito senyor en XX mil sols. den Gralla. Et mas Fray Dalmau Dezcoll, regidor del castiello de Miravet, saquó una judia de la preson de Vilalba, la qual era diffamada esser metzinera, et la sen levó contra la voluntat de los del dito lugar en lizión de lurs privillegios, la qual soltó sin que justicia ninguna no sen fizo, segunt fama, por diez florins que li dio. Et dos otras fembras cristianas que eran presas con aquella en Vilalba por aquel mismo delicto fueron sentenciadas a cremar. Et todo esto sabe el testimonio porque es uno de los del consello del dito lugar e hi entrevino.

40. Guillem Folquer, de la villa de Bathea, de XXX anyos entaqua, de edat LXV anyos o cerquantes, jurado. Dixo que la universidat de la dita villa es estada maltractada e singulares de aquella maltractados diversas vegadas assin por el dito senyor como por sus procuradores, bayles e officiales malos tractos metiendo division entre majores e menores cerquando occasiones dius color de reparar e endreçar la dita villa e en otras muytas maneras segunt mas largament es stado dado por una cédula delant nosotros desto dada por part de la dita villa, do aquella es stada formada e assin lo ha visto e oydo como en la dita cédula se contiene. Et mas dixo que por algunos malos tractamientos que los bayles e procuradores del dito senyor han feytos o cominados fazer son idos fora de la dita villa de Bathea e de toda la terra del Spital los mas riquos e mas puxantes de la dita villa. Primero, Perico Aguiló, richo en L milia sols. Et aprés, En Berenguer Aguiló, frare del dito Perico, riquo en bien V mil florines. Et aprés, En Guillem Englí, richo e puxant. Et aprés, Nadal Fort sende fue a estar a Gandesa por onta de Pero de Santa Gadea ${ }^{55}$, baylle del dito senyor en Batea, et de otros a present non li acuerda ${ }^{56}$.

41. Bernat Vilomar, veí de Batea. Dixo que sabe que la universidat de la dita villa e singulares de aquella son stados maltractados assin por el dito senyor como por sus bayles, procuradores e otros officiales faziendo sus bayles, procuradores e oficiales malos tractos, metiendo division entre majores e menores de la dita universidat cerquando occasiones dius color de reparar e endreçar la dita villa dando a entender al dito senyor cosas no lícitas e en otras muytas maneras segunt mas largament es stado dado por una cédula delant nosotros, ditos

${ }^{55}$ Josep Alanyà I RoIG, Llibre de la Mare de Déu del Portal, pp. 47-48, 159-163.

${ }^{56} \mathrm{ACA}$, Cancelleria, Processos en volum, lligall 47, plec A, fol. 92 r.v. 
visitadores, desto dada por part de la dita villa, la qual el testimonio advera cómo aquella e las cosas contenidas en ella sean veras. Et sábelo porque es entrevenido en el consello de la dita villa, do fue feyta, et aquellas cosas assin las ha vistas e hoydas. Entre los otros de los ditos malos tractos que son stado feytos fue que como la dita universidat, por capítol de lur costum, hayan usado que los jurados e conselleros qui regescan en el anyo advenidor, et Pedro de Santa Gadea, baylle por el dito senyor de Batea, se forçó de metre division entre majores e menores, tanto que ajustó grant gent de los menores de la dita universidat dando les a entender que los jurados de algunos anyos passados se havian retenidos de la dita universidat L mil o LX mil sueldos, e con aquesto el pueblo menudo se advolotó et fizieron consello por sí con el dito baylle et eleyeron ciertos conselleros ${ }^{57}$. Et de todas estas cosas informaron el dito senyor no verdaderament. Et por esto el dito senyor vino en el lugar de Batea e tomó los libros de los contos de los anyos passados, de XIII anyos o cerqua, cuydando trobar de lo que era mal informado. Et, vistos los ditos libros, trobó la ignocencia de los prohòmens e jurados de la dita universidat. Et quando vio el dito senyor que en aquesto no havia manera, demanda los que lo serviessen por sus treballos. Et puso por tractador entre él e la dita universidat a Pero de Godenchs, procurador del dito senyor, el qual diversas vegadas los menaçava quel dito senyor ne enforcaria $\mathrm{III}^{\circ}$ o IIII ${ }^{\circ}$ de la dita villa, por que ellos de la dita universidat, más por temor que por justicia ni amor, huvieron a dar al dito senyor DCCC florines, los quales huvieron a manlevar de ciertas personas a interés, que, entre principal, interesses e missiones, puyaon a la dita universidat en bien MCC florines. Et todas las ditas cosas sabia el testimonio porque en aquel anyo, assin como a jurado, entrevinió en todas las sobreditas cosas e assin lo vio. (...5

47. Fra Salvador de Luna. Dixo que sabe que Guiamó Anglí de Batea es ydo a estar a Tortosa por maltractamientos del baylle de Bathea, al qual dizen Pero de Santa Gadea, el qual baylle, segunt el dito Guiamó e otros... han dito a ell, testimonio, que un dia, stando jurado el dito Guiamó e faziendo la guayta levó al dito Guiamó las armas et li fizo otras menaças, e En Periquo Aguiló e En Berenguer Aguiló de Batea, qui sende fueron a estar a Tortosa e En Ponç Lorenç a Alcaniz, no sabe la razón porqué, et n’Albert Stheve que solia esser baylle de Gandesa, sen fue a estar a Tortosa por occasion que Pero de Godenchs, procurador del dito senyor, li fizo pagar CC florins acusándolo que havia robado un capellán de Gandesa en su muert.

65. Dominus Johannes Siurana, prior Ecclesie Dertusensis. Dixit se nihil scire nisi quod, tempore quo dictus Castellanus erat in villa de Batea causa concordandi debatum seu questionem que erat inter maiores et minores post multas altercationes, quod ipsi vassalli concordarunt et obtulerunt liberaliter dare ipsi Castellano $\mathrm{DCCC}^{\mathrm{s}}$ florenos, ipso teste presente, hac conditione adiecta quod permiteret eis facere unum molendinum olei sub certo censu, quem ignorat, solvendo ordini, et quod haberent liberum arbitrium eundi ad molendum bladum quocumque vellent licet alias essent astricti ire ad molendum in molendino de Algás; an autem juste vel injuste fuerit huiusmodi summa DCCC florenorum dicto Castellano soluta, dixit

${ }^{57}$ Guillem Guimerà, de Batea, membre del concell de la vila, un dels testimonis declarants, afegeix en la seva declaració aquesta notícia “... e con aquesto el pueblo menudo se avolotó e fizieron consello e conventículo por su cabo con el dito bayle ensemble e de feyto eleyeron conselleros a la dita universidat poniendo toda la universidat en punto que todos se acultellassen" (ACA, Cancelleria, Processos en volum, lligal 47, plec A, fols. 93 v.- 94 v.)

${ }^{58} \mathrm{ACA}$, Cancelleria, Processos en volum, lligall 47, plec A, fols. 92 v. -93 v. 
credens quod juste tum quia, ipso teste presente, fuit per eos gratiose oblata, tum etiam quare fecit eis gratiam accedendi ad molendinum quo vellent et erigendi molendinum olei, ut prefertur ${ }^{59}$.

67. Fra Salvador de Luna (...) Vidit quod Poncius Laurencii, habitator loci de Gandesa, comande Miraveti, pro eo quia habuit rem agere cum quadam virgine servitrice sua, fuit captus et in carceribus detentus tamdiu et quousque realiter habuit dare moderno Castellano, composicione verbali interveniente, trescentos florenos auri Aragonie, hanc autem composicionem et pecunie solutionem credit injuste fuisse factam et extortam pro eo quia dicta puella non coacte sed voluntarie fuit deflorata, ut dicebatuf ${ }^{60}$.

\section{Capítol 13. Del regiment $i$ govern del castell de Miravet $i$ altres} fortaleses hospitaleres a mans dels fills del Castellà Roiç de Moros, en especial durant l'interregne successori de la Corona d'Aragó.

1. Fra Dalmau Dezcoll. Et dixo que es verdat que el Castiello de Miravet siempre, en tiempo d'esti Castellán, fue en poder del dito testimonio, qui de aquel era regidor por el dito Castellán. Empero que, muerto el Rey Don Martín, el dito Castellán mandó al dito testimonio que decendiesse del dito Castiello e que stiguesse en la villa de Miravet o en Gandesa, do más quisiesse, et regiesse la dita baylía como d’antes. Et aquellas oras el dito Castellán puso el dito Castiello en poder de Pero Royz, su fillo, et de Pero de Godenys, lego, procurador del dito Castellán. Es verdat que en el dito castiello finquavan tres frayres del dito orden, uno presbítero et dos sergantes, de los quales la uno era rebostero. Empero quel regimiento del castiello staba en mano de los sobreditos Pero Royz et Pero de Godenys. Et dixo que todoesto sabia porque en todo entrevino et lo vido.

2. Fra Miquel Calvo. Et dixo que es verdat que en cierto tiempo depués quel Regno d'Aragon vagava tenia las claves e guarda del dito castiello Pero Royz de Moros, fillo del dito Castellán, e En Pero de Godenchs, procurador del dito senyor, e, en absencia dellos, algunas vegadas, el bayle de Corbera e de Rasquera. Et siempre, en el dito tiempo, havia en el dito Castiello tres frayres capellanes e dos frayres sargantes, los quales el dito Pero Royz et los sobreditos tractaron muyt graciosament. Et sábelo esto porquey era ell, testimonio, present $\mathrm{e}$ ansí lo vio. Interrogado si sabia quel suegro de Gil Royz teniesse los castillos de Miravet et de Azcon. Et dixo que es verdat que lo vio star en el Castielo de Miravet, empero que no se curava sino de pregar Dios e comer e dormir. Et que el castiello de Azcon no sabe que jamás lo tuviesse. Et sabia que era apoderado vassallo del orden del lugar de Bordon, de la baylia de Castellot.

${ }^{59}$ El molí d'oli, l'erecció del qual concedeix el Castellà Roiç de Moros als de Batea és l'anomenat "Molí de la Vila", situat al carrer del Molí. Era un molí de sang amb les conduccions i dipòsits per a l'oli excavats a la roca viva. En queden les restes dins un pati tancat, propietat de Maria Carme Llop i Maijó, que té l'entrada pel carrer del Pantà. Cfr. Josep ALANYÀ I RoIG, Batea i el seu terme municipal, II, pp. 191, 375, 427-428. Josep AlANYÀ I ROIG-Arxiu AltÉS I AguILó, Els molins d'oli, a "La Vila Closa", I, pp. 77 i 87.

${ }^{60} \mathrm{ACA}$, Cancelleria, Processos en volum, lligam 47, plec A, fols. 157 v.-173 r. 
3. Fra Joan Emperador. Et dixo que li acuerda que un tiempo hi stuvo Pero Royz e el bayle de Rasquera e de Batea, mas quien đellos tenia las claves que no lo sabe et que en aquel tiempo el testimonio et los otros frayres que eran en el dito castiello eran bien tractados por los sobreditos, e que Fr. Dalmau Dezcoll, regidor del dito castiello, estava en la villa de Miravet et comia et bevia de lo del dito castiello. Et no sabe si por su voluntat o por ordinación del Castellán estava en la villa.

24. Blai de Lihori. Et dixo que li acuerda que en cierto tiempo, durando la vacación del Regno, Fr. Dalmau Dezcoll, qui por el dito senyor solia tener e regir el Castiello de Miravet, fue gitado fuera del dito Castiello. Et el regimiento del dito Castiello finquó en poder de hombres legos et que no sabia quales de los ditos fillos estava en el dito Castiello.

25. Ramon Jover. En tiempo de vacación del Regno, Fr. Dalmau Dezcoll fue gitado fora el dito castiello de Miravet et regíalo la hora Pero de Godenchs e Nalbert Esteve e otros legos ${ }^{61}$.

30. Fray Antonio Sánchez. Dixo que del Castiello de Azcon es cierto que, durando la dita vacación del Regno, en el mes de abril del anyo XIP ${ }^{62}$ cerqua passado, segunt consta por carta pública, por mandamiento del dito senyor Castellán, él, testimonio, rendió el dito Castiello de Azcon a Pero Royz de Moros, fillo del dito senyor, e el dito testimonio fizieron avallar de staga en la villa et el castiello e la senyoria se tuvo a mano del dito Pero Royz entro tanto que Rey huvo en Aragón. Et aprés, el dito Castiello fue rendido a ell, testimonio.

31. Pere Figuera. Dixo que li acuerda quen el tiempo que vagava el Regno, cierta terminada, no sabe quanta, vido Fr. Anthon, regidor de Azcon, star en la villa en las casas de Pero Roiz, et Pero Roiz dezian muytos que regia el dito castiello e allí lo vidia el testimonio $\operatorname{star}^{63}$.

33. Fra Miquel de Penya. Et dixo que ha oydo dezir a muytos, assin del dito orden como otros, que vacando el Regno, los regidores frayres, yes a saber Fray Dalmau Dezcoll e Fray Anthonio Servant, de los castiellos de Miravet e dAzon, fueron gitados de los ditos castiellos, romanieron en poder de Pero Roiz, fillo del dito senyor Castellán. Et el testimonio, en aquel tiempo, passando su ida enta Cort de Roma a Sant Matheu e Paníscola, puyó al dito Castiello de Miravet por dos caminos endo no lo lexaron entrar, antes li dixieron que havian mandamiento del dito senyor que noyde aculiessen frayre ninguno si no aduzia letra suya, excepto su fillo Mossén Johan, et que los ditos regidores fuessen itados por mandamiento del Castellán, tal yes pública fama.

\section{de l'Orde}

Capítol 15. Dels acensaments i arrendaments, en frau o no, d'heretats

1. Fra Dalmau Dezcoll. Sabe quel dito senyor Castellán havia asensado a un moro de Miravet, súbdito, un troz de tierra clamado la Cenia dAblora con oliveras a la sisena, no en

\footnotetext{
${ }^{61} \mathrm{ACA}$, Cancelleria, Processos en volum, lligall 47, plec A, fols. 57 v. $-60 \mathrm{r}$.

${ }^{62}$ Any 1412. La declaració testifical es féu l'any 1413.

${ }^{63} \mathrm{ACA}$, Cancelleria, Processos en volum, lligall 47, plec A, fols. 73 v.-75 v.
} 
la manera que es acostumbrado dar, que encara que den a tiempo las tierras, nunqua dan las oliveras, antes romanen a la casa e castiello de Miravet et él diólo a perpetuo con las oliveras que son en número de XXV a XXX oliveras. Et mas dixo que por muert de Fray Berthomeu Prades, frayre sargant del dito orden, que murió enforcado en Gandesa, devinieron de su despulla casas, vinyas e otras heredades e bienes mobles al dito oden, las quales casas, vinyas e heredades el dito senyor Castellán dio a senso perpetuo de X sols. a Johan Navarro, cambrero suyo.

Capítol 18. Del lliurament pel Castellà de les claus del tresor, pergamins, privilegis $i$ escritures públiques de l'Orde de l'Hospital als seus fills $o$ a altres persones laiques.

1. Fra Dalmau Dezcoll. Et dixo el testimonio que no ha visto quel Castellán haya lexadas las claves de los trasoros e privillegios a legos sino en mano del dito testimonio o del mismo Castellán e por otro tiempo en mano del dito Pero de Godenys, lego, procurador suyo.

2. Fra Miquel Calvo. Et dixo que nunqua vio que los fillos del dito Castellán tuviessen las claves del dito trasoro o algunas otras personas legas. Es verdat empero que algunas vegadas Pero Godenchs, procurador del dito Castellán, las tenia, pero havia mandamiento del dito Castellán de no entrar dentro el tresoro sin el regidor o otro frayre del dito Castiello, et esto sabia porque assin lo havia visto.

24. Blai de Lihori. Et dixo que sabe bien que en tiempos passados, antes que esti fuesse Castellán, el trasoro de Miravet era muyto riquo. Et ha oydo dezir a muytos... que agora es muyto desrobado, empero el testimonio no sabe por quien ni quales cosas son las cosas robadas. Et lo queyde sabe es por tanto que muytas vegadas en aquellos tiempos el testimonio entrava en el dito trasoro.

30. Fray Antonio Sánchez. Dixo quel dito Mossén Johan Royz de Moros tenia una spasa grant de dos manos, la qual, segunt se dizia en casa del dito senyor, era stada sacada del dito trasoro (del Castiello de Miravet).

33. Fra Miquel de Penya. Et quanto toca a los trasoros, dixo que vio las claves del trasoro de Miravet en manos de Anthon Dusay, qui era la hora procurador del dito senyor, e en otro tiempo las vio en mano de Pero de Godenchs, qui fue aprés procurador del dito senyor, e en manos d'otros legos, los nombres de los quales no li acuerdan.

Capítol 19. Si els castells de l'Orde, especialment el de Miravet, han estat despullats i privats de forniments, armes, roba i altres béns pel Castellà, pels seus fills o per altres persones laiques sabent-ho o consentint-ho el Castellà.

61. Fra Gundisalvo de Funes. Dicit quod modico tempore ante mortem Fratris Martini de Lihori, immediati preceptoris moderni castellani, vivente adhuc magistro Rodi, ipse testis fuit in Castro de Miravet et intravit domum Thesauri dicti Castri et tunch vidit munitam dictam domum quamplurimis armis, balistis, artilleriis, raubislectorum et mensarum ac libris et jocalibus preciosis, videlicet vanovis, linteaminibus, mapis delicatis, pannis de paramentis 
parietis et, ut postea audivit a Thesaurario Rodi et Nicolino de Lipo quod omnia predicta in dicta domo reperta posuerunt et dimisserunt in posse Castellani moderni post mortem predecessoris sui et credit quod pro nunch non sunt ibidem omnia, ymo deficiunt multa, nam, ut audivit ab ore proprio diti Castellani moderni, idem Castellanus dedit patri Comitis Urgelli moderni LXXX vel XC volumina librorum et tunch ipse Castellanus a dicto Comite in pignore recepit unam campanetam auri et unum anulum cum I pulcro balassio vel diamante, quos jam restituit dicto comiti prout idem Castellanus sibi dixit, sed qui et quales ac cuius valoris dicti libri erant ignorat $^{64}$.

62. Fray Pascasio Martín. Super XIX ${ }^{0}$ capitulo et eius partibus dicit quod vidit tempore predecessoris Castellani moderni Tesaurum Miraveti munitum multis armis diversorum generum, multis raubis preciosis curtinarum, pannorum, parietum tapetorum, catiffarum, linteaminum, vanovarum, matalaciorum, coxinorum de vellueto et serico, maparum longiarum de Flandres et aliarum multarum rerum; hodiernis autem temporibus vidit ipsum castrum quasi

${ }^{64} \mathrm{ACA}$, Cancelleria, Processos en volum, lligall 47, plec A, fols. 122 v.- 130 v. La declaració de Fra Gundisalvo de Funes és força desfavorable a la gestió de Roiç de Moros com a Castellà d'Amposta i recalca que només aquest, en mans del qual l'Orde va posar tots els béns de la Castellania, era responsable de l'empobriment del valor de les rendes de la Castellania així com de la forta depauperació en armes, roba de tota mena, joiells litúrgics i altres peces d'orfebreria, tapissos de paret, llenços delicats i llibres de la biblioteca del castell de Miravet. Faltant-ne l'inventari, no sabem si en la declaració Funes exagera la quantitat pel que fa al nombre de llibres que hi hauria al castell de Miravet, que serien molts atès que el Castellà havia lliurat a mans del comte d'Urgell, Pere el Savi, pare de Jaume el Dissortat, 80 o 90 volums (això ja és una gran quantitat de llibres aleshores) $i$ cal pensar que no li deixaria tots els existents a la biblioteca de la fortalesa. Així mateix costa de creure que aquesta gran quantitat de llibres, que havien de ser de molt de valor perquè tinguessin tant d'interès per al comte d'Urgell, li fos cedida tota alhora per Roiç de Moros amb la finalitat de fer-ne còpies, puix que la tasca de copiar era molt entretinguda i lenta. I, si és veritat el que declaren Funes i Pascasio Martín, resulta força sospitós que la garantia o penyora per la cessió dels llibres -una campaneta d'or i un anell, també d'or, amb un diamant encastat- fos retornada al comte d'Urgell i els llibres del castell de Miravet no fossin retornats per aquest a la biblioteca miravetana.

És coneguda de tots la dèria del comte Pere a manifestar la seva cultura i el seu poder mitjançant la formació d'una biblioteca important (Anton Maria ESPADALER, Un cançoner a la cort dels comtes d'Urgell, pp. 7-19; Eloi CASTELLÓ I GASSOL, L'edició del Cançoner dels comtes d'Urgell per Gabriel Llabrés, pp. 21 i ss., a Cançoner dels Comtes d'Urgell. Cal admetre amb fonament que aquest es va valer de l'amistat amb Roic de Moros per incorporar a la biblioteca del casal d'Urgell els volums prestats pel Castellà d'Ámposta. En no constar llur devolució al castell, cal creure que els llibres formaven part dels seixanta cossos de llibres manuscrits que, segons Monfar, el rei Ferran d'Antequera va endur-se després del setge de Balaguer (Diego de MONFAR, Historia de los Condes de Urgel, 1858).

La falta d'inventaris ens impedeix identificar qualsevol llibre. Sabem per la declaració de Fra Pascasio Martín que entre els llibres cedits hi havia la "Secunda pars Augustini De Civitate Dei" i que, anteriorment, en presència del mateix Castellà i a desgrat d'aquest segons declaració del prior de la Seu de Tortosa, Joan Siurana, el rei Martí l'Humà, de pas per Miravet, havia rebut 13 llibres, els títols dels quals ignorem, que formaven part de la biblioteca del castell (Plec A, fols. 130 v. -146 r.). Pensem amb fonament que els llibres anaren a parar a la Biblioteca d'Alfons el Magnànim i que eren inclosos en l'inventari existent en el volum 944 del Reial Patrimoni de l'ACA, avui perdut, publicat per GONZÁLEZ HURTEBISE a l' "Anuari de l'Institut d'Estudis Catalans" (1907), pp. 148 i ss. Cf. també Ramon d'Alós, Documenti per la Storia della Biblioteca d'Alfonso il Magnanimo, a "Miscellanea Francesco Ehrle, Studi e Testi", 41, vol. V, Roma, 1924, pp. 390-422. (Agraeixo aquesta dada al Sr. Jaume Riera). 
omnibus spoliatum, ubi autem sunt dicta bona et per quos fuerunt inde recepta et an sciente dicto Castellano dixit se nescire.

Est verum quod audivit ab ore Comitis Urgelensis, patris Comitis moderni, quod Castellanus dederat XC libros, quos idem Castellanus vel alius de sui mandato extraxit de dicto Tesauro Miraveti et tradidit Petro Dezmir, secretario dicti Comitis per eum ibidem destinato, et per dictum secretarium ipsi Comiti tradendos. Nomina vero dictorum librorum et eorum valorem ignorat ipse testis, excepto uno, quem vidit in presentia dicti Comitis, vocato Secunda pars Augustini De Civitate Dei; dixit ulterius quod audivit ab ore moderni Castellani quod Rex Martinus, dum fecit transitum per ipsum Castrum de Miravet, recepit de dicto Thesauro XIII volumina librorum, presente ipso Castellano, quorum nomina et valorem et an dictus Castellanus dederit ipsi Regi ignorat.

64. Fra Miquel de Penya, "profesor ordinis" (...) Dixit quod libros tradidit ipse testis Petro Dezmir, destinato per Comitem Urgelli quondam Castellano moderno et quod tradiderit omnes mandato expresso dicti Castellani idem Petro tradendos per eum dicto Comiti Urgelli. Et quod tunch recepit in pignore idem testis unam campanetam auri ponderis XXV unciarum et unum diamantem impressum in uno anulo auri ponderis trium quartorum, dempto pondere unius diamantis, prout hec clarius et latius continentur instrumento manu publica super hoc confecto, ubi omnes dicti libri designantur ${ }^{65}$. Dictos anulum et campanetam tradidit Johanni Navarro, cubiculario Castellani ac ratione per ipsum Castellanum ad eum destinato; quid autem factum sit de dictis anulo et campaneta dixit se ignorare ${ }^{66}$.

65. Joan Siurana. Dixit quod vidit tempore Fratris Johannis Ferdinandi de Heredia et Fratris Martini de Lihori, qui fuerunt Castellani Emposte, dictum Thesaurum Miraveti bene munitum et fulcitum armis, raubis lecti et parietum diversis et plurimis; qualiter stat de presenti et an de tempore istius Castellani fuerit, dicto Castellano sciente vel ignorante, aliquid inde receptum, transportatum seu alienatum ignorat, excepto quod audivit a pluribus quod de tempore istius Castellani per Regem Martinum in Castro de Miravet existentem, in dictum Thesaurum intrantem, fuerunt recepti, ut creditur malegratus Castellani, aliqui libri, quorum nomina ac materiam et valorem ignorat ${ }^{67}$; et audivit etiam, ut supra, quod dictus Castellanus acomodavit certos libros dicti Thesauri, quorum nomina et valorem ignorat, Comiti Urgelli, patri Comitis moderni, ac quod recepit ab eo in pignore quandam campanetam auri quam sibi restituit, nescit tamen si recuperavit libros ${ }^{68}$.

${ }^{65}$ Es tracta de l'inventari fet per mà d'escrivà públic, on constaven tots els llibres lliurats a Pere el Savi, comte d'Urgell, amb indicació dels autors i títols.

${ }^{66} \mathrm{ACA}$, Cancelleria, Processos en volum, lligall 47, plec A, fols. 150 v.-152 r.

${ }^{67}$ No sabem quins llibres eren els tretze que s'endugué del castell de Miravet el rei Martí i no sabem què se n'ha fet, però alguns d'aquests llibres podrien haver estat inclosos en l'inventari dels "libres los quals eren del Rei En Martí... los quals son pervenguts a mà o senyoria de la Reyna Margarita, muller sua, a la qual per certs títols pertanyen", que és el registre 2326 de la Cancelleria Reial de l'Arxiu Reial de Barcelona .

${ }^{68} \mathrm{ACA}$, Cancelleria, Processos en volum, lligall 47, plec A, fols. 152 r.- 157 v. 
67. Frater Salvator de Luna, comendator de Nonasp et de Alcoled ${ }^{69}$ (...) Scit ideo quia fuit presens quod, tempore quo Castellanus modernus recepit possessionem Castellanie de Miraveto, fuerunt inventariata omnia bona existentia et reperta intra castrum et thesaurum et capellam de Miraveto et inventarium recomissum Fratri Dalmatio Dezcoll.

(...) Dixit quod est verum quod Comes Urgeli quondam misit ad Castellanum Amposte modernum, qui tunch erat in Castro Miraveti, Petrum Dezmir, secretarium suum, qui ex parte ipsius Comitis eidem Castellano dixit quatenus libros existentes intra Thesaurum Miraveti vellet ei hostendere, cuius rogaminibus obtemperans Castellanus, libros existentes intra dictum Thesaurum dicto Petro hostendere fecit et ostensos eidem particulariter in quodam memoriali descripsit et descriptos dicto Comiti Rotulum, ubi erant descripti, reportavit prout hec omnia idem testis, presencialiter existens, vidit et audivit et, notitia dictorum librorum ex tenore dicti Rotuli per dictum Comitem percepta, prout audivit a pluribus, et cetera, idem Comes dictum Petrum Dezmir ad eundem Castellanum iterum missit rogans eundem Castellanum ut libros descriptos in dicto Rotulo Petro jamdicto vellet accomodare ut posset ipsos transcribire et dicto Petro dare per ipsum eidem Comiti dandos. Quiquidem Castellanus, volens in hac parte dicto Comiti complacere, libros in dicto Rotulo descriptos cum eodem Petro dicto Comiti misit, receptis a dicto Petro, nomine dicti Comitis, in pignore, quadam campanellam (sic) auri et unum anulum aureum in quo erat impresum unum diamant, prout hec a pluribuset cetera, cuius ponderis, cuius valoris essent ignorat; an dicti libri sint reportati ad dictum Thesaurum vel restituti dicto Castellano, dicit quod non. Et scit ideo quia audivit a dicto Castellano quod nondum sunt sibi restituti et talis est fama publica inter fratres et alios existentes in dicto Castro. Etiam idem testis pluries ibi intraverit post dictam traditionem, ut dicitur, factam, non tamen eos vidit in dicto Thesauro, dicta autem pignora tradita Castellano, prout audivitet cetera, fuerunt restituta jam dicto Comiti. Dicti autem libri fuerunt traditi dicto Petro Dezmir per fratrem Dalmau Dezcoll, regentem Castrum et bajuliam Miraveti, mandato dicti Castellani prout audivi, et cetera.

Capítols 20, 21 i 22. Del carregament de deutes fet pel Castellà sobre els vassalls de la Castellania i de les execucions $i$ danys patits per aquests com a conseqüència dels negocis $i$ interessos personals del Castellà.

1. Fra Dalmau Dezcoll. Et en verdat sta que dito senyor Castellán, quando fue con ciertos hombres d'armas a nuestro senyor lo Papa quando sallió del Palacio dAvinyon, manlevó LX mil sols. barchinoneses et por estos se obligaron por el dito Castellán los vassallos de todos los lugares de la baylia de Miravet, faziendo, por aquellos, IIIM sols. de censal cada anyo. Et el dito Castellán assignó por quitar los ditos LX ${ }^{M}$ sols. a los ditos vassallos todas las rendas suyas de los ditos lugares. Et que de aquellos los ditos vassallos quitaron el dito deudo tanto que solament oy ne restan a quitar MD florins d'Aragón segons el dito testimonio ha oydo dezir a muytos de los ditos lugares... Es verdat que ha oydo dezir que muytas vegadas los ditos

\footnotetext{
${ }^{69}$ Aquesta és la segona declaració que va fer en el procés Fra Salvador de Luna, en diferents dia i lloc de la primera. La primera (Plec A, fols. 97r.-106 v.) és la que porta assignat el número
} 47. 
vassallos requirian lo procurador del dito senyor Castellán que los pagasse; empero si los pagava o non, no lo sabe.

24. Blai de Lihori. A lo que es contenido en el derrer capítol de los deudos dixo que las cosas contenidas en aquel son veras e sábelo por queyda cabido e hi paga su part por lo que tiene en Gandesa. Et las ditas cosas dixo que sabia por tanto que XXII anyos era stado bayle de Gandesa de tiempos de Fr. Johan Fernández de Heredia quondam maestro de Rodas et depués de Fr. Martin de Lihori quondam Castellán.

27. Lorenç Aguiló, veí de Corbera (...) Et dixo que li acuerda que ell, testimonio, cerqua ha de un anyo que passava Mossén Ramon de Perellós con $\mathrm{CCCC}^{\mathrm{s}}$ hombres d'armas que yvan a Castellón de Borriana, et el dito senyorCastellán, contra voluntat de los del dito lugar de Corbera, con el regidor de Miravet mandólos acullir en la dita universidat. Recurriendo al dito senyor por suplicar lo que esta gent no entrasse en el dito lugar. El qual dito senyor, con conminación, los mandó que los aculliessen, et ellos, forçados, recullieron los, de que staron a muyt grant periglo e prendieron los de las pallas e civadas e otros biures, de los quales no podieron haver paga sino segunt a los ditos darmas plazia, como los del dito lugar no fuessen bastantes a constrenyer $\operatorname{los}^{70}$.

29. Bernat Miquel, veí de Corbera (...) Et dixo que un anyo ha passado o cerqua, que cierta gent d'armas, cerqua de CCXXXX hombres d'armas del Compte d'Urgell que hivan a Castellón de Buriana, devian passar por aquella terra. Et el senyor Castellán scrivió a los del dito lugar que aculliessen los ditos hombres d'armas. Et la dita universidat dixieron que no lo querian, dubdando que, quando fuessen dentro, de sus mulleres e bienes no se pleniessen, que podrian mas que los de la villa. Et por esto la dita universidat envió a él, testimonio, e a Periquo Mateu, jurado de la dita universidat, al dito senyor que era en Azcon, que li plaziesse que los ditos hombres d'armas no entrassen en el dito lugar, car por cierto ellos no los querian acullir. Et a la conclusion, el dito senyor les mandó que los reculliessen et que no se pasiessen en otro, et por esto envió a Corbera el regidor de Miravet, el qual tomó las claves del dito lugar et fízolos entrar. Et aprés tomaron civadas et biures et pagavan como se querian, de la palla non $\operatorname{pagavan}^{71}$.

37. Duren Albert. Et dixo que sabe que las universidades de la comanda de Azcon son obligadas por el dito senyor Castellán en XX mil sueldos, por los quales han sustenidos danyos de expensas e missiones... El dito senyor, mediant su procurador Anthon Dusay, ha feyto obligar a él, testimonio, e ciertos singulares de Vilalba, que son En Jacme Cirera, Maciá Guarch, Berenguer Urgellés, Boraz Peroarnau, Bernat Criviller, Domingo Cabrer quondam en

${ }^{70}$ ACA, Cancelleria, Processos en volum, Lligall 47, plec A, fols. 62 v.-64 r. Ramon de Perellós, partidari del comte Jaume d'Urgell, baixava cap a la Plana de Borriana amb gascons i gent del comtat, armats, a ajudar els urgellistes del regne de València i unir-se a les tropes que eixien de València a les ordres del seu governador, Guillem Arnau de Bellera, en defensa dels interessos del comte d'Urgell, única persona a qui obeien, i contra la voluntat i parer dels parlamentaris reunits a Tortosa, davant els quals Perellós féu una encesa defensa dels drets a la Corona de Jaume d'Urgell. La declaració del testimoni de Corbera, Llorenç Aguiló, posa en evidència la col-laboració de Roiç de Moros als moviments armats del comte d'Urgell i dels seus partidaris. Vegi's M Ma Mercè CosTA, Perellós, Ramon de, a Gran Enciclopèdia Catalana, 11, pp. 472-473.

${ }^{71} \mathrm{ACA}$, Cancelleria, Processos en volum, lligall 47, plec A, fols. 66 r. -67 v. 
setecientos florins de Aragon a dos judios de Falcet ques claman Jucef de Tolosa e David Mercadell, de los quales DCC florins han pagat interés a raó de XV florins per centenar de florins cascun anyo et començaron a correr al dit interés a VI de juny del anyo MCCCC $\mathrm{V}^{\mathrm{o}}$, los quales dineros, axi principal como interesses, nunqua han podido haver los sobreditos obligados del dito senyor ni de su procurador yatsia muytas vegadas los han demandado $z^{2}$.

38. Bernat Criviller. Et dixo que acuerdali que el testimonio con otros seys singulares de la dita baylia se obligaron por el dito senyor a ciertos judios de Falcet en DCC ${ }^{\text {s }}$ florins, los quales, ni el interés de aquellos, nunqua del dito senyor han podido cobrar segunt mas largament por una cédula delant nosotros dada se aparece $e^{3}$.

47. Fra Salvador de Luna. Et dixo que sabia quel dito senyor, algunas vegadas por sus necesidades, assin como quando fue a nuestro senyor el Papa a Marsella, como quando fue a Perpinyan al concilio, como quando vino en Aragon contra Don Anthonio de Luna e en otras guisas, havia manllevadas ciertas quantias, no li acuerda la suma, en las quales li han feytas fermanças algunas universidades de sus cambras ${ }^{4}$.

Capítol 24. Dels diners cobrats pel Castellà en ocasió de deutes propis contrets o de despeses personals.

24. Blai de Lihori. Dixo que li acuerda que li parece que quando el dito senyor Castellán entró en la Castellania, la baylia de Miravet li dio mil florins o cerqua. Et depués, entre dos vegadas, lin dan dados otros mil florins.

58. Fr. Martin de Lodosa, "prior curado de la eglesia parrochial de Mallén". Dixo que hoyó dezir a Eximén Pérez d'Ayerbe, scudero de Mallén, que él, de la spuella de Fr. Martin de Lihori quondam, Castellán d'Amposta, havia comprados ciertos tapetes e drapos de paret e otras cosas e un libro clamado Maestre Arnau de Villanueva en suma de CCC florins, las quales ropas e libro el dito Ximén Pérez lexó al dito Castellán por aquel precio mismo, e el dito senyor en pago d'esto asignó la quantitat desús obligada por el padre del testimonio ${ }^{75}$.

\section{Capítols 25 i 26. De comerç carnal del Castellà Roiç de Moros amb} concubines; quines, quantes, des de quant i on les tenia.

1. Fra Dalmau Dezcoll. Si'l dito Castellán ha tenidas concubinas, el testimonio no sabe de cierta sciencia, mas que ha oydo dezir a muytos quel dito Castellán, antes que fuesse Castellán, stando comendador de Castellot, tenia por concubina a sus proprias expensas la madre de Mossén Johan Royz, Gil Royz, Pero Royz e Sor Marquesa, fillos della e del dito Castellán.

\footnotetext{
${ }^{72}$ ACA, Cancelleria, Processos en volum, lligall 47, plec A, fols. 88 v.-90 v.

${ }^{73} \mathrm{ACA}$, Cancelleria, Processos en volum, lligall 47, plec A, fols. 90 v.-91 v.

${ }^{74} \mathrm{ACA}$, Cancelleria, Processos en volum, lligall 47, plec A, fols. 97 r.-106 v.

${ }^{75}$ ACA, Cancelleria, Processos en volum, lligall 47, plec A, fols. 120 r.- 121 r.
} 
Et dixo que noy sabe res cómo havia nombre la dita concubina e si quando la tomó en concubina era virgen o casada o vidua o religiosa, cristiana o de otra ley.

Interrogado si sabia quel dito Castellán, quando fue feyto Castellán e aprés que fue feyto Castellán, tenia o ha tenido concubina o concubinas públicament o scondida et de qué condición. Et dixo que en el tiempo que fue feyto Castellán tenia la madre de los sobreditos fillos. Et aprés uniendo aquella los ditos fillos mandaron a ella, madre lur, que no tornasse con él pus a conversar. Et esto havia oydo dezir a muytos. Et la ora, el dito Castellán prison otra clamada Johanna, la qual tuvo en Miravet e en Corbera a sus proprias expensas públicament, et quando l'havia menester el dito Castellán embiava por ella et dizian que era de Çaragoça. Et esto sabia por tanto que assin lo havia visto. Et dixo que no sabe si la dita Johanna era virgen, casada o religiosa, e si la havia hovido por fuerça, mas que bien conosció su padre e madre cristianos, e quel dito padre murió en Corbera et la madre, quando la dita Johanna fue muerta, que murió en Miravet cerqua ha dos anyos, sende tornó a Çaragoça.

Dixo que non sabe que los frayres o comendadores del dito orden supiessen quel dito Castellán tuviesse la primera concubina. Quanto a la segunda concubina, sabe bien que todos los frayres de la casa de Miravet e vassallos de Miravet et de Corbera, públicament e notoria, havian e reputavan la dita Johanna esser concubina del dito Castellán e vivir a proprias expensas de aquel et tal era pública voz e fama entre ellos. Et esto sabia por tanto como en el dito tiempo stava e era regidor de la baylia de Miravet e veya quando los ministros de dito Castiello li administravan sus alimentos; de los comendadores e frayres de la dita Religión, si lo sabian o no, dixo que no lo sabe, mas que bien piensa que lo han visto e oydo dezir. Depués muert de la dita Johanna non da tenida nin tiene oy ninguna quel testimonio sepa (...)

Et de la dita Johanna creye que ha havidos el Castellán IIIP o $\mathrm{V}^{\circ}$ fillos. Es verdat que solament viven dos, es a saber, Violantet Rodrigo, los quales fueron batiados en Corbera. Et que la dita Violant es de XII anyos o cerqua, et Rodrigo es de edat de quatro anyos o cerqua, et lo tienen por padre et ell por sus fillos.

2. Fra Miquel Calvo. Et dixo que depués quel testimonio fue venido en el dito castiello, el testimonio enterró una fembra en el fossar del dito castiello, la qual, segunt se dizia e era fama pública en Corbera e en el Castiello de Miravet, era manceba del dito Castellán.

24. Blai de Lihori. Et dixo que el testimonio havia conoscido al dito Castellán dos mancebas, de las quales la primera se clamava, a su parecer, Maria Alfonso, de la qual huvo antes que fuesse Castellán, Mossen Johan Roiz, Gil Roiz et Pero Roiz, Dona Marquesa, monga de Trasovares, los quales hoy viven. Et la otra, la qual tuvo depués que fue feyto Castellán, se clamava Johanna. Et desta huvo tres o quatro fillos, de los quales solament viven hoy un fillo e una filla. Et dixo que ell, testimonio, a instancia del dito senyor Castellán e de la dita Johanna, fue compadre lur baptizando el dito fillo. Et dixo que entramas mancebas... son muertas. 
Capítol 27. De la cooperació i ajut armat de Roiç de Moros i dels seus al comte Anton de Luna contra el governador d'Aragó i els Urrea.

1. Fra Dalmau Dezcoll. Et dixo que noy sabe res de certa scientia ni encara de oyda de la partida quel Castellán fizo contra Gil de Lihori, olim governador, e de los danyos que siguieron a los lugares ${ }^{76}$.

33. Fra Miquel de Penya. Et dixo que sabe e ha visto al senyor Castellán con sus fillos seyer ligado e en ajuda de los de Gurrea contra Don Anthon de Luna. Et lo ha visto en ajuda de Don Anthon de Luna contra Don Pedro de Gurrea. Et con Don Pedro de Gurrea contra Don Anthon de Luna. Et en el tiempo quel Regno vagava, con el Conte dUrgel et Don Anthon, e toda su partida, contra Don Pedro de Urrea et Mossén Gil Roiz $z^{7}$, la hora governador, e su fillo, Mossén Johan Ferrández e toda su partida. Et esto sabe porque el dito testimonio muytas vegadas en el anyo es stado e ha acostumbrado de esser en casa del dito senyor e es stado su servidor por luengos tiempos ${ }^{78}$.

62. Fray Pascasio Martín. Et dixit se scire quod dictus Castellanus, una cum Anthonio de Luna, faciebat partem et dabat adjutorium Comiti Urgelli et vidit quod, ipso teste existente in Almunia, dictus Castellanus erat capitaneus generalis omnium gentium armorum dicti Comitis et partis sue. Et etiam Anthonius de Luna et gentes Castellani irruerunt contra gentes partis Gubernatoris et aliorum descriptorum in presenti articulo et duxerunt captos Raymundum de Mur, militem, bajulum generalem Aragonie, et Ludovicum Coscon, filium Bertrandi Coscon, et certas adzemilas Archiepiscopi Cesarauguste, quos et quas secum duxerunt captos ad locum de Almonezir ${ }^{79}$.

Capítol 28. Dels danys patits per la Castellania de part dels enemics de Roiç de Moros i per causa de les parcialitats del Castellà.

1. Fra Dalmau Dezcoll. Dixo que en la baylia de Miravet los enemigos del Castellán por desamistança del dito Castellán no han dados danyos en los lugares e hombres de la dita Castellania. Es verdat que havia oydo dezir que en los lugares quel Castellán ha en Aragón han dados danyos. Et esto havia oydo dezir a muytos, los nombres de los quales non le acuerdan. Et mas dixo que se acordava que tres moros de Miravet que eran ydos con un present quel dito Castellán embiava a la senyora d'Íxar fueron presos en el campo de Sant Per de Calanda por ciertos, los nombres de los quales no sabe, de la partida contraria del Castellán, los quales moros se rescataron segunt se dize cient florines o cerqua. Et esto sabia por relación de los ditos moros.

${ }^{76} \mathrm{El}$ declarant es refereix als llocs de la Castellania d'Amposta.

${ }^{77}$ Gil Ruiz de Lihori, governador d'Aragó.

${ }^{78} \mathrm{ACA}$, Cancelleria, Processos en volum, lligall 47, plec A, fols. 77 v.- 81 v.

${ }^{79} \mathrm{ACA}$, Cancelleria, Processos en volum, lligall 47, plec A, fols. $130 \mathrm{v} .-146 \mathrm{r}$. 
Capítols 30 i 31. Del cobrament de quantitats dineràries pel Castellà en ocasió de sentenciar parcialment, amb prevaricació, o d'administrar justícia.

9. Ferrig Çalmedina, moro de l'aljama e villa de Miravet. Dixo que es verdat que oyó dezir a Fomat Zamer e a Mossegui lo qual emprava al dito testimonio de XX florins, los quales dizia quel dito Castellán havia tennidos presos a él e al dito Fomat havian a dar al dito senyor Castellán gran quantia por algunos processos que los havia feytos, los quales el testimonio no sabe si eran justos o injustos porque no era el testimonio en Miravet quando los processos se fizieron. Empero hoyó dezir continuament a los de Miravet que gran tuerto los era feyto. Et de si mismo sabe que li fue feyto tuerto faziendoli pagar al dito Castellán cient florins porque fizo stanca o caplevó un moro pastador del dito castiello, el qual tenian preso en fierros e presones, la qual capleuta fizo en condición quel regidor del dito Castiello, Fr. Dalmau Dezcoll, teniesse el dito preso en guarda dentro'l castiello e li levasse los ferros. Et el dito regidor enviava el dito moro al forno en la villa e a cerquar spáragos e caracoles e a otras partes do li plazia, en tanto quel dito moro sende fue. Et la hora fizieron execución a él, dito testimonio, en los ditos cien florins ${ }^{80}$.

Capítol 33. Del títol i provisió en virtut dels quals Roiç de Moros era Castellà d'Amposta.

24. Blai de Lihori. Et sabe que por provisión de nostre senyor lo Papa qui hoy es, ell es Castellán. Et assin et non en otra manera lo ha oydo dezir al dito Castellán. Et ell, testimonio, ha visto la bulla de la dita provisión ${ }^{81}$.

Capítol 34. D'obtenir informació de quant havien de pagar o havien pagat de responsió a l'Orde de l'Hospital les cambres del Castellà d'Amposta.

67. Fra Salvador de Luna. Dicit quod vidit quod Frater Gauterius Grassi, prior ecclesie colocensis Rodi, ut locumtenens magistri, mediante publico instrumento in Capitulo Gandesie celebrato, in virtute sancte obediencie mandavit moderno Castellano quod contribueret pro cameris suis in responsione IIII mille florenis pro parte ipsum contingente. Et tunch idem Castellanus, dicens se non teneri, petiit sguardium fratrum, quod idem locumtenens sibi assignavit mandans eidem quod infra quatuor menses compareret aut responderet per se vel procuratorem suum in conventu Rodi responsurus, et cetera. Si infra dictum tempus, per se vel

${ }^{80} \mathrm{ACA}$, Cancelleria, Processos en volum, lligall 47, plec A, fols. 31 v.-32 v.

${ }^{81} \mathrm{ACA}$, Cancelleria, Processos en volum, lligall 47, plec A, fols. 51 v.-57 v. 
procuratorem suum, comparuit, ignorat. Scit tamen quod hac ratione dicti Berengarius Tarrag $8^{2}$ et Sanccius d'Espeio per modernum Castellanum fuerunt illuc missi.

(...) Vidit quod in assemblea celebrata tempore Magistri Johannis Ferdinandi de Heredia in Sancto Spiritu fuit ordinatum per proceres dicte assemblee quod tota Castellania simul cum cameris Castellani tenerentur facere de responsione annua Thesauro Rodi IIII mille florenos Aragonie ${ }^{83}$.

Capítol 35. Del compliment de Roiç de Moros amb els preceptes de l'Església, especialment els de la confessió i comunió almenys un cop a l'any, del rés de les hores de l'ofici diví i de l'observança de les cerimònies pròpies de l'Orde de l'Hospital.

1. Fra Dalmau Dezcoll. Et dixo que en las fiestas anyales, en las quales el dito Castellán s'es encerrado en el Castiello de Miravet, do el dito testimonio faze residencia, lo ha visto confessar o comulgar; qué fazia en las otras partes o lugares, dixo el testimonio que no lo sabia en quanto no conversava con él. Ítem si sabia cómo el dito Castellán dize sus horas, dixo que en quanto el testimonio ha conversado con el Castellán, que ha visto que muyt bien las dize. Ítem si sabia quel dito Castellán haya acostumbrado servar et guardar las cerimonias de su Religión et si las ha feytas servar a los otros de su Religión et dixo que sí en quanto el testimonio ha podido veyer e entender.

2. Fra Miquel Calvo. Et dixo que tanto quanto el testimonio ha estado en casa e servicio del dito Castellán, el dito Castellán en las fiestas anyales mandadas por su orden, que son Nadal, Paschua florida e Pentacosta, se ha confessado e recebido el sagrament de la Eucaristia. Et mandado despropriar et fer confessar e comengar a sus frayres. Et mas dixo que siempre la visto dezir bien sus paternostres e el oficio de muertos e otras oraciones ordinariament.

62. Fray Pascasio Martín. Dixit quod in festis solempnibus, in quibus secundum ordinem sunt adstricti, vidit eum (Castellanum) confiteri et recipere sacramentum Eucharistie et dictis temporibus et alias, dum conversabatur cum eo, vidit eum dicentem bene suas horas et diebus mercurinis comedere carnes, diebus venerinis comedere ova licet sit prohibitus. In vestibus autem et calceamentis ac forraturis ipse, prout omnes ceteri, quos vidit, deviant a cerimoniis et ordinatione Religionis; dicit ulterius quod non vidit ipsum sollicitum et diligentem in faciendo servari dictas cerimonias.

${ }^{82}$ Berenguer Tarragó, segons declaració de Fra Pascasio Martín, era rector d'Orta; segons la de Fra Salvador de Luna, era rector de Calaceit. Sancho d'Espeio era escuder del Castellà Roiç de Moros.

${ }^{83} \mathrm{ACA}$, Cancelleria, Processos en volum, lligall 47, plec A, fols. 157 v. -173 r. 
Capítols 36 i 38. De la negligència del Castellà a fer $i$ administrar justícia als seus vassalls, religiosos o laics, $i$ de la permissivitat a tenir concubines els frares hospitalers de la Castellania.

1. Fra Dalmau Dezcoll. Et dixo que bien creye quel dito Castellán sia stado negligent en corregir los comendadores, empero, sguardada la malicia del tiempo, que buenament no lo haya podido fazer antes y de ha dadas grandes passadas. Ítem interrogado el testimonio sil dito Castellán ha sostenido dentro de sus baylias religiosos de su orden tener concubinas. Et dixo quendi havia e el dito Castellán lo sabia e los dizia et reptava que non teniessen, empero que no les fizo tales constreytas porque las lexassen. Interrogado quales son aquellos qui las tenian et dixo quel mismo testimonio et fray Johan el repostero del dito Castiello et Fray Miguel de Miralles, conventual de allí, et Fray Domingo d Alforge, qui es hombre de LXXX anyos, e ella de semblant edat, que apenas se pueden ayudar e entramos stan fuera en una granga del dito castiello. Et otros nondi sabe en la baylia de Miravet. Et dixo que el testimonio, Fr. Johan et Fray Miguel a present no tienen las ditas concubinas, antes todos las han gitadas de si et de toda la tierra del orden ${ }^{84}$.

2. Fra Miquel Calvo. Verdat es que era fama que Fr. Dalmau Dezcoll, regidor del dito Castiello, ne tenia una (de concubina), endo huvo una filla, et Fr. Johan de Miralles e Fr. Johan Emperador, repostero, et Fr. Domingo đ Alforge, el qual es de edat LXXX anyos e está en una granga del dito castiello, en de tenian. Empero todas las han lexadas grant tiempo ha, e no se puede saber que sean en lugar algun del orden, excepto la que tenia Fr. Domingo, la qual encara tiene e es de hedat de LXXX anyos en grande veleza e sta en la dita grang $a^{85}$.

3. Fra Joan Emperador. Et dixo que de la concubina que él (Fra Joan Emperador), testimonio, tenia, sabe que non la huvo virgen; de las de los otros, dixo que no lo sabê.

62. Fray Pascasio Martín. Dixit quod audivit ab ore Castellani quod Frater Rogerius Durries, comendator d'Ambel, violenter rapuerat quandam puellam virginem sue comande et eam violaverat prout mater dicte puelle deponens querimoniam Castellano et petens de dicto Comendatore sibi justitiam ministrari, que, licet fuerit petita, nullatenus tamen facta per Castellanum, prout audivit ab eodem Castellano dicente et se excusante quod tempus non patiebatur quia erat disceptatio Regni. Idem etiam audivit a Fratre Enneco de Alfaro, comendatore de Ricla, dicit ulterius quod de toto tempore regiminis sui non vidit eum aliquem comendatorem nec fratres corrigentem nec scit si clamores venerunt coram eo de aliquo ali 87 .

\footnotetext{
${ }^{84} \mathrm{ACA}$, Cancelleria, Processos en volum, lligall 47, plec A, fols.7 v.-21 r.

${ }^{85} \mathrm{ACA}$, Cancelleria, Processos en volum, lligall 47, plec A, fols. 21 r.- 24 r.

${ }^{86} \mathrm{ACA}$, Cancelleria, Processos en volum, lligall 47, plec A, fols. 24 r.-26 v.

${ }^{87} \mathrm{ACA}$, Cancelleria, Processos en volum, lligall 47, plec A, fols. 130 v.-146 r.
} 
Capítol 37. Si el Castellà d'Amposta té llibre inventari dels béns, rendes, censos $i$ drets senyorials de les seves batllies.

30. Fray Antonio Sánchez. Et dixo que en cada castiello de Miravet et de Azcon, do el testimonio ha estado, sabe que ha libros de todas las rendas de las otras baylias e assin lo ha visto.

El plec A, còpia de les declaracions testificals del procés contra Roiç de Moros, es tanca protocolàriament amb la signatura i autorització del notari actuant, Francesc Gener, rector de Sant Mateu. S'hi indiquen el nombre de folis que el formen, el nom del notari que va intervenir en les deposicions dels testimonis, Niolau Balaguer, ja difunt quan es va fer la còpia, el lliurament de les declaracions al rector de Sant Mateu i la confecció de la còpia per ordre del papa Benet XIII, i el destinatari de la còpia testifical, Fra Gundisalvo de Funes, aleshores Castellà d'Amposta:

Ego Franciscus Januarii, presbiter, rector Ecclesie Sancti Mathei, diocesis dertusensis, publicus apostolica auctoritate et Camere Apostolice notarius, hanc copiam manu alterius scriptam et eius ac manu mea propria correcta continentem centum et quatuor folia ab originalibus testium depositionibus, quibus intervenerat discretus Nicholaus Balaguerii, publicus apostolica auctoritate et Thesaurarie dicte Camere notarius, nunch vita functus, que quidem supranominatorum (testium) depositiones michi postea ex ordinatione Domini nostri Pape tradite fuerunt, extrahi et fideliter copiari feci et cum originali bene et veridice comprobari ad opus Reverendi Domini Fratris Gundisalvi de Funes, nunch Castellani Emposte’. 


\section{FONTS I BIBLIOGRAFIA}

\section{FONTS INÈDITES}

Arxiu de la Corona d'Aragó (Barcelona)

1. Cancelleria Reial

a) Processos en volum.

Lligall 47. Procés inquisitorial contra Fra Pedro Roiç de Moros, Castellà đ̊ Amposta.

b) Registres de Cańcelleria.

Registres 310, 2289, 2326, 2328, 2333, 2383, 2400, 2407, 2408, 2459, 2563, 2568, 3237.

2. Ordes Militars. Sant Joan de Jerusalem.

a) Armari 9, vol. 2. IX Butlles papals de privilegis de l'Orde de l'Hospital de Sant Joan de Jerusalem. Any 1472.

b) Armari 9, vol. 3. Privilegia Ordinis Sancti Ioannis Hierosolimitani. Any 1563. Inclou butlles de confirmació de privilegis de l'Orde de l'Hospital dels papes Pius IV (1560), Sixt V (1586) i Gregori XIV (1591).

\section{BIBLIOGRAFIA}

AlanYà I RoIG (Josep), El terme municipal de Batea: Carta de poblament de la Vall Major, a "La Vila Closa", Patronat pro Batea, 1989, I, pp. 151-159.

_, Els molins d'oli, a "La Vila Closa", Patronat pro Batea, 1988, I, pp. 77, 87.

-, Batea i el seu terme municipal. El repoblament templer (s.XII-XIII), Institut d'Estudis Tarraconenses Ramon Berenguer IV, Diputació de Tarragona, Tarragona, 1994.

-, Llibre de la Mare de Déu del Portal, Patrona de Batea edició numerada, Batea, 2000.Alós (Ramon d'), Documenti per la Storia della Biblioteca d'Alfonso 
il Magnanimo, "Miscellanea Francesco Ehrle. Studi e Testi", 41, vol. V (Roma, 1924, pp.

390-422.

Alós (Ramon d'), Documenti per la Storia della Biblioteca d'Alfonso il Magnanimo, "Miscellanea Francesco Ehrle. Studi e Testi", 41, vol. V (Roma, 1924, pp. 390-422.

Álvarez Palenzuela (Vicente Ángel), El Cisma de Occidente, Ediciones Rialp, Madrid, 1982.

Bofarull (P.M. i F. de), Colección de documentos inéditos del Archivo general de la Corona de Aragón (CODOIN), Barcelona, 1849-1910. Vol. II.

BONNEAUd (Pierre), Le rôle politique des ordres militaires dans la Couronne d'Aragon pendant l'interrègne de 1410 à 1412 à travers les Anales de Zurita, a "Aragón en la edad media (XIV-XV)", I, pp.119-141.

CASTElló I Gassol (Eloi), L'edició del Cançoner dels comtes d'Urgell per Gabriel Llabrés, a Cançoner dels Comtes d'Urgell, p. 21 i ss. Lleida, 1999.

Costa ( ${ }^{\mathrm{a}}$ Mercè), Perellós, Ramon de, a Gran Enciclopèdia Catalana, 11, pp. $472-473$.

Delaville Le RoulX (J.), Les hospitaliers à Rhodes jusqu'à la mort de Philibert de Naillac (1310-1421), Paris, 1913.

ESPADALER (Anton Maria), Un cançoner a la cort dels comtes d'Urgell, a Cançoner dels Comtes d'Urgell, Lleida, 1999, pp. 7-19,

EuBEL (C.), Hierarchia catholica medii aevi, Munster, 1898-1901.

GARCÍA VILladA (Ricardo), Historia de la Iglesia en España, III-1 ${ }^{\circ}$, Biblioteca de Autores Cristianos, Madrid, 1980.

LlabRÉs (Gabriel), El Cançoner dels Comtes d'Urgell, Barcelona, 1906.

LLIBRE D'HORES, a cura de Germà Colon, Editorial Barcino, Barcelona, 1960. Aquest exemplar, guardat a la biblioteca de la Societat Castellonenca de Cultura de Castelló de la Plana, procedeix de Morella.

Milián BoIX (Manuel), Postrimerías del Cisma de Occidente: Francisco Rovira Escuder, secretario de Benedicto XIII, el Papa Luna, yagente confidencial de Alfonso $V$ el Magnánimo (1375-1450), a "Miscel-lània dedicada a la memòria de Mossèn Manuel Milián Boix", Amics de Morella i Comarca, Morella, 1991, pp. 21-52.

Soldevila (Ferran), Història de Catalunya, Editorial Alpha, Barcelona, $2^{\text {a }}$ edic., 1963.

WIECK (Roger S.), The Book of Hours in Medieval Art and Life, Sotheby's Publications, London, 1988.

ZuRITA (Jerónimo), Anales de la Corona de Aragón, Edició d’Ángel Canellas López, Saragossa, 1980, vol. 5. 


\section{APÈNDIX DOCUMENTAL}

Sentència del procés inquisitorial obert pel tribunal de Benet XIII contra Fra Pedro Roiç de Moros, Castellà d'Amposta.

ACA, Cancelleria, Processos en volum, 47. Plec 105 B/5B, fols. 1 r.-4 r. Còpia de 1417.

Es troba també en el Plec 136/5, fols. 43 r. -45 v.

In Dei nomine. Noverint universi quod hoc presens transumptum exemplar seu vidimus et publicum visuris et lecturis et audituris tam presentibus quam futuris. Nos Petrus de Jassá, Decretorum doctor, canonicus et operarius ecclesie ac officialis Cesarauguste, notum facimus per presentes Quod nos vidimus, tenuimus et palpavimus et diligenter de verbo ad verbum inspeximus quoddam publicum instrumentum sententie seu pronuntiationis late per Reverendissimos in Christo Patres ac Dominos, Dominos Johannem, tituli Sancti Laurentii in Damasco, Montisaragonum vulgariter nuncupatum, et Petrum Sancti Angeli, Cardinales Sancte Romane Ecclesie, contra dominum Fratrem Petrum de Moros, olim Castellanum Emposte, pergameneum scriptum et manu publici notarii signatum ac sigillis dictorum dominorum cardinalium in pendenti sigillatum, non vitiatum, non cancellatum nec in aliqua sui parte suspectum sed omni prorsus vitio et $[\ldots]$ carens, nobis pro tribunali $[\ldots]$ per $[\ldots]$ de Turribus, vicinum dicte Civitatis, procuratorem Reverendi domini Fratris Gondissalvi de Funes, Castellani Emposte, ordinis Hospitalis Sancti Johannis Jerosolimitani constitutum cum publico procurationis instrumento, confecto Cesarauguste XXVII die mensis Julii anno a nativitate Domini millesimo quadringentesimo quintodecimo per Ferdinandum Petri de Sancto Petro, notarium publicum Civitatis Cesarauguste, coram notario et testibus infrascriptis in sui prima figura exhibitum et hostensurum et per nos reverenter receptum, cuius tenor talis est.

In Dei nomine. Noverint universi Quod cum, multorum conquestionibus, rumoribus et querimoniis, ad aures Sanctissimi in Christo Patris et Domini nostri Domini Benedicti, divina providentia Pape XIII', nonnulla personam ac vitam et statum domini Fratris Petri Roderici de Moros, Castellani Castellanie Emposte, diocesis dertusensis, ordinis Hospitalis Sancti Johannis Jerosolimitanensis, denigrantia fuissent deducta, idem Dominus noster Papa, considerans quod, inter cetera que suis ex pastoralis officii sollicitudine incumbunt humeris peragenda, illud potissime cordi eius est ut persone ecclesiastice pressertim sub regulari habitu virtutum Domino famulantes recte vivant et secundum eorum Regularis observantie instituta in hiis que ad decorem Religionis pertinent acceptabilem reddant Altissimo famulatum et qui contrarium fecerint debite correctionis disciplina feriantur. Quapropter visitationem et inquisitionem in dicto domino Fratre Petro, Castellano, et eius castris seu cameris ac locis dicte Castellanie faciendam eidemque Domino nostro Pape reportandam et referendam, religiosis viris dominis Fratre 
Enecho de Alfaro et Fratre Paschasio de Morralla, prioris Sancti Johannis Montissoni, Ilerdensis diocesis, ordinis predicti, comissit faciendas cum efectu, prout in litteris apostolicis super hoc confectis, que date fuerunt Dertuse, $\mathrm{XV}^{\circ}$ kalendas febroarii pontificatus eiusdem Domini nostri Pape anno $\mathrm{XIX}^{\circ}$ latius continetur. Et postea inquisitionem continuando predictam per venerabilem virum dominum Michaelem de Lobera, Decretorum doctorem, rectorem de Maella, aliquos testes recipi et ad aliquos actus procedi in Romana Curia et alibi mandavit. Cumque prefati Frater Enechus, Frater Pascasius et dictus Michael visitationem et inquisitionem fecissent supradictas, dictus Dominus noster Papa, motu suo proprio, nobis Johanni, tituli Sancti Laurentii in Damasco, Montisaragonum vulgariter nuncupato, et Petro Sancti Angeli, Cardinalibus Sancte Romane Ecclesie, processum, visitationem et inquisitionem huiusmodi remitentes primo vive vocis oraculo et postea per suam comissionem, manu propria dicti Domini nostri pape signatam, decisionem, determinationem, punitionem atque justitiam super quibuscumque excessibus, criminibus et delictis ac defectibus in dictis processibus contentis auctoritate apostolica comisit cum potestate procedendi atque plenius inquirendi, si nobis videretur expedire, absque quorumcumque terminorum ac cum et cuiuslibet ordinis judiciarii observatione supplendo ex sua certa scientia et plenitudine potestatis omnes defectus tam juris quam facti si qui forsan in dictis processibus tam coram dictis visitatoribus et aliis ad hec deputatis quam coram nobis factis intervenissent quovismodo ordinationibus apostolicis stillo Sacri Palatii Apostolici, juribus, statutis seu stabilimentis et consuetis dicti ordinis ac aliis contrariis non obstantibus. Cumque nos, Cardinales judices et comissarii predciti, cupientes mandata nobis in hac parte directis obedire ac comissionem huiusmodi nobis factam exequi, ut tenebamur, processum, visitationem et provisionem huiusmodi et quedam publica instrumenta et alias scripturas autenticas diligenter inspeximus et examinavimus nedum semel vel bis ac pluries et super contentis in eis digestam et maturam deliberationem inter nos et probos doctores et etiam inter fratres antianos dicti ordinis habuimus. Et nichilominus super quibusdam principaliter contra dictum Fratrem Petrum Roderici de Moros repertis probatis, eumdem Fratrem Petrum ad partem pluries interrogavimus eumque plene, in quantum negotium exhigebat, audivimus, per cuiusquidem confesionem ac responsionem et testimonia, depositiones et alias invenimus ipsum multis culpabilem, propter que, iuxta dicti ordinis stabilimenta et consuetudines atque vota multorum preceptorum et aliorum fratrum antianorum dicti ordinis ad hec per nos iuxta estabilimenta et mores dicte Religionis assumptorum et adhibitorum et ad hec spetialiter convocatorum et super predictis veridice iuxta processus predictorum per nos informatos, ipsis per nos in virtute sancte obedientie interrogatis, reperimus quod dictus Frater Petrus Roderici de Moros debebat perdere habitum et retineri ut strangerius in loco tuto. Unde nos, Cardinales judices et comissarii delegati supradicti, attendentes tenorem et effectus estabilimentorum et estatutorum dicti ordinis, que vidimus et audivimus et super quibus et observantia illorum plenissime sumus informati, considerantes inquam vota predictorum preceptorum et fratrum antianorum et juridispositionem, habito maturo consilio cum probis et expertis jurisperitis ac cum dictis preceptoribus et fratribus antianis, visisque et attentis processibus et aliis predictis ac confessione ipsius Fratris Petri Roderici de Moros et aliis omnibus que circa hec debebamur videri et attendi, die et loco infrascriptis pro tribunali sedentes more judicum judicavimus, solum Deum pre oculis nostris habentes, sacrosanctis quatuor Evangeliis coram nobis positis, ut judicium nostrum de vultu Dei procedat et oculi nostri videant equitatem, ad hoc vocato et presenti dicto Fratre Petro Roderici de Moros et presentibus etiam infrascriptis preceptoribus et fratribus dicti ordinis, nostram difinitivam sententiam ferimus et promulgamus in hiis scriptis, quam statim legi volumus pro 
nobis ac nomine et vice nostris per dictum venerabilem virum dominum Michaelem de Lobera in hunc qui sequitur modum.

Christi nomine invocato. Nos, Johannes, miseratione divina tituli Sancti Laurentii in Damasco, Presbiter, et Petrus, eadem miseratione divina tituli Sancti Angeli, Diachonus, Sancte Romane Ecclesie Cardinales, judices ad infrascripta a Sede Apostolica deputati, pro tribunali sedentes, habentes pre oculis solum Deum, per hanc nostram difinitivam sententiam, quam ferimus in hiis scriptis, pronuntiamus et declaramus vos Fratrem Petrum Roderici de Moros deponendum, amovendum atque privandum fore a Castellania Emposte, ordinis Hospitalis Sancti Johannis Jerosolimitani et a dicta Castellania vos deponimus, amovemus atque privamus, etiam vos privandum esse ab habitu dicti ordinis et a dicto habitu vos privamus, preterea vos retinendum et custodiendum esse in loco securo et taliter vos retineri et custodiri mandamus et ordinamus.

Lata fuit hec sententia per nos, Cardinales judices predictos, et lecta per dictum venerabilem Michaelem de Lobera apud villam Sancti Mathei, dertusensis diocesis, intus palatium ubi dictus Dominus noster morabatur, die tertia mensis Julii anno a nativitate Domini millesimo quadringentesimo quatuordecimo, pontificatus predicti Domini nostri Pape anno $\mathrm{XX}^{\mathbf{0}}$.

Quibusquidem prolationi et lectioni predicte sententie de mandato et ordinatione dicti Domini nostri Pape interfuerunt venerabiles et religiosi viri domini Frater Gundisalvus de Funes, prior Cathalonie preceptorque de Cantavetula et Aliaga, Frater Rodericus de Luna, de Montessono, Frater Jaufridus de Cano, de Uldecona, Frater Enechus de Alfaro, de Ricla et de Enzina Corba, Frater Raymundus de Montcada, de Valentia, Frater Martinus Daymar, de Barbastro, Frater Arnaldus Folquer, de Orta, Frater Johannes de Miedes, de Torrent de Cinqua, Frater Johannes Dusay, de Vilell, Frater Gundisalvus de Boyl, de Saliellas, Frater Huguetus de Pace, de Sancto Michaele de Fozes, Frater Bernardus de Mortier, de Templo Civitatis Hoscensis, Frater Fortunius de Heredia, domorum antiquarum preceptoris, Frater Pascasius Morralla, presbiter, prior ecclesie Sancti Johannis Montissoni, Frater Salvator de Luna, abbas de Alcolea, dicte Castellanie de Emposta. Item Frater Lodovicus de Gualbis, de Villafranca, Frater Johannes de Scarigas, de la Espluga Calva, Frater Raymundus Roguerii de Aril, de Barbant, Frater Johannes Parda, de Turribus, Frater Bernardus Clasquari, de Cervaria, Frater Johannes de Marziella, d'Avinyonet, Frater Guilermus Sicart, de Soteres, Frater Berengarius de Casanova, de Tèrmens, preceptores Prioratus Cathalonie. Item interfuerunt Frater Alvarus de Luna, preceptor de Castellot, Frater Lodovicus de Muro, Frater Johannes de Villafranqua, Frater Raphael Çaplana, Frater Matheus Montull, Frater Martinus d'Archos, Frater Franciscus de Monforti, Frater Gabriel de Galbis, Frater Johannes de Taraçona, Frater Dalmatius Dezcoll, Frater Johannes de Medrano, Frater Petrus d'Avinyó, Frater Petrus Alberti, Frater Martinus d'Ayerbe et Frater Luppus d'Uxone, ordinis Hospitalis Sancti Johannis Jerosolimitani, de quibus omnibus et singulis nos dicti Cardinales judices prefati volumus, requirimus et petimus vobis et aliis quorum intersit fieri et tradi unum et plura publicum et publica instrumentum et instrumenta nostrorum sigillorum appensione munita per Magistrum Franciscum Januarii, notarium infrascriptum, presentibus prenominatis dominis preceptoribus et fratribus ac etiam venerabilibus viris domino Francisco Aranda, donato Porte Celi, ordinis cartusiensis, ac domino Petro Bertrandi, doctore, cive Valentie, pro testibus ad hec vocatis spetialiter et assumptis.

Subsequenter, die eadem et quasi incontinenti nos dicti Cardinales cum dicto domino Fratre Petro Rodrigo de Moros accessimus personaliter ad presentiam dicti Domini nostri Pape in dicto palatio residentis et, intimatis per nos dictos Cardinales omnibus predictis, ex sua solita 
clementia dictus Dominus noster Papa dixit quod ipse restituebat dicto domino Fratri Petro Roderici de Moros dictum habitum, de quo supra per nos per dictam sententiam fuerit privatus. Ceteris in eadem sententia contentis in suo robore duraturis. Mandando expresse eidem Fratri Petro quod ex tunch sequeretur Curiam Romanam et ab ea non recederet absque ipsius Domini nostri Pape spetiali licentia. Que fuerunt acta loco, die, anno pontificatus et presentibus quibus supra.

Sig + num mei Francisci Januarii, presbiteri, dertusensis diocesis, publici apostolica auctoritate notarii Camere Apostolice, qui premisse sententie pronuntiationi, habitus privationi et restitutioni et aliis, dum sich, ut premittitur, per dictum Dominum nostrum Papam ac dictos Reverendissimos Dominos Cardinales dicerentur et fierent una cum prenominatis testibus et aliis interfui. Eaque in hanc publicam formam per alium fideliter redigens scribi feci et sigillorum dictorum Dominorum Cardinalium appensione munita clausi requisitus. Et mea propria manu subscribendo et meum solitum signum apponendo in testimonium premissorum. Constat autem michi de literis in raso positis in lineis II Fratris Petri et alibi in eadem et quatenus et in VII, ubi legitur Curia. Et alibi et in XXVII, ubi dictus et cum dictionibus adictis et in ultima linea scripti, ubi dicitur predictis ac confesione ipsius Fratris Petri Roderici de Moros et aliis.

II

Confirmació pel papa Benet XIII de la sentència emesa pels cardenals jutges $i$ comissaris contra Fra Pedro Roiç de Moros.

ACA, Cancelleria, Processos en volum, 47. Extracte. Any 1414. Plec 102/24, fol. 2 r.v.

Benedictus, Episcopus, Servus servorum Dei, Papa XIII. Dudum siquidem ad audientiam nostram fama publica deferentem deducto quod olim dilectus filius Petrus Roderici de Moros, tunc prior Castellanus nuncupatus prioratus Castellanie nuncupati Hospitalis Sancti Johannis Jerosolimitani de Emposta, dertusensis diocesis, nonnulla delicta, crimina et excessus comisserat ac super hiis auctoritate nostra, debita inquisicione facta, Nos dilectis filiis nostris Johanni, tituli Sancti Laurentii in Damaso, Presbitero ${ }^{88}$, et Petro Sancti Angeli, Diachono ${ }^{89}$, Cardinalibus super huiusmodi excessibus, criminibus et delictis, auctoritate predicta etiam inquirendi et contra ipsum Petrum Roderici de Moros propterea procedendi eumque puniendi ac super hiis justitiam ministrandi comittimus facultatem... Idemque Johannes et Petrus Cardinales in huiusmodi eis comissa facultate procedentes legitimam suam difinitam sententiam inter alia pronuntiarunt, decreverunt et declararunt prefatum Petrum Roderici, suis exhigentibus demeritis a dicto prioratu deponendum, privandum et amovendum fore ipsumque privarunt, deposuerunt et amoverunt penitus ab eodem. Nos, igitur, sententiam ipsam... confirmamus...

Datum apud Sanctum Matheum, dertusensis diocesis, VI idus Julii pontificatus nostri anno vicessimo.

${ }^{88}$ Cardenal Juan Martínez de Murillo, anomenat també Cardenal de Montaragó.

${ }^{89}$ Cardenal Pere de Fonseca. 
Còpia del procés de revisió o apel lació i súplica del Castellà Roiç de Moros al Concili de Constança $i$ al papa Martí $V$.

ACA, Cancelleria, Processos en volum, 47. Plec 106/ 40. Extracte.

A. Copia processus, quod (sic) in Curia Dertusensi, Castellanie Emposte coram Reverendissimo Patre Domino Cardinali Judici et Comissario (ducitur).

[fol. 1 r.] In nomine Domini. Amen. Anno a nativitate eiusdem millesimo quadringentesimo decimoseptimo, indictione decima, die sabbati vicesimatertia mensis octobris, Apostolica Sede pastore carente, in mei notarii publici testiumque infrascriptorum ad hoc spetialiter vocatorum et rogatorum presentia personaliter constitutus discretus vir Franciscus de Mediolano, Apostolice Sedis cursor, ex parte Reverendissimi in Christo Patris et Domini, Domini Johannis, miseratione divina Sacrosancte Romane Ecclesie Cardinalis et Vicecancellarii, quadam comissione sive supplicatione cedulam Reverendissimo in Christo Patri et Domino, Domino Angelo, eadem miseratione titulo Sanctorum Petri et Marcellini, Sacrosancte Romane Ecclesie Presbitero, Cardinali Bononiensi vulgariter nuncupato, judici et comissario, facto realiter et in scriptis, tenoris infrascripti, exhibuit atque presentavit. Qua quidem comissione sive supplicatione cedulam idem Dominus Angelus, Cardinalis, judex et comissarius, [fol. $1 \mathrm{v}$.] de ipsius cursoris manibus reverenter recipiens eamque michi, Johanni Renonburgh de Montemartis, clerico Padeburnensis diocesis, publico Apostolica et Imperiali Auctoritate notario scribeque suo tradidit fideliter.

Tenor dicte comissionis cedule (...) [fol. 2 r.] Reverendissime Pater. Reverendus pater et honestus Religiosus venerabilis frater Petrus Roiç de Moros, Castellanus Amposte, dertusensis diocesis, ordinis et Religionis Hospitalis Sancti Johannis Jerosolimitanensis ante tempus et tempore de undecima die mensis Julii anni a nativitate Domini millesimi quadringentessimi quarti decimi tenens et possidens suam castellaniam cum suis omnibus membris et cum suis cameris secundum statuta et consuetudines Religionis et ordinis predictorum Hospitalis Sancti Johannis Jerosolimitanensis, Dominus Petrus de Luna, Benedictus Papa Tridecimus vocatus in sua obedientia per suos fautores nisus fuit facere suos perversos damnatos processus contra dictum dominum Castellanum honeste ac bone fame, bone vite et conversationis honeste, insons et immunis ab omni crimine, [fol. 2 v.] macula et labe criminis, et non precedente aliqua infamia sed tipo malitie et non justitie, ipso non vocato, non citato neque audito nec in suo jure defenso nec data sibi copia ad eius defensionem dictorum perversorum processuum, licet diligenter petita, quam nunquam potuit habere, ad dandum suas defensiones dictis perversis processibus factis et sic auferendo sibi defensionem, saltem de facto, eidem domino Castellano, datam et permissam a doctrina et sensualitate nature, quam aliquis superior, quantumcumque superioritatem habeat, non potest tollere nec auferre, quia non processit ab aliqua constitutione principum, nisus fuit ex dictis suis nullis perversis processibus de dicto mense Julii et dicti anni millessimi quadringentesimi quarti decimi in villa [fol. 3 r.] Sancti Mathei, dertusensis diocesis, saltem nulliter et de facto pronuntiare diffinitive contra dictum dominum Castellanum privando, prout in eo fuit, ipsum dominum Castellanum dicta sua Castellania et suis cameris, quas habebat 
secundum statuta dicti sui ordinis et super re dubia ferre certam sententiam contra jura divina et humana et contra processum ductum.

Et licet non fuisset, prout nec fuit necesse appellare a dicta perversa sententia diffinitiva propter eius nullitates predictas, nichilominus dictus dominus Castellanus, saltem tacite, videretur eam approbare coram quodam notario publico cum propter metum, qui cadere potuit in quemcumque constantem virum, non ausus fuit publice appellare coram dicto Domino Petro de Luna nec suis perversis comissariis [fol. 3 v. $]^{90}$ undecima dicti mensis Julii et anni predicti appellavit ad Sedem Apostolicam cum suis etiam assuetis protestationibus que salvant jus in futurum Dominusque Petrus de Luna, qui fuit pars formata contraria et Judex in eadem causa, post et contra dictam appellationem atemptando et innovando spoliavit dictum dominum Castellanum sua Castellania (...) et in ea intrusit eius perversa auctoritate, prout intrusus est, fratrem Gundisalvum de Funes, preceptorem de Cantavetula. Et cum dictus dominus Castellanus fuit provisus de dicta sua Castellania per Dominum Petrum de Luna, tunc Benedictum Papam Tertiumdecimum in sua obedientia nominatum, Auctoritate Apostolica, ut per verum Papam, et dicta provisio, secundum Capitula Narbonensia, perinde [fol. 4 r.] habetur ac si per indubitabilem Romanum Pontificem facta fuisset, quibus de causis aliquis inferior judex a Papa, nisi per eius delegatum et Auctoritate Apostolica, non potest de ipsa Castellania nec de questione et perversa privatione nec spoliatione nec de dictis atemptatis et innovatis, nec de causis dicte appellationis ipsius cognoscere secundum Canonica Instituta. Cum omnia facta per dictum Petrum de Luna censeantur facta per verum Papam et Auctoritate Apostolica in sua obedientia secundum dicta Capitula Narbonensia, confirmata per Sacrum Concilium ${ }^{11}$. Et [fol. 4 v.] voluistis quod fieret per prius verbum Domino Magistro de Rodis, quod fuit factum in vestra presentia per procuratorem ipsiusdem Castellani, et post, ipso Domino Magistro et certis dominis fratribus et militibus ab eo deputatis, qui omnes se constituunt partem formatam contra dictum dominum Castellanum, cuius occasione habet ipsos suspectos $(\ldots)^{92}$.

${ }^{90}$ Exposa Roiç de Moros la il·legalitat del procés obert contra ell pel Papa Benet XIII i en dóna el que són, al seu parer, les raons, entre elles la indefensió de 1 'acusat i processat i una por invencible al Papa Luna, que farien nul el procés "a radice" i, per tant, il·legítima i invàlida també la sentència.

${ }^{91}$ Fra Pedro Roiç de Moros apel·la a la Seu Apostòlica, aleshores vacant per la renúncia de Joan XXIII i de Gregori XI i per la deposició de Benet XIII, acusat d 'heretgia i cisma, perjuri i contumàcia, pel concili de Constança. L'apel-lació, una nova apel-lació, la fa aprofitant la humiliació de Benet XIII, desposseït del papat i de l'autoritat suprema de l'Església, confiant així de ser reintegrat amb tots els honors i drets a la Castellania. Una primera apel lació l'havia fet per salvar el dret temps a venir, el dia 11 de juliol de 1414, davant la Santa Seu, essent-ne Papa el mateix Benet XIII, a qui qualifica de "pars formata contraria et judex in eadem causa". Creu Roiç de Moros que amb la nova apel·lació lograrà fer fora de la Castellania el qui considera intrús, el seu successor Fra Gonçalvo de Funes, qui era preceptor de Cantavella.

${ }^{92}$ Roiç de Moros fonamenta la seva possessió legítima de la Castellania en el dret canònic, atès que fou proveït de la dignitat pel Papa Benet XIII gaudint de plena autoritat apostòlica $i$, segons els Capítols de Narbona tot el que ell havia fet com a Papa havia de ser reconegut com a vàlid i també legítim, obrat per un Pontífex Romà indubitat 1 indiscutit. Per això, cap jutge inferior al Papa, si no és que fos delegat per aquest i amb la seva autoritat, no podia tenir competències jurídiques. Els Capítols de Narbona havien estat reconeguts $i$ aprovats pel Concili de Constança i pel papa Martí V. Aquesta és la raó de voler aturar el procés i suspendre la sentència donada pels cardenals contra Roiç de Moros fins que no s'esbrinés de manera certa si 
[fol. 5 r.] Supplicatur igitur humilime et devote pro parte dicti domini fratris Petri Royz de Moros, Castellani prefati, vestre Reverendissime Dominationi quatenus causam et causas omnes antedictarum perversarum privationum et spoliationum tam dicte sue Castellanie [fol. $5 \mathrm{v}$.] quam dictarum suarum camerarum et dicte sue appellationis (...) post et contra dictam perversam sententiam diffinitivam et dictam appellationem ipsius alicui probo et experto viro neutri parti suspecto in Romana Curia, qui non sit de Religione et ordinis predictorum Hospitalis Sancti Johannis Jerosolimitanensis cum habeat ipsos dictos legitime de causis suspectos, et propter potentiam sui adversarii, et quia omnes se constituunt... adversarios et partem formatam contrariam contra dictum dominum fratrem Petrum Roderici de Moros (... $)^{93}$.

[fol. 6 v.] Presentata... et tradita fuit dicta comissionis sive supplicationis cedula Domino Cardinali judici et comissario prefato per cursorem antedictum Constancie, in domo habitationis sue, hora vesperarum vel quasi, sub anno, indictione, die, mense, quibus supra, Apostolica Sede vacante, presentibus ibidem honorabilibus viris magistro Ambrosio de Dardanone, literarum apostolicarum scriptore, et Hanselmo de Rodenberg, clerico Maguntine diocesis, testibus...

[fol. 7 r.v.] Procurator substitutus, Anthonius de Moedra.

Procurator Castellani Amposte, Petri Roiç de Moros, Eximinus Capdet, Decretorum doctor, prior maior ecclesie Sancti Salvatoris Cesaraugustanensis, constitutus in Romana Curia (...)

[fol. 9 r.] Angelus, miseratione divina, tituli Sanctorum Petri et Marcellini, Sacrosancte Romane Ecclesie Presbiter Cardinalis Veronensis vulgariter nuncupati, cause et partibus infrascriptis judex et comissarius spetialiter deputatus, universis et singulis dominis abbatibus, prioribus, prepositis, decanis, archidiaconis, cantoribus, custodibus, thesaurariis, sacristis, succentoribus tam cathedralium quam collegiatarum canonicorum parochialiumque ecclesiarum [fol. 9 v.] rectoribus seu locatenentibus eorumdem, plebanis, viceplebanis, capellanis curatis et non curatis, vicariis perpetuis ceterisque presbiteris, clericis, notariis et tabellionibus publicis quibuscumque per civitatem et diocesim dertusensem et alias ubilibet constitutis... salutem in Domino et mandatis nostris, imo verius apostolicis necnon Sacrosancte Synodo Constanciensi firmiter obedire.

el procés i sentència, en la situació en què es trobaven a la mort de Benet XIII, atemptaven contra els Capítols de Narbona "Et pendenti huiusmodi causa coram predicto Domino Cardinali, intendens SanctitasVestra (Martí V) contentionem predicte cause et considerans justissime... ne huiusmodi contentio fuisset seu venisset contra Capitula Narbonensia in hoc Sacro Concilio Constanciensi confirmata et jurata et per Sanctitatem Vestram approbata, predicto Domino cardinali oracula vive vocis comissit et mandavit in causa predicta supersedere et antequam ad ulteriora procederetur recognosceret et videret si causa predicta agitabatur contra Capitula Narbonensia, et si ita reperiret, prefato Fratri Petro silentium perpetuum imponeretur " (ACA, lligall 47 , plec $106 / 40$, fol. $138 \mathrm{r}$.)

${ }^{93}$ Roiç de Moros demana per veu del seu representant a la Seu Apostòlica, aleshores vacant, que el procés sigui posat en mans d'un jurista competent i neutral de la Cúria Romana, que no sigui de l'Orde de l'Hospital, perquè el Castellà considera suspectes de parcialitat tots els membres de l'orde esmentat, i aquest jurista revisi el procés, examini les apel lacions i pugui així esmenar, si fos procedent, la sentència del tribunal de Benet XIII. 
Noveritis quod nuper Reverendissimus in Christo Pater et Dominus, Dominus Johannes, miseratione divina Episcopus Ostiensis ${ }^{94}$, Sancte Romane Ecclesie Cardinalis et Vicecancellarius auctoritate dicte Synodi, quandam comissionis sive supplicationis cedulam nobis per certum Apostolice Sedis cursorem presentari fecit huius sub tenore.

[Aquí (fols. 10 r.- 14 r.) es reprodueix íntegre el text de la súplica i apel lació de Roiç de Moros recollit més amunt en aquest mateix document en els folis 1 v.-15 r.]

[fol. 15 r.] Nos, igitur, Angelus, Cardinalis judex et comissarius..., attendens requisitionem huiusmodi fore iustam et consonam rationi volentesque in causa et causis huiumodi rite et legitime procedere ac partibus ipsis, dante Domino, justitiam ministrare, ut tenemur, Auctoritate Apostolica necnon dicte Synodi, vos omnes et singulos supradictos... tenore presentium requirimus et monemus primo, secundo, tertio et peremptorio termino vobisque nichilominus et vestrum cuilibet in virtute sancte obedientie et sub excomunicationis pena, quam in vos et vestrum quemlibet, si ea que vobis in hac parte comittimus et mandamus neglexeritis seu distuleritis contumaciter adimplere, canonica monitione premissa, ferimus in his scriptis, districte precipiendo [fol. $15 \mathrm{v}$.] mandamus quatenus infra sex dierum spatium post presentationem seu notificationem presentium vobis seu alteri vestrum factas in medietate sequenti et postquam pro parte dicti fratris Petri Roys, principalis, fueritis requisiti seu alter vestrum fuerit requisitus. Ita tamen quod in hiis exequendis unus vestrum alterum non expectet nec unus pro alio se excuset. Quorum sex dierum duos pro primo, duos pro secundo et reliquos duos dies vobis universis et singulis pro tertio et peremptorio termino ac monitione canonica prefigimus et assignamus prefatum Gundisalvum ex adverso principalem omnesque alios et singulos supradictos in eorum propriis personis si ipsorum presentias comode habere poteritis, alioquin in hospiciis habitationum suarum si ad ea intus pateat accessus. Et in parochiali seu parochialibus, sub qua vel quibus [fol. $16 \mathrm{r}$.] degunt et morant, et ecclesiis, sin autem in eisdem ac Cathedrali dertusensi aliisque ecclesiis et locis publicis infra missarum solempnia, dum ibidem populi multitudo ad divina audiendum vel alias congregata fuerit... [fol. $16 \mathrm{v}$.] mandamus quod omnes et singulos supradictos ex parte nostra, ymo verius, Apostolica et dicte Synodi Auctoritate, publice, alta et intelligibili voce peremptoria, citare curetis... quatenus quinquagesima die die post citationem vestram... alioquin prima die juridica ex tunc immediate sequenti, qua nos vel predictum forsan judicem surrogandum Constancie vel alibi, ubi tunc forsan Romana Curia residebit, in domibus solite nostre residentie, hora vesperorum consueta ad jura reddendum in loco suo solito et consueto pro tribunali sedere contigerit, compareant in juditio. [fol. 17 v.] (...) eadem Auctoritate Apostolica et Concilii predicti comittimus et mandamus quatemus post legitimam dicte citationis executionem Reverendo in Christo Patri et Domino, Domino Episcopo dertusensi eiusque in spiritualibus et temporalibus vicario et officiali necnon Gundisalvo de Funes ex adverso principali et omnibus aliis..., quorum interest, intererit et interesse poterit...[fol. $18 \mathrm{r}$.] inhibeatis, quibus nos etiam tenore presentium inhibemus, ne ipsi seu eorum alter in causa huiusmodi in nostre jurisdictionis ac litis pendentis vilipendium et contemptum et dicti domini Petri, principalis perjuditium...

Datum et actum Constancie, provintie Maguntine... sub anno a nativitate Domini millesimo quadringentesimo decimo septimo, indictione decima, die vero Sabbati vicesimatertia mensis octobris, Apostolica Sede vacante, [fol. 19 r.] presentibus ibidem discretis viris magistro

${ }^{94}$ Cardenal Joan de Bronhiac o de Brugniac. 
Ambrosio de Dardanono, literarum apostolicarum scriptore, et domino Wuilhelmo Yvonis, presbitero, Ramierensis diocesis, testibus.

Ego Johannes Renenborgius de Montemartis, clericus Paderburnensis diocesis, publicus Apostolica et Imperiali Auctoritate notarius.

B. [fols. 28 v.- 32 r.] Document de nomenament de procurador de Fra Pedro Roiç de Moros a favor de "Eximinum Capdet, Decretorum doctorem, priorem majorem Ecclesie Beati Salvatoris Civitatis Cesarauguste". "Actum in Civitate Dertuse, decima septima die mensis februarii anno a nativitate Domini millesimo quadringentesimo decimo septimo. Signum Fratris Petri Roiç de Moros. Testes Venerabilis Nicolaus Ester, civis Dertuse, el Lupus Ferdinandi de Cetina, scutifer dicti domini fratris Petri. Signum Petri Miralles, notarii publici Dertuse."

IV

Notícia del conclave de Constança i elecció del papa Martí $V$, integrada en el procés de Fra Pedro Roiç de Moros.

ACA, Cancelleria, Processos en volum, 47. Plec 106/40, fols. 34 r.-35 v.

[fol.34 r.] Introitus conclavis.

Anno et indictione, quibus supra ${ }^{95}$, die Lune octava mensis Novembris, Reverendissimi in Christo Patres et Domini, miseratione divina Sacrosancte Romane Ecclesie Cardinales, in Civitate Constanciensi existentes, una cum deputatis quinque nationum intrarunt conclave ad Summum Pontificem eligendum ${ }^{96}$.

Die Jovis, undecima mensis Novembris predicti, que fuit dies festivus Sancti Martini Episcopi, reverendissimus in Christo Pater et Dominus, Dominus Oddo, miseratione divina tituli Sancti Georgii ad Velum Aureum Sacrosancte Romane Ecclesie Diaconus Cardinalis de

${ }^{95}$ Any 1417, indicció 10 .

${ }^{96}$ Cardenals que van participar en el conclave 1) d'obediència romana. D'Urbà VI Luigi Fieschi, Rinaldo Brancaccio i Ángelo de Summaripa; d'Innocenci VII Giordano Orsini i Odo Colonna (Martí V); de Gregori XII Antonio Correr, Gabriel Condulmer, Giovanni Dominici i Ángelo Malpighi.

2) d'obediència avinyonesa De Climent VII Amé de Saluces, Pedro Fernández i Jean de Brogny; de Benet XIII Antoni Chalant. 3) pisans, promoguts tots per Joan XXIII Branda de Castiglione, Lucido Conti, Francesco Lando, Alamando Ademar, Antonio Panciario, Tomasso Brancaccio, Guillem Fillastre, Pere de Foix, Pierre d'Ailly i Simon de Cramaud.

Representants de les nacions 1) Alemanya els arquebisbes de Riga i Gniezno, el bisbe de Trau, un canonge de Viena, Lambert de Stipite i Konrad von Soest. 2) Espanya Diego de Anaya, Felip de Malla, Blasco Hernández, Gonzalo García de Santa María i els bisbes de Badajoz i Dax.

3) França Jean de Rochetaillée, els arquebisbes de Bourges i Tours, el bisbe de Ginebra, 1 'abat de Cluny i un frare hospitaler. 4) Anglaterra els bisbes de Londres, Norwich, Bath i Lichfield, el degà de Yotk i l'abat de Santa Maria de York. 5) Itàlia Iacopo Turco, Leonardo de Firenze, l'arquebisbe de Milà, els bisbes de Melfi i Belluno i l'ardiaca de Bolonya. Havien entrat, doncs, en conclave 53 persones 23 cardenals i 30 representants de les nacions, sis per cadascuna. 
Calumpna [fol. 34 v.] vulgariter nuncupatus, fuit electus et assumptus in Summum Pontificem et voluit vocari Martinus Quintus ${ }^{97}$.

Die dominica, vicesima prima mensis Novembris, Sanctissimus in Christo Pater et Dominus noster Martinus, divina providentia Papa Quintus, Constancie, ante maiorem ecclesiam, in loco ad hoc ordinato per Reverendissimum in Christo Patrem et Dominum, Dominum Amedeum, Sacrosancte Romane Ecclesie Diaconum Cardinalem Salutiarum vulgariter nuncupatum, fuit solempnissime coronatus.

Pontificatus Sanctissimi in Christo Patris et Domini, Domini Martini, divina providentia Pape Quinti anno primo, die Jovis, vicesima quinta mensis Novembris predicti, de mandato dicti Domini nostri Pape intimata fuit universis et singulis dominis judicibus et comisariis ac Sacri Palatii Apostolici causarum auditoribus ut omnes et [35 r.] singulas causas Apostolica vel Sacri Generalis Constantiensis Consilii Auctoritate eis comissas et coram eis pendentes indecisas in eo statu in quo ultimate coram eis remanserant resumerent et in illis procederent ad ulteriora prout... in quadam papiri cedula Reverendissimi in Christo Patris et Domini, Domini Johannis, miseratione divina Episcopi Ostiensis, Sacrosancte Romane Ecclesie Cardinalis et vicecancellarii... [fol. 35 v.] Datum Constancie, die vigesima quinta mensis Novembris anno a nativitate Domini millesimo quadringentesimo decimo septimo.

Nota. El papa Benet XIII, refugiat i ailllat a Peníscola, on defensà la seva legitimitat fins a la mort, expirava el dia 23 de maig de 1423, data que considerem la més probable, acompanyat dels seus quatre cardenals fidels, creats el 27 de novembre de 1422 durant una gravíssima malaltia del papa Luna, que alguns han considerat efecte recidivant de l'enverinament del pontífex causat pel juliol de l'any 1418, acció criminal atribuïda a un complot dirigit pel legat de Martí V, Alaman de Ademar. No sembla, però, haver-se pogut demostrar ni l'enverinament ni la responsabilitat del legat. Els cardenals creats eren Dominique de Bonnefoi, cartoixà de Montalegre; Julià de Loba, exrector de Batea i clergue de la Cambra Apostòlica en funció de camerlenc; Ximèn Dahe, auditor de la Cambra Apostòlica en funció de penitencier; i Jean Carrier, col-lector i vicari general de Benet XIII als estats del comte d'Armagnac.

Julià de Loba i Simó de Prades redactaren algunes cartes papals dels anys 1421 a 1423 amb l'expressió "Scripta in archa Noe" o amb aquesta altra "Scripta in domo Dei, ubi est vera Ecclesia", en lloc del topònim "Peniscole" com apareix en les butlles pontifícies. La convicció de la legitimitat era, com es veu, ferma i indestructible.

Amb els nous cardenals era garantida la continuació del Cisma d'Occident malgrat el Concili de Constança i l'elecció de Martí V. Així, a la mort de Benet XIII, notícia que va ser amagada durant uns mesos, els cardenals esmentats -llevat de Jean Carrier, qui era a França, i Gil Sanxis Munyós, creat cardenal pocs dies abans de la mort del Pontífex-, reunits en conclave al mateix castell de Peníscola, a la sala que hi ha al costat de la capella castral, l'anomenada Aula dels Paraments, van elegir successor el canonge de la seu de Terol Gil Sanxis

${ }^{97} \mathrm{El}$ cardenal Odo Colonna va obtenir en principi els vots de vuit cardenals dels vint-i-tres que participaven amb veu i vot al conclave, i setze vots dels representants de les nacions un vot de França, dos d'Espanya, tres d'Alemanya, quatre d'Itàlia i sis d'Anglaterra. Després va captar els vots d'altres cinc cardenals $i$, a més, la unanimitat espanyola i alemanya; finalment va rebre els vots de la major part del col·legi de cardenals i, a darrera hora, el suport de França, la nació més negada a donar-li vots. 
Munyós, qui va prendre el nom de Climent VIII. Alfons el Magnànim, òbviament per motius polítics, apartant-se de les ordres procedents de Martí $\mathrm{V}$, donà suport al nou papa de Roma $\mathrm{a}$ Peníscola i ordenà als bisbes i clergues de la Corona d'Aragó de reconèixer Climent VIII i obeir les seves ordres. Als regnes hispànics, Martí V trobava el suport a Castella i en el rei Joan II; Climent VIII el trobava a la Corona d'Aragó i en el rei Alfons el Magnànim. Hi havia encara divisió i dues obediències.

Martí V envià als regnes hispànics, a Alfons el Magnànim i a la cort papal de Peníscola, com a "legatus a latere", el cardenal Pere de Foix per tal d'aconseguir l'acabament definitiu del Cisma d'Occident amb l'abdicació de Climent VIII. Entrà en acció en aquell moment el morellà Francesc Rovira, canonge de la Seu de Mallorca, conseller del rei i promotor de la cort reial a Aragó, amb la seva gran habilitat política i diplomàtica. Les gestions dun i altre tindran èxit finalment.

El 26 de juliol de 1429, reunits els cardenals i la cort papal a l'Aula dels Paraments, Climent VIII, revestit de pontifical, va celebrar un consistori solemne en presència dels ambaixadors del rei. Abans d'abdicar, va voler, de manera intel-ligent i sàvia, exercir el seu poder papal creant dos nous cardenals per demostrar davant l'Església universal quina era la seva convicció d'autoritat legítima i el poder real, autèntic i legítim de successor de Pere que l'assistia, contra les acusacions públiques dels seus enemics i del mateix Martí V, que l'acusaven d'intrús i farsant. Encara més, va exigir als ambaixadors del rei, que tenien el reconeixement del legat Pere de Foix, que, sota amenaça de no renunciar a la dignitat papal, li reconeguessin i aprovessin la decisió. I tots hi van accedir. Així, doncs, Climent VIII va crear cardenals Francesc Rovira, de l'obediència de Martí V, amb el títol de Sant Climent, i el seu nebot homònim i canonge de Girona, Gil Sanxis Munyós, amb el títol de Santa Maria in Cosmedin, nomenaments que tots dos van acceptar. El cardenal Francesc Rovira lligava en la seva persona les dues obediències i això augurava una imminent i segura fi del Cisma.

En efecte, el mateix dia, immediatament després del consistori, es van reunir en conclave els tres cardenals, Julià de Loba, "Cardinalis Ostiensis", Francesc Rovira i Gil Sanxis Munyós, i, havent celebrat la missa de l'Esperit Sant, tancats i guardats dins la Sala dels Paraments, van elegir "per viam Spiritus Sancti, nemine discrepante" el Cardenal Odo Colonna, anomenat en la seva obediència Martí $\mathrm{V}$, fent-ne aixecar acta pública i notarial a l'escrivà Bernat Torvet, signada pels cardenals electors i els ambaixadors reials, "spetialiter ad hoc vocati et rogati". Acte seguit, el papa Climent VIII va abdicar "per viam renuntiationis", va proclamar l'obediència a Martí $\mathrm{V}$ i va subscriure també l'acta manifestant solemnement les seves intencions, mòbils, estratègia i decisió: Que ell havia acceptat l'elecció pontifícia feta pels cardenals de Benet XIII, el seu predecessor, només per poder tenir l'honor de ser ell qui posés fi a un cisma tan dolorós i restituir la unió i la pau a l'Església de Jesucrist mitjançant la seva renúncia, i que aquesta havia estat la seva intenció honesta des del moment de la seva elecció. Si abans hagués estat possible de fer-ho sense coaccions i amb plena llibertat, abans ho hagués fet, com ho feia aleshores perquè posseïa la llibertat necessària, perquè en cap moment no havia dubtat que la seva renúncia seria, com ho era, la via més breu i segura d'aconseguir la unió de l'Església.

I Climent VIII va despullar-se de les vestidures papals. 
El 15 d'agost, festa de l'Assumpció de la Verge Maria, a l'església de Sant Mateu del Maestrat, el Cardenal legat, Pere de Foix, va celebrar una solemne missa pontifical en acció de gràcies per l'acabament definitiu del Cisma d'Occident ${ }^{98}$.

\section{ALTRES DOCUMENTS}

A. Cèdula de suplicació de Roiç de Moros contra Gundisalvo de Funes per tal que hom declari aquest detentor intrús de la Castellania d'Amposta "dicte Castellanie Emposte illicitum detentorem et intrusum". Plec 106/40, fols. 37r.-38r.

B. Nomenament de procurador especial de Fra Pedro Roiç de Moros a favor de P "honorabilem Egidium Roderici de Moros, clericum diocesis Cesaraugustanensis". Tortosa, 11 d'agost de 1416. Testimonis "Nicolaus Ester, civis, et discretus Petrus Bages, presbiter Dertuse". Plec 106/40, fols. 39 v. -43 r.

C. Nomenament de substituts per part de Gil Roiç de Moros a favor dels "venerabiles viros magistros Johannem Nicolai et Johannem de Ponte, transferens in illos potestatem omnimodam..." Data 8 de desembre de 1417. Plec 106/40, fol. 43 r.v.

D. Compareixença en judici i presentació dels documents de procura pels procuradors de Fra Gundisalvo de Funes, Castellà d'Amposta: "Comparuit in juditio coram Domino Cardinali judice Constancie, in domo habitationis sue, hora vesperarum... Magister Johannes de Scribanis", procurador de Fra Gundisalvo de Funes, presentant les lletres de la seva procura: "Anno a nativitate Domini millesimo quadringentesimo decimo septimo, die vigesima quinta mensis Novembris, apud castrum loci de Azquo personaliter constitutus multum Reverendus Dominus Frater Gundissalvus de Funes, ordinis Hospitalis Sancti Johannis Jerosolimitanensis, dignus Castellanus Emposte", nomenà procuradors seus davant la Cúria Romana "Fratrem Johannem de Mayrons, procuratorem generalem ordinis Hospitalis, Magistrum Johannem de Scribanis, Henricum de Pino, Jacobum de Francenquis, Johannem Nicolai, Petrum Eloeti, in Romana Curia procuratores, et Leonardum de Tosqua, notarium, habitatorem ville Alcanicii".

Data: Divendres, 14 de gener de 1418. Plec 106/40, fols. 50 r.- 55 r.

E. Atorgament de poders de procura per part de Fra Fernando de Funes:

"Apud castrum de Miravet, diocesis dertusensis, personaliter constitutus multum honorabilis et honestus religiosus vir Dominus Frater Ferdinandus de Funes, ordinis Hospitalis, preceptor sive comendator de Mallen... Testes Anthonius Remmirez, scutifer, et Frater Johannes de Lynayn, ordinis Hospitalis, de domo Reverendi Castellani Emposte". Data 17 de desembre de 1417. Plec 106/40, fols. 58 v.- 63 r.

${ }^{98}$ Manuel Milián BoIX, Postrimerías del Cisma de Occidente Francisco Rovira Escuder, pp. 31, 35-36, 45-47. Ricardo GARCía VILLADA (direcc.), Historia de la Iglesia en España, III- ${ }^{\mathrm{a}}$, pp. 34-43, 53-64. 
F. "Capitula Narbonensia". Text de les capitulacions de Narbona. Plec 106/40, fols. 157 r.- $161 \mathrm{v}$

G. Butlla del papa Martí V amb la sentència emesa sobre l'afer de la Castellania d'Amposta, adreçada al gran mestre i capítol general de l'Orde de l'Hospital. Plec 106/40, fols. 157 r.- $161 \mathrm{v}$.

El papa Martí V, vist el procés i el seu estat, dóna tota la llicència canònica necessària per cloure el procés i intima els responsables de l'Orde de l'Hospital que "vocatis dicto Petro et Gundissalvo et aliis qui fuerint evocandi, causam huiusmodi juxta stabilimenta et consuetudines supradicta huic debito, omni appellatione remota, terminare seu terminari facere nullatenus postponatis, super quo vobis plenariam tenore presentium ex habundante cautela concedimus potestatem". La sentència es troba en butlla dirigida a "Philiberto, Magistro, et Capitulo generali fratrum Hospitalis Sancti Johannis Jerosolimitanensis, Avinioni proxime celebrando... Datum Geben, kalendis Julii, pontificatus nostri anno primo."

1417, octubre, 30. València.

Carta del rei Alfons el Magnànim dirigida als ambaixadors seus enviats al concili de Constança en què, havent estat privat de la Castellania d'Amposta fra Pedro Roiç de Moros pel papa Benet XIII $i$ nomenat nou Castellà fra Gundisalvo de Funes, accions legítimes $i$ vàlides de ple dret en virtut de la validesa reconeguda als capitols de Narbona, els ordena de fer tot el que sigui en llur poder davant el concili i el papa que en pugui sorgir, també davant l'emperador Segismund i el mestre de Rodes, per tal que no sigui admès el recurs de Roiç de Moros.

ACA, Cancelleria, reg. 2702, fol. 93 r.

Lo Rey d'Aragó e de Sicília, etc. Embaixadors, segons ja sabets e per altra nostra letra vos havem scrit, olim Papa Benet ab sentència diffinitiva amogué frare Pere Roiz de Moros, Castellà qui era d'Amposta, e abans la substracció provehí de la dita Castellania lo venerable religiós e amat nostre frare Gonçalvo de Funes. E com haiam entès que lo dit frare Pere Roiz haia tramès aquí per sublevar la dita causa ab colors e maneres exquisides, e la dita provisió feta en persona del dit frare Gonçalvo axí com feta abans la primera requisició sia segons lo tenor dels capítols celebrats a Narbona vàlida e ferma. E d'açò scriscam al Rey dels Romans e al Mestre de Rodes remettents creença a vosaltres, vos dehim, manam e encarregam que sobre les dites coses tengats a prop e avisets axí lo papa únich sdevenidor e concili com los dits Rey dels Romans e Mestre de Rodesm embargants, tant com en vosaltres sia, lo dit frare Pere Roiz no sia admès. Car nos no tolleraríem ni daríem paciència que al dit frare Gonçalvo fos perjudicat en dita provisió. E en açò vos haiats axí sàviament e diligent com de vosaltres confiam. Certifficants vos quens en farets plaer e servir molt agradables e del contrari hauríem gran desplaer. 
Dada en València sots nostre segell secret a XXX dies d'octubre de l'any de la nativitat de nostre Senyor M CCCC XVII. Rex Alfonsus.

Dominus rex mandavit mihi Paulo Nicholai.

Probata.

*Agraeixo al Prof. Fernando Pérez-Ordoyo la versió en anglès del Sumari. 